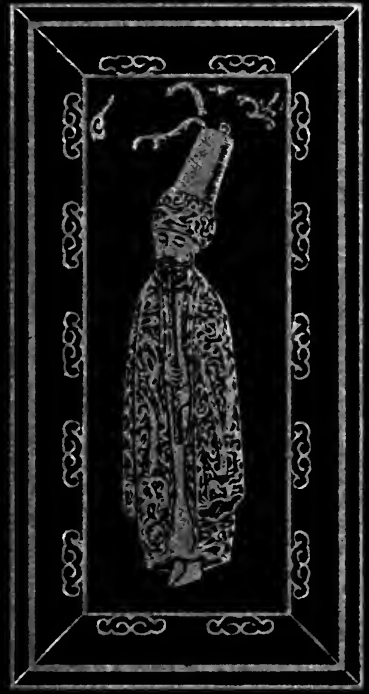


$a^{2} C^{6^{2}}$
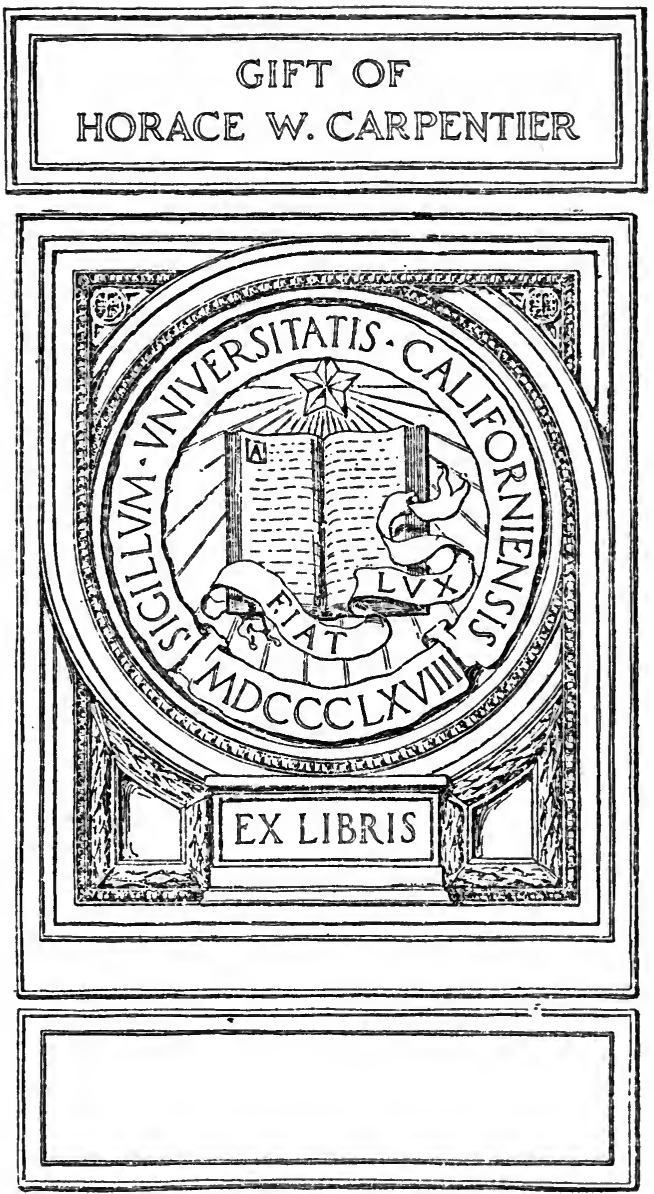

jot 


\section{THE CITY OF \\ DANCING DERVISHES}




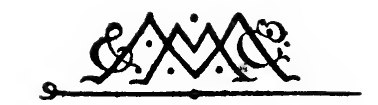

\author{
MACMILLAN AND CO., Limited \\ LONDON - BOMBAY - CALCUTTA \\ MELBOURNE
}

THE MACMILLAN COMPANY

NEW YORK - BOSTON - CHICAGO

DALLAS - SAN FRANCISCO

THE MACMILLAN CO. OF CANADA, Ltd. TORONTO 
Digitized by the Internet Archive in 2008 with funding from Microsoft Corporation 


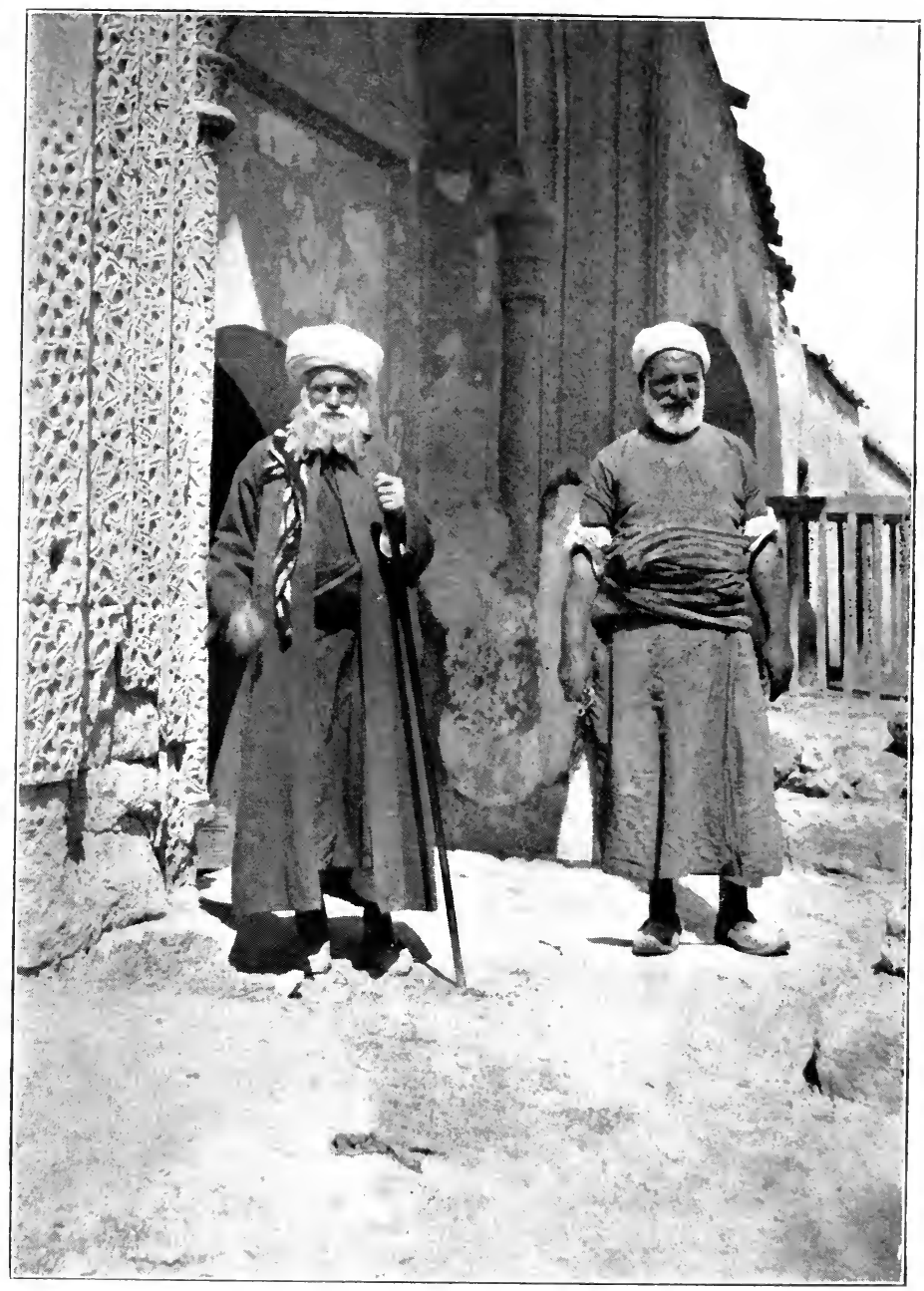

OUTSIDE THE MOSQUE OF SAHIB 'ATA, KONIA. 


\section{THE CITY OF}

\section{DANCING DERVISHES}

AND OTHER SKETCHES AND STUDIES FROM THE NEAR EAST

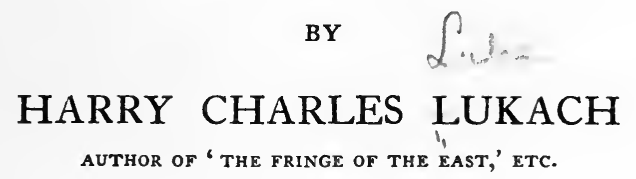

ILLUSTRATED WITH PHOTOGRAPHS

TAKEN BY THE AUTHOR

MACMILLAN AND CO., LIMITED ST. MARTIN'S STREET, LONDON 


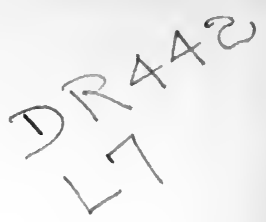

COPYRIGHT

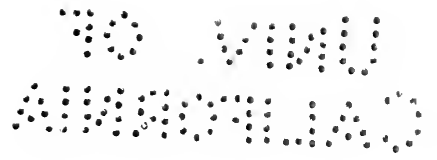


To

LADY GOOLD-ADAMS

\section{6}





\title{
PREFACE
}

OF the following sketches and studies, the first, the fifth, and a portion of the second have appeared in The Morning Post, the third in The Fortnightly Review, the sixth in The Times, the seventh (under a different title) in Blackwood's Magazine, the eighth and tenth in The Near East; and I am indebted to the editors of these periodicals for their kindness in allowing me to reproduce them here.

For permission to include $S$. Andrew the Miracle-Worker I have also to thank Mrs. A. K. Bovill, in collaboration with whom it was written.

\section{H. C. LUKACH.}

\author{
Nicosia, \\ November I9I4.
}





\section{CONTENTS}

PAGE

I. The City of Dancing Dervishes • - 3

II. The Khoja of Aqshehir $\quad$ - $\quad$ - $\quad$ - 37

III. SOME ASPECTS OF ISLAM IN TURKey • • 79

IV. The TURKish Khalifate aNd its ORigin • IOI

V. The Last Days of a Grand Vizier . . 127

VI. At an OPENing of the Legislature of

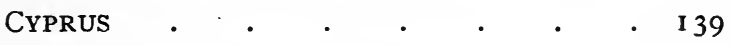

VII. S. ANDREW THE MiRACLE-WORKER . . I 47

VIII. Of Priests AND Patriarchs • • • 173

IX. The False Messiah • . . . . 185

X. The Passing of the Picturesque - . 249 



\section{ILLUSTRATIONS}

FACING PAGE

Outside the Mosque of Sahib 'Ata, Konia - Frontispiece Interior of the Mosque of Sultan Ala'u'd-Dîn, Konia . Io

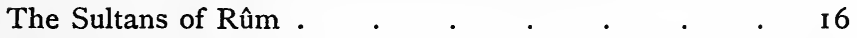
The Chelebi of Konia $\quad$. . . . . 20

A Mevlevi Adept playing the Flute. From an old Turkish miniature $\quad . \quad$. $\quad . \quad$. 26 The Dancing-floor of a small Tekyé . . . . 26 The Mevlevi-Khané, from a Minaret of the Selimîyeh Mosque . . . . . . . . . 30 The Tomb of Khoja Nasr ed-Dîn, Aqshehir . . 40 The Khoja's Grave . $\quad$. . . . . 48 The Dash Medresé, Aqshehir . . . . . . 60 A Dervish Mausoleum . . . . . . 86 Kiamil Pasha in Cyprus . $\quad . \quad$. $\quad . \quad$ I 32 Maria and Panteli . $\quad . \quad . \quad . \quad . \quad . \quad 158$ 



\section{I \\ THE CITY OF DANCING DERVISHES}





\section{THE CITY OF DANCING DERVISHES}

I

To one who had not travelled in the interior of Turkey since the revolution of 1908 the absence, on landing at the port of Mersina, of the vexatious formalities so dear to the old régime was eminently refreshing. The close scrutiny of one's passport, not infrequently held upside down by suspicious functionaries, the achievement of a tezkere, or local passport for the Turkish provinces, which had to be vise, at a price, as one entered each separate vilayet, the demand for detailed and intimate personal information presented on a formidable questionnaire, these and similar sources of worry were no more. With a polite "Buyuruñ, Effendim," 
I was bowed past the Harbour Police Office, a fortress not easily stormed in the days of 'Abdu'l Hamid.

I had arrived from Cyprus, and my object was to reach Smyrna by way of Konia, once the capital of the Seljuq Sultans and still the headquarters of the Mevlevi Order of (Dancing) Dervishes, and Aqshehir, the home of Turkey's greatest jester, the Khoja Nasr ed-Din. Toward the end of I9I5, the Vali of Konia told me, the Baghdad Railway, after tunnelling through the Taurus, will reach Adana, on the Mersina-Adana Railway, and thus enable the journey I was undertaking to be performed entirely by rail; at present railhead is a spot called Kara Punar (Black Spring), on the northern slope of the Taurus, leaving a gap of about 50 miles over the mountains to be negotiated by carriage.

The Adana Railway traverses the rich plain that lies at the southern foot of the Taurus, running through miles of fields of the cotton, whose cultivation is the principal industry of the vilayet. Cotton and cotton seed are plentifully exported ; labour, too, is plentiful, and is drawn from the unattractive mixture of races which 
compose the population. In the vilayet of Adana Turks are comparatively rare, especially in Mersina and its neighbourhood; most numerous are probably the fellahîn, Arabicspeaking descendants of Egyptian immigrants who settled in the district some generations ago. There is also a large Syrian community (in Mersina the predominant language is Arabic), there are gypsies, there are nomad Yürüks, there is even an East Indian element; while in the towns there are important communities of Greeks and Armenians, the latter slightly thinned, as regards Adana, in I909! I was forcibly impressed, in the course of this journey, by the rudeness manifested towards strangers by the lower classes of town-bred Armenians, a condition of things unknown before the revolution had freed them of past restraint.

I left the railway at Tarsus, whence the old caravan road sets forth across the pass of the Cilician Gates. Tarsus is a town of about 20,000 inhabitants, largely composed of Greeks and Armenians, and it endeavours to redeem something of its squalor by electric lighting. The remains of "S. Paul's Gate," of Roman 
construction, and the so-called "S. Paul's Well" alone preserve associations with its most renowned citizen; its sole amenity lies in a broad crescent of verdure-gardens of almond, orange, and mulberry trees-which encompasses it on the east. Here I obtained a yailieh, one of those long, barrel-shaped, seatless Turkish carriages which, when their blinds of black oilcloth are drawn, resemble coffins on wheels; and tried, but failed, to find comfort with the help of baggage and rugs. My driver was an Anatolian Greek, who knew no word of Greek except his name, which was Charálampos; for most of the Greek villagers of the interior of Asia Minor speak no language but Turkish, in which even the services of the church are sometimes celebrated, although you may occasionally find an erudite person who writes Turkish in Greek characters.

We drove through the night, and at dawn reached the "Gates" of the pass, two mighty walls of rock on whose surface some ancient conqueror, Alexander the Great, perhaps, has commemorated his passage by inscriptions now undecipherable. The pass is only wide enough for river and road, but beyond it one enters into a 
wide expanse of beautiful Alpine scenery where verdant valleys seem to lose themselves in all directions among the forest-clad mountains. As we drove down to the railway we encountered endless strings of caravans coming slowly towards us. They belonged to Turkish villagers from the plain who had been spending the hot months in their yaila, or summer station, in the mountains, and were now returning home at the approach of cold, with their families and herds of undersized but hardy cattle.

They all seemed to bear a strong resemblance to one another, these Cilician Turks, with their rather long noses, thin lips, small, keen eyes, and closely trimmed beards. The women wore full black trousers and were unveiled; the hair of many of them was stained red with henna. The men rode sturdy little Anatolian ponies; women and children were on donkeys scarcely bigger than goats, or walked; babies were packed in crates carried by camels. The camels, with the brown Yürük saddle-bags in which theirowners' household goods are packed, and their bright Kurdish rugs, were delightfully picturesque; and at every movement evoked lovely sounds from their deep-toned bells. 
At Bozanti, about seven miles from Kara Puñar, the road joins the railway, which soon leaves the mountains for the bare plateau of central Anatolia. Here mile upon mile of cultivable but uncultivated land would appear to offer a splendid asylum for refugees from Macedonia ; but, instead of being repeopled, the country was being drained, for a time, at all events, of much of the manhood which it possessed. From every station which I passed between Bozanti and Smyrna recruits were being collected and despatched to the headquarters of the main Turkish Army in Thrace; and I witnessed many a sight of poignant pathos as lean old sergeants in tattered uniforms, some wearing putties and slippers, others with aiguillettes of yellow cord fastened with safety-pins to where their shoulder-straps should have been, tried to marshal their squads into the train, or with rough kindliness to cut short harrowing farewells from aged mothers about to lose their only support. At one station a sturdy lad of the name of 'Alî was being seen off by a host of relatives. 'Ali's old father and venerable grandfather, grizzled peasants, who had once, no doubt, been through the same business them- 
selves, his brothers and little nephews, were clustering around him, adjuring him to take care of himself, and to write soon. Behind the men stood four old women, crying as if their hearts would break, and wiping their tears with the ends of the charshaf with which they covered their wrinkled faces, as they besought Allah to grant the boy a safe return. The least affected of the party was 'Alt himself. "Insha'llah," " if God will," and "aghlama," "don't cry," was all he said; and soon after we left the station I saw him sitting in the next carriage to mine, contentedly eating cheese and grapes with his new companions. But I shall not soon forget the despairing wail of the old women as the train steamed slowly away.

Half-way between Bozanti and Konia is Karaman, once the capital of a Turkish dynasty which has given its name to the town and to all the southern coast of Asia Minor. On an eminence behind the station stands its picturesque mediæval castle; on the station platform itself some Khojas were making their mid-day namaz. ${ }^{1}$ Late in the evening, past gardens and plantations, the train steamed into Konia;

1 The five daily prayers obligatory on all Moslems. 
and the handsome modern station offered the interesting sight of an officer trying to collect together his band of ragged conscripts, while fierce Bosnians and Albanians squatted and smoked with a group of prisoners chained heavily by the neck, and spectacled old Dancing Dervishes sought anxiously for their carpet bags in the van.

II

Konia, the ancient Iconium, possesses two claims to fame which place it in a category apart from all other large towns of Asia Minor, and render the fact that it is the capital of an extensive vilayet relatively unimportant. During a flourishing epoch which endured from the end of the eleventh to the beginning of the fourteenth century it was the nucleus of a brilliant independent state, the seat of the Seljuq Sultans of Rum ; ${ }^{1}$ and has preserved from its Seljuq Sultans, pre-eminent among rulers of Turkish race as patrons of art, a series of monuments from whose crumbling tiles and decaying porticos there still flickers a spark of the departed

1 The Seljuq Sultanate of Konia was called Rtum (Rome) because it was conquered from the Byzantine Empire, which never ceased to maintain the fiction that it was Roman. 


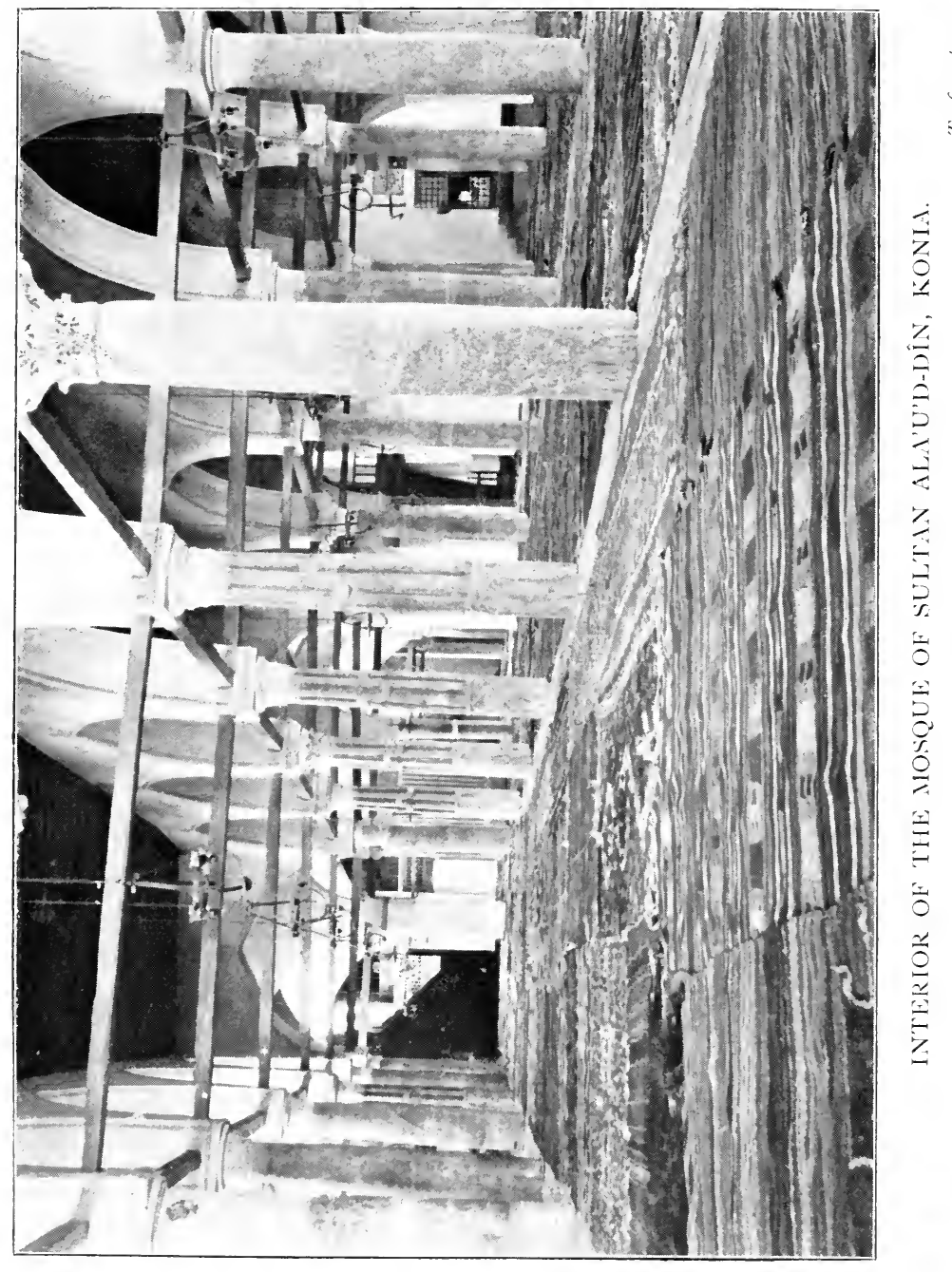


4 का

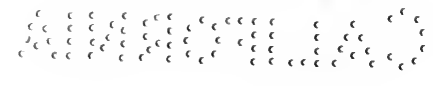


genius. Secondly, it contains the tomb of one of the holiest Sheikhs of Islam, the mystic Jelalu'd-Dîn er-Rûmi, author of the Mesnevi and of a celebrated Divan of poems, and founder of the Order of Mevlevis, or Dancing Dervishes. In Konia is the residence of his hereditary successors, who bear the title of Chelebi of Konia $;{ }^{1}$ in Konia is the mainspring of a great brotherhood which exercises a beneficent influence in the Ottoman Empire, in the direction of tolerance and breadth of mind, by means of its thousands of lay brethren scattered through every walk of life.

The annals of Konia carry us back to the mists of antiquity: we read of Ikonion in the legend of Perseus and the Gorgons. Here, too, in historical times, halted the Ten Thousand; here Cicero, Pro-Consul of Cilicia, reviewed his troops; here Paul and Barnabas preached the Gospel after their departure from Cyprus. And here, if we are to credit venerable tradition and oriental geographers, is the tomb of "Plato the Divine," who is invested in the locality, under

1 The Chelebi is officially addressed as "The Exalted Presence of His Eminence the righteous Veled Chelebi Effendi, who sits on the sheepskin (i.e., holds the office) of the Convent of the Holy Mevlana in Konia." 
the name of Eflat, with theattributes of a miracleworker and a magician. ${ }^{1}$ But it was not until it fell into the hands of the Seljuq Turks, branch of a race usually considered to be destructive in its tendencies, that Konia attained its zenith; it was not until after their disappearance that it lapsed into provincial obscurity which, but for the Mevlevi Dervishes, would have been yet deeper. Undoubtedly the presence of the Chelebis, and, latterly, the advent of the Baghdad Railway, have preserved Konia from the oblivion in which lie places like Kharput and Sivas. It is now quite a flourishing town of about 55,000 souls, and in it, or at any rate within the vilayet, as the $\mathrm{Vali}$ related to me with pride, were made all the fittings and furniture for the Chamber of the recently created Provincial Council. It offers, moreover, an example of what is almost a phenomenon in Turkey : it is a town the majority of whose inhabitants are Turks. The vilayet of Konia is, in fact, the only province of the Empire, with the possible exception of Brusa, the mass of whose population is Turkish. Nor are its people as the

1 Cf. F. W. Hasluck, "Plato in the Folk-lore of the Konia Plain," in the Annual of the British School of Athens, No. XVIII. 
Europeanized Turks whom one encounters in Constantinople; they are genuine Turks de la vieille roche, the core' and backbone of the Turkish race, people who dress as did their forefathers in the plateaux of Central Asia. The old men wear the gown, and round their fez a white or yellow turban; the younger generation affects the pretty distinctive dress of Konia, which consists of wide but not very baggy breeches, a zouave jacket of blue or dark olivegreen, a broad silk qushaq (sash), and an exceptionally tall fez, the end of whose püskiul (tassel) is tied within a black turban. People in fez and European clothes are almost invariably Armenian or Greek rayahs.

The houses of the native Christians and of the few European residents of Konia lie between the railway station and the old town; to the north of these rises the artificial mound on which were built the palace and mosque of Sultan Ala'u'd-Dîn. Ala'u'd-Dîn Kai Kobad I. was the greatest of his dynasty and a mighty builder, a veritable Seljuq Justinian; the memory of his name yet lingers in the lands over which he ruled. At the foot of the mound, above the decayed mud hovels of ancient 
suburbs, and amid countless turbehs of Peyghambers, Sheikhs and Pirs, are scattered his superb medresés (seminaries) and mosques, sadly dilapidated ruins of buildings which made Konia in the thirteenth century a seat of Islamic learning, and render it to-day a treasure-house of oriental art. Pre-eminent among them stands the Karatai medrese, with a matchless marble portico, and domed chambers of brick lined with crumbling tiles of blue. Near by is the medrese of the Inje Minaré, so called from a thin graceful minaret whose upper stages have unfortunately been destroyed by an earthquake. ${ }^{1}$ A little further away is the beautiful but ruinous Sirchali medresé (i.e., the "Glazed College," in allusion to its tiles), close to the Laranda Gate, which represents all that is left of Ala'u'd-Din's once formidable town walls. Outside the Gate is the Mosque of Sahib 'Ata, with two sumptuous porches; it contains a turbeh of the pious founder and his family, embellished with the best preserved tiles in Konia.

Of the palace of the Sultans of Rum on the mound there only remains a tower of mud

1 For a drawing of this mosque, made before the partial destruction of its minaret, $c f$. Cl. Huart, Konia, Paris, 1897 . 
bricks, standing precariously below the Mosque of Ala'u'd-Dîn. The mosque, however, is in admirable preservation; and on its interesting outer wall is a series of contemporary inscriptions, the first of which runs as follows :

Hath commanded the completion of this blessed mosque the mighty Sultan, Glory of the world and of the Faith, the victorious, Kai Kobad, son of the martyr Sultan Kai Khosrau I., son of Kilij Arslan II., the Proof of the Prince of Believers.

The interior has lost the tiled frame of its qibleh, which has been removed to the Imperial Museum in Constantinople and replaced by a painted imitation; otherwise it has undergone but little alteration since the days of its builder. It is of the type of the Omayyad Mosque of Cordova, and forty-two columns with a great variety of capitals support its low flat roof. So spacious is the mosque that lately 2000 soldiers recruited in the district were quartered inside it for three months before being sent to Chatalja ; would to heaven that some other barracks had been selected! It is asserted, and I can vouch from experience for the fact that the assertion is not made without reason, that the potentate known as Sultan el-Baraghit, the King of the 
Fleas, holds his court in the town of Tiberias ; but he must have appointed an exceedingly capable lieutenant to the Mosque of Ala'u'd-Din. Even Cyprus, at the height of its flea season, can produce nothing to match the hordes which swarmed from the floor and carpets of the mosque over the persons of its unsuspecting visitors. A poor Armenian bishop who happened to be in the mosque at the same time as myself flapped his robes in wildest agitation ; I rushed in despair to the nearest Turkish bath.

The forbears of Ala'u'd-Dîn rest in eight tombs of faience in a turbeh, or mausoleum, adjoining the mosque. It is a charming little sanctuary, the quintessence of a bygone East, a refuge of peace enshrining the remains of makers of history now all but forgotten. And over it rises one of those pyramidical domes which are distinctive of Koniote architecture, its tapering octagon a landmark in all the country around.

A pyramid similar to that which covers the remains of the Sultans of Rûm surmounts the 


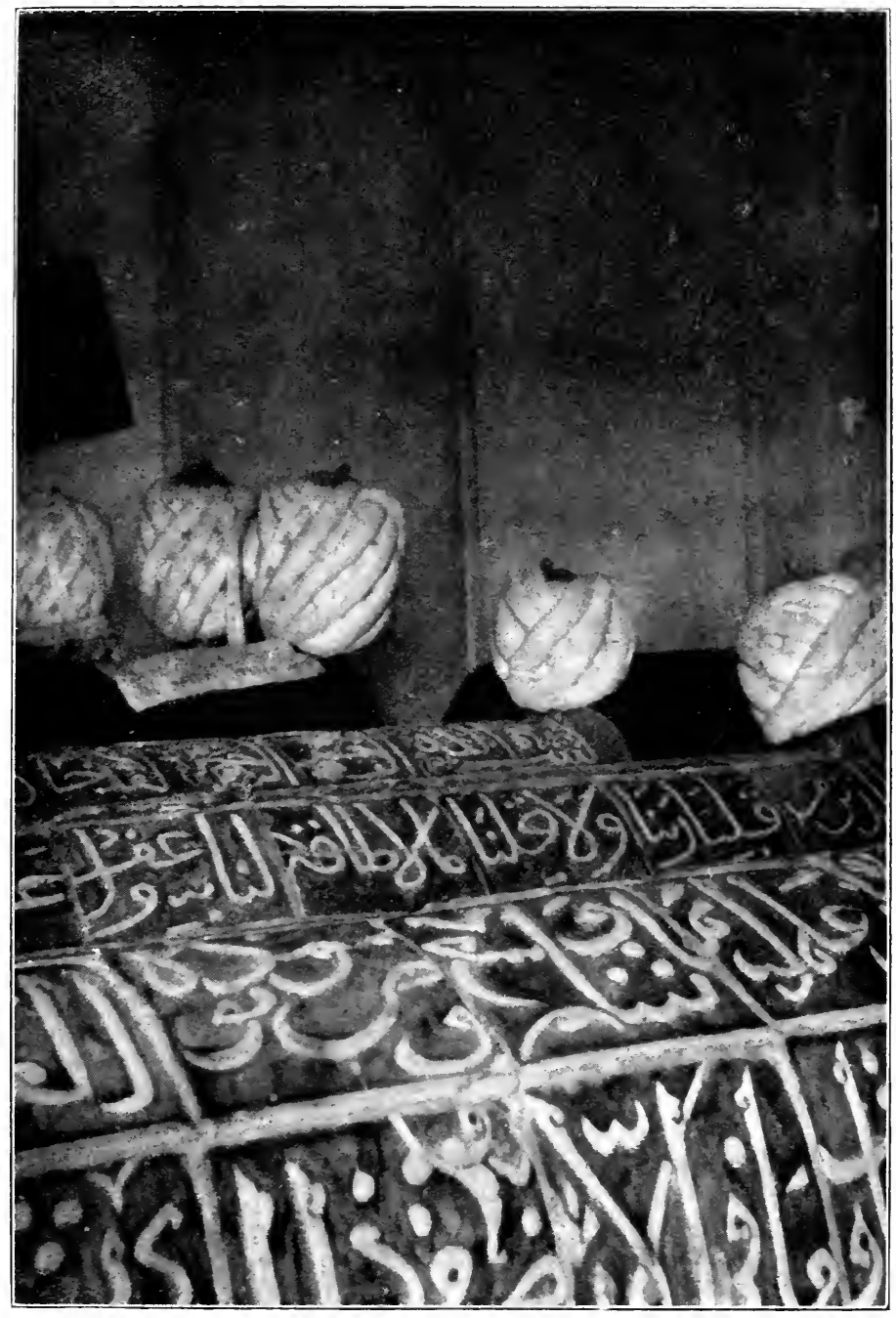

THE SLLT.AS OF RL'.I.

To face p. I6. 


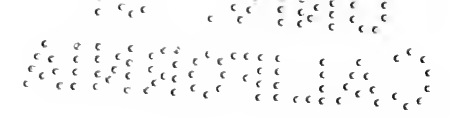


sumptuous tomb of Hazreti Mevlana, "Our Holy Lord," the Sheikh Jelalu'd-Din of blessed memory. With its facing of green faience, it is the most arresting object in Konia ; and draws general attention to the great Mevlevi-khané, the central convent of the dancing dervishes.

Jelalu'd-Dîn was a native of Balkh, in what is now Afghanistan, and with his father came to Konia early in the thirteenth century at the invitation of Sultan Ala'u'd-Dîn. Here he became acquainted with the Sheikh Shems ed-Din, a Persian Sufi, who dwelt in. Konia in the odour of sanctity, and from him is said to have imbibed the Pantheistic doctrines which he subsequently set forth with much poetic feeling in his celebrated work, the Mesnevi. The purpose of all Sufi teaching is to enable the devout soul to return to and be reunited with God, with Whom it was once one, but from Whom it has become separated by its birth into the world. The return journey to God is made along a "way" or "road" (tariq), whereby one of the dervish orders is to be understood; the stages of the "way" are represented by the $z i k r$, that is to say, the ritual (differing in every order) designed to produce the state of ecstasy 
wherein the mind is withdrawn from earthly things and brought into closer communion with the Divine. The zikr which Jelalu'd-Din instituted in his order to attain this end consists of whirling around to the music of flutes and drums ; the other characteristic of the Mevlevis (as, indeed, of dervishes in general) is the wide tolerance they display towards people and life in general.

A low entrance, protected by hanging chains, leads into the quadrangle of the Mevlevi-khané. On either side of the gate is a row of little cubicles inhabited by the resident dervishes, each cubicle surmounted by a picturesque leaden dome, the domes, again, separated by graceful hexagonal chimneys. In the middle of the court is a fountain, beside which a cluster of tombstones of deceased dervishes gleams in the sunlight; to the right are the refectory and common room of the living. The quadrangle is bounded at its further end by a large, richly ornamented building, or group of buildings, under whose many domes is contained every spiritual requisite of the order. Here is the tomb of Jelalu'd-Din, with those of his father and all his successors; next to these is a mosque 
for the performance of the ordinary namaz, and beside it the sema-khane, or dancing-room, where the zikr (called muqabile, "meeting") is performed.

I had brought letters of introduction to the Chelebi Effendi from the Vali of Konia, from the hereditary Sheikh of the Mevlevi tekye in Cyprus, as well as from other Turkish dignitaries, and was ushered by a swarthy dervish from Angora into his Eminence's apartments. These are situated at the right of the entrance gate, and do not differ in size from the cells of the ordinary brethren. They are so low that an exceptionally tall man would be obliged to stoop inside them ; on entering them one seemed to be transported into a scene from mediæval Persia as depicted in some illuminated manuscript of Behzâd of Herat. First I passed into a tiny yellow ante-room, whose most prominent object was a stove of Persian faience; this room gave access to an inner chamber filled with broad divans. The divans, which were raised barely a foot from the floor, were covered, like the floor, with costly stuffs; and on one of them, on a sheepskin rug, there reclined one of the holiest personages of the Moslem world, 
the holder of a dignity which commands profound veneration far beyond the confines of the brotherhood immediately subject to it. On another divan, opposite the Chelebi, squatted his Vekil, or second in command, writing, on his hand, a letter at the Chelebi's dictation. On one of the walls hung a representation of the high Mevlevi cap of camel hair, on the others a number of yaftés (illuminated texts), admirable specimens of oriental caligraphy; in a corner was heaped a mass of leather-bound tomes.

The blood of the mystic and philosopherpoet of Balkh would appear to flow with scarcely diminished purity in the veins of his successor and descendant of the present day. The thirtyninth or fortieth Chelebi of Konia (his Eminence could not remember precisely which) looks as much part of an old Persian miniature as do his surroundings. He is a man of about fifty, grave and amiable, with dark beard and features of high-bred Persian cast; the dignity of his presence was enhanced by his costume, a violet gown worn over a dark-green cassock. On his head he wore the cap of the order, encircled by a green turban. The green turban is the attribute of the Mevlevi Sheikhs, and if, as was 


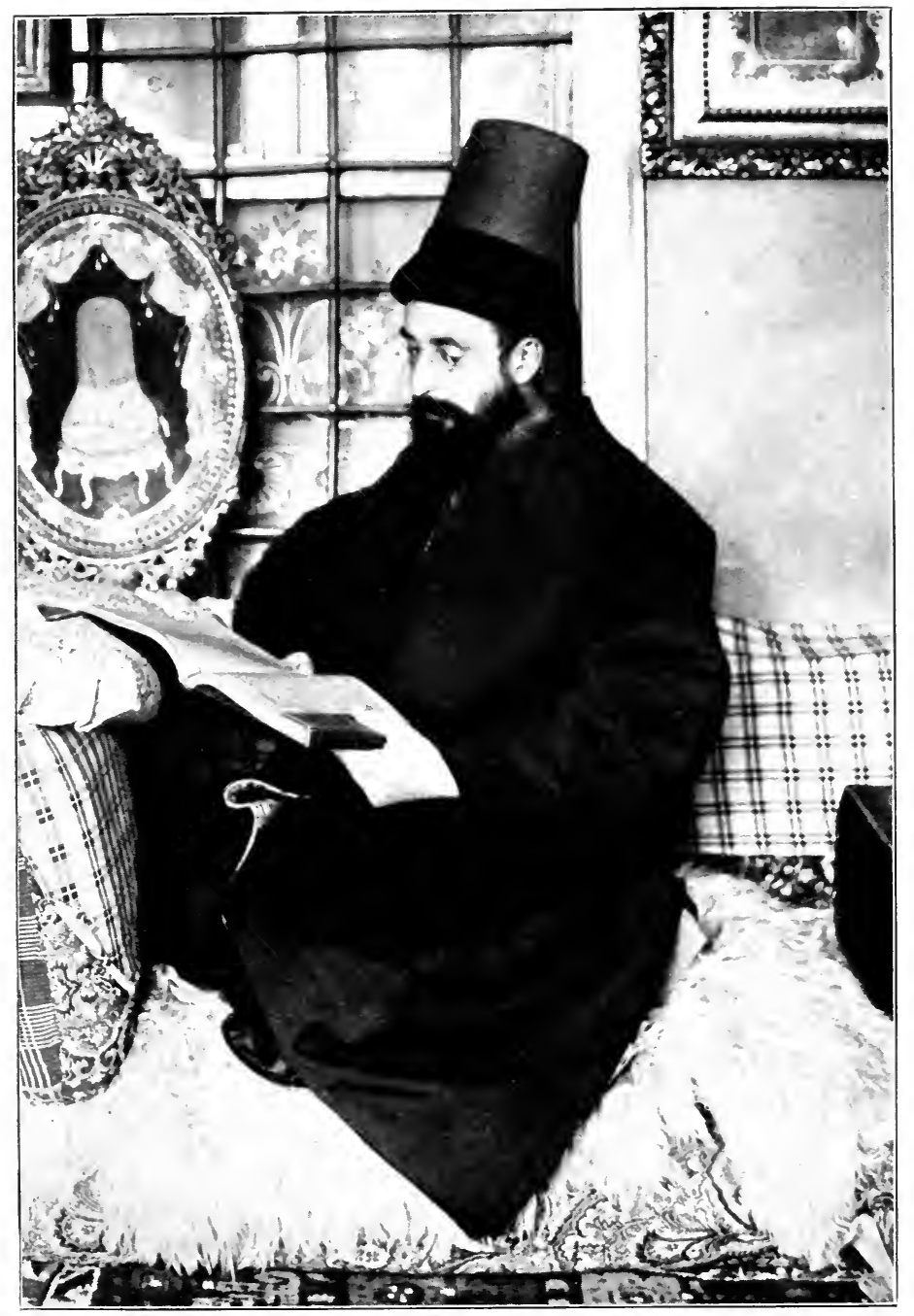

THE CHELEBI OF KONIA. 
(4) 
the Chelebi's, its lower side is tucked within the cap, it is a sign that the wearer is a descendant of Hazreti Mevlana himself.

His Eminence is a distinguished scholar and man of letters, well versed in the two languages, Arabic and Persian, from which literary Turkish has so copiously borrowed. It is a remarkable fact that while the spoken Turkish of the people contains relatively few foreign words, and is concise and laconic to the verge of ambiguity, the literary language becomes ambiguous for precisely the opposite reason. It teems with repetitions, with laboured circumlocutions, with endless gerundival clauses; it revels in elaborate Persian and Arabic phrases completely unintelligible to a Turk of but moderate erudition. The very word Chelebi, which has had a chequered and interesting history, is of Arabic origin. A Turkish corruption of the Arabic salib, a crucifix, it was applied, centuries ago, by the Turkish tribes of Central Asia to the only Christians with whom they were wont to come in contact, to the Nestorian priests who, during the Middle Ages, showed such astonishing missionary activity by carrying their faith into India, 
Siberia, and even into China. ${ }^{1}$ And as these Nestorians were usually men of learning the appellation was gradually extended by the Turks to any cultured Christians, and from them to cultured people in general. At the present time it is given, as a rule, to European gentlemen of a certain standing, and has even been applied to the writer by an over-polite Turk. It is, therefore, a strange anomaly that a designation eminently Christian in etymology and application should be the title of one who, next to the Khalif, may be regarded as the nearest approach to a sort of Suni Pope.

To continue the metaphor of the Chelebi as a Suni Pope-it is, of course, only true in the vaguest sense-it should be explained that it is his function to gird each Sultan of Turkey on his accession with the historic sword of 'Osman. This ceremony is performed in the sacred Mosque of Eyub, in Constantinople, to which no Christian is admitted ; and, in view of its reputed origin, cannot fail to suggest the analogy of the coronation by the Pope of the

1 This is the derivation which was given to me by the Chelebi Effendi. Many Orientalists prefer the derivation from chalab, an obsolete Turkish word meaning "God." $C f$. the Encyclopadia of Islam, vol. i., pp. 831-33. 
Holy Roman Emperor. It is said to have originated in the presentation by Ala'u'd-Dîn to the Turkish conqueror 'Osman of a sword, which he despatched, possibly in token of investiture, by his friend Jelalu'd-Dîn. The story is evidently inaccurate as regards detail, since the three personages can hardly have been contemporaries; but there is no reason why it should not be true in substance. It would be a very natural thing for one of the Seljuq Sultans, then the most powerful of Turkish Sovereigns, to congratulate the leader of a kindred tribe upon his victories over the Greeks, and to send him a sword of honour by the most distinguished man at his Court.

\section{IV}

Sir Charles Eliot remarks in Turkey in Europe that Jelalu'd-Dîn "was passionately devoted to music, and, like Luther, did not see why the devil should have all the good tunes." Jelalu'd-Dîn recognized in music man's ally in his search for reunion with the Infinite; in a passage of rare charm the Mesnevi suggests to the soul sorrowful how it may hope to attain its goal with the kindly help of the flute: 
Hearken to the pipe of reed, to what she recounts, to the sound of her plaint at the loneliness of the soul.

"Since the day I was cut," she says, "from among the reeds of the marshes, men and women weep at the sound of my voice. My breast swells as I strive to give utterance to my sighs, and to express the pangs of my yearning for my home. For all they who are far from home ever long for the day of return to whence they came.

"On behalf of the multitude do I pour forth my song; I am the companion of the happy and the sad. My notes are interpreted in accordance with the dictates of men's hearts, yet it is not given to all men to discover the secrets of my heart. My secrets are manifest in my plaintive song, but are not revealed to the earthly ear. Body is not veiled from soul, neither soul from body, yet what man hath set eyes upon a soul?"

This voice of the flute, it is of fire and not of wind ; may he who has not the fire be accounted as one that is not. For as the ferment of love possesses the wine, so does the fire of love give inspiration to the flute. The flute is the confidant of unhappy lovers $;^{1}$ in its strains are laid bare the secrets of my heart.

And so, twice a month, after Friday Mosque,

1 The words "love" and "lover" are used here, as in the Song of Solomon, in an allegorical sense. The lover is the creature longing for reunion with the Creator. 
do the Mevlevis of Konia whirl into ecstasy to the voice of the flute of reed. In Constantinople and other great cities frequented by tourists the ceremony is apt at times to degenerate into a spectacle provided for the curious; in smaller places, although its solemnity as an act of devotion is convincing and impressive, the resources of the tekye rarely permit of much outward apparatus. In Konia are combined the merits of great and small places. The sema-khané in the shadow of the Founder's tomb provides as dignified a mise-enscène as any ritual can require; in no distant townlet could the solemnity of the proceedings be surpassed. During the hour or so that the $z i k r$ is in progress the spectators stand with hands folded over their stomachs, the conventional attitude of reverence ; I noticed that some were moved to tears by its mystical appeal.

One by one the dervishes filed into the room, about thirty in all, men of all ages and from every part of the Suni world. Presently the Chelebi, with the other members of the hierarchy of the order, entered from the side of the tomb, and sat just beyond the dancing-floor, while a precentor chanted in doleful Dorian 
mode portions of the Mesnevi in the original Persian. After some prayers they passed in procession into the sema-khané, followed by the dervishes in order of seniority; as each passed the point behind which was the Founder's tomb he turned and bowed to the man who followed. Three times the dervishes processed around the room. Then, as the Chelebi went to his allotted place, the dervishes who composed the band repaired to a raised platform, where their flutes and drums were in readiness, while the others threw off the cloaks which covered their dancing dress of long, pleated skirt and zouave jacket, green or white. The flutes broke into a melancholy wailing tune, and the dancers proceeded to revolve, their skirts opening with the motion like those of a ballerina. For twenty minutes or so they continued, while one of the senior dervishes, whose function was evidently to supervise, walked about among the dancers like a sort of drill sergeant, seeing that all was well. Then a pause; then a fresh tune, rather like a catchy Italian waltz. Another pause; and the musicians struck up music more weirdly melancholy than that which they had played at first. This was the tune set apart for the rare 


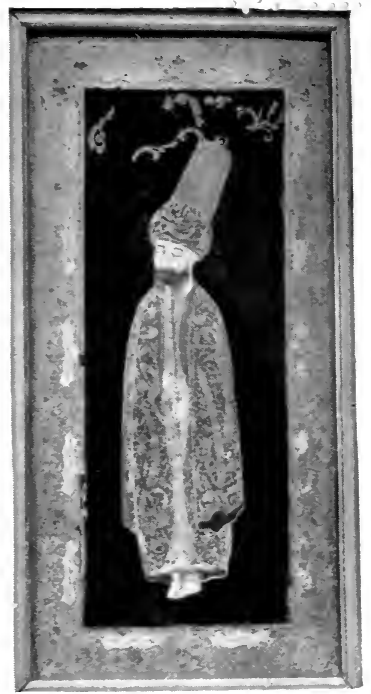

A MEVLEVI ADEPT PLAYING THE FLUTE.

From an old Turkish miniature.

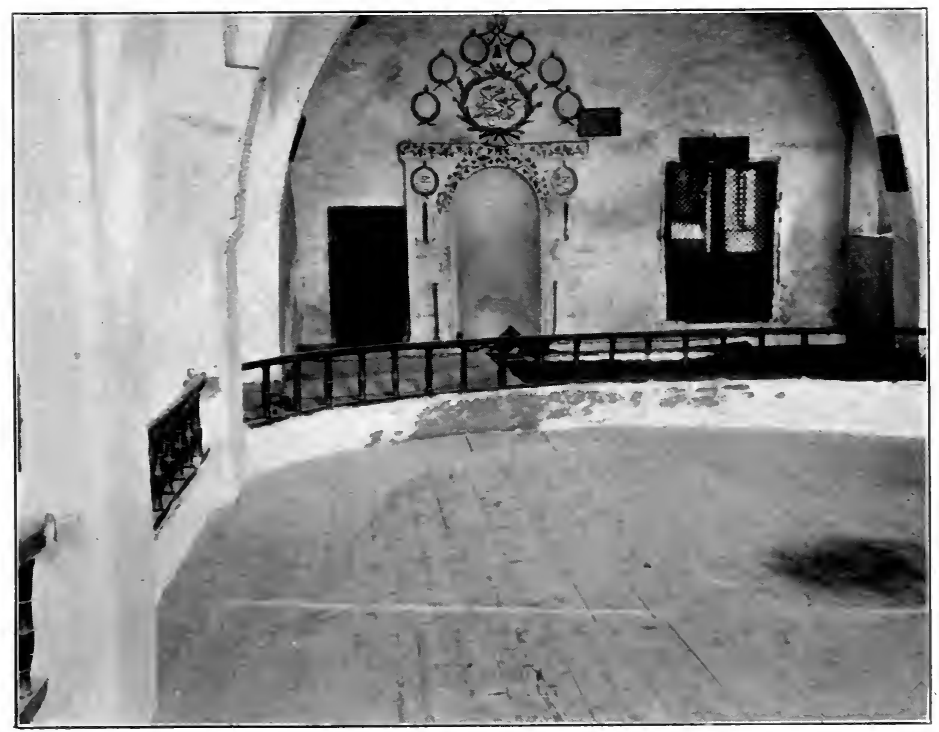

THE DANCING-FLOOR OF A SMALL TEKYÉ.

To face p. 26 . 
○.॰ 
occasions when the Chelebi himself deigns to dance; and a noticeable thrill went through the assembly as the Chelebi moved slowly into the middle of the floor, and with a dignity which few Occidentals could emulate, none, certainly, under the same circumstances, became the pivot around which the others gyrated. After the ceremony I overheard a man, evidently a wellto-do countryman, say to his neighbour: "Do you know what I was thinking when the Chelebi Effendi began to dance? I thought he was going to fly."

At the end of the service the precentor intoned a lengthy bidding prayer, to commemorate the Founder and his successors, and closed with supplications for the present ruler of Turkey, "Es-Sultan, Es-Sultan, Es-Sultan, Mehmed Reshad Khan." Upon these he dwelt with particular emphasis, for Sultan Reshad, probably the most devout sovereign who has sat on the throne of 'Osman, is himself a Mevlevi, the most distinguished lay-brother of the order. During the long period for which he was confined to his palace by 'Abdu'l Hamid he steeped himself in the precepts and philosophy of Jelalu'd-Dîn er-Rûmi. So I was told by the 
Chelebi himself, who knows his Majesty well. The Chelebi had lived in Constantinople for twenty-five years before succeeding his cousin, the late Chelebi, and was full of praise for the piety of his Imperial fellow-dervish.

Before the Chelebi and his officers retired from the building they spent some minutes in prayer at the tombs of Jelalu'd-Din and his successors. That of the Founder is covered with a magnificent pall of green satin, heavily embroidered with gold, and lies in a chamber or chapel decorated with sumptuous but subdued magnificence. Thick columns, covered with gesso and coloured deep red and gold, support the dome; the walls are similarly decorated. Silver steps, kissed by the faithful, lead to the solid silver balustrade which encloses the chapel ; above it hang heavy silver lamps. To the left is the imposing tomb of Jelalu'd-Din's father, Beha'u'd-Dîn, who is buried erect, as he died. The story relates that, as he lay on his deathbed, Mohammed descended from heaven to visit him; Beha'u'd-Dîn raised himself with a supreme effort to receive his august visitor, and, so doing, expired. The other tombs lie beneath stalactite vaults and are almost equally rich. 
Many are covered with priceless Kashmir shawls of the finest workmanship, others with satin palls; all are surmounted by the dervish caps of their occupants. The combined effect of this necropolis of the oldest dynasty in Turkey is one of restrained and impressive splendour.

On either side of the entrance gate, each in their separate apartments, the Chelebi and his Vekil were now holding a sort of levée. Shoeless and in deferential attitude there sat with the Chelebi two Government officials, a Sheikh of the Bektash Dervishes just arrived from Constantinople, and a wealthy landowner of Daghestan who had come to Konia from his distant home to see something of the West! After I had joined them and had consumed my cup of coffee, his Eminence invited me to lunch with him on the following day at his country residence in Meram, the summer resort to whose copious springs Konia probably owes its foundation. So on the morrow I drove along six miles of shady avenue to a large, simple Turkish country house, set amid leafy arbours, green meadows, wide kitchen gardens, and the sound of running waters. The atmosphere of the place was 
totally different from the Persian mediævalism of the Konia convent. The ecclesiastical element was absent; one felt one was in the pleasaunce of a Turkish grand seigneur of the eighteenth century. This was no monkish dwelling, but the manor of some old Dere-beyi, ${ }^{1}$ one of those feudal landowners who once divided the soil of Turkey between them, but have disappeared from Asia and only survive (with abrogated political privileges) in the regions of Bosnia and Albania. On the soft turf, under the shade of poplar trees, a table was spread, and for nearly two hours a dervish attendant brought and removed a bewildering number. of viands, all contained in metal dishes, from which one helped oneself directly with one's fork. The order of the courses was something as follows, meats, vegetables, and sweet dishes being interspersed with delightful inconsequence:

Grilled pieces of mutton (kebab).

Meat patties (bürek).

A sweet pastry with honey (baqlawa).

Stuffed aubergines.

Vegetable marrows stuffed with rice.

1 Lit., "Lord of the Valley." 


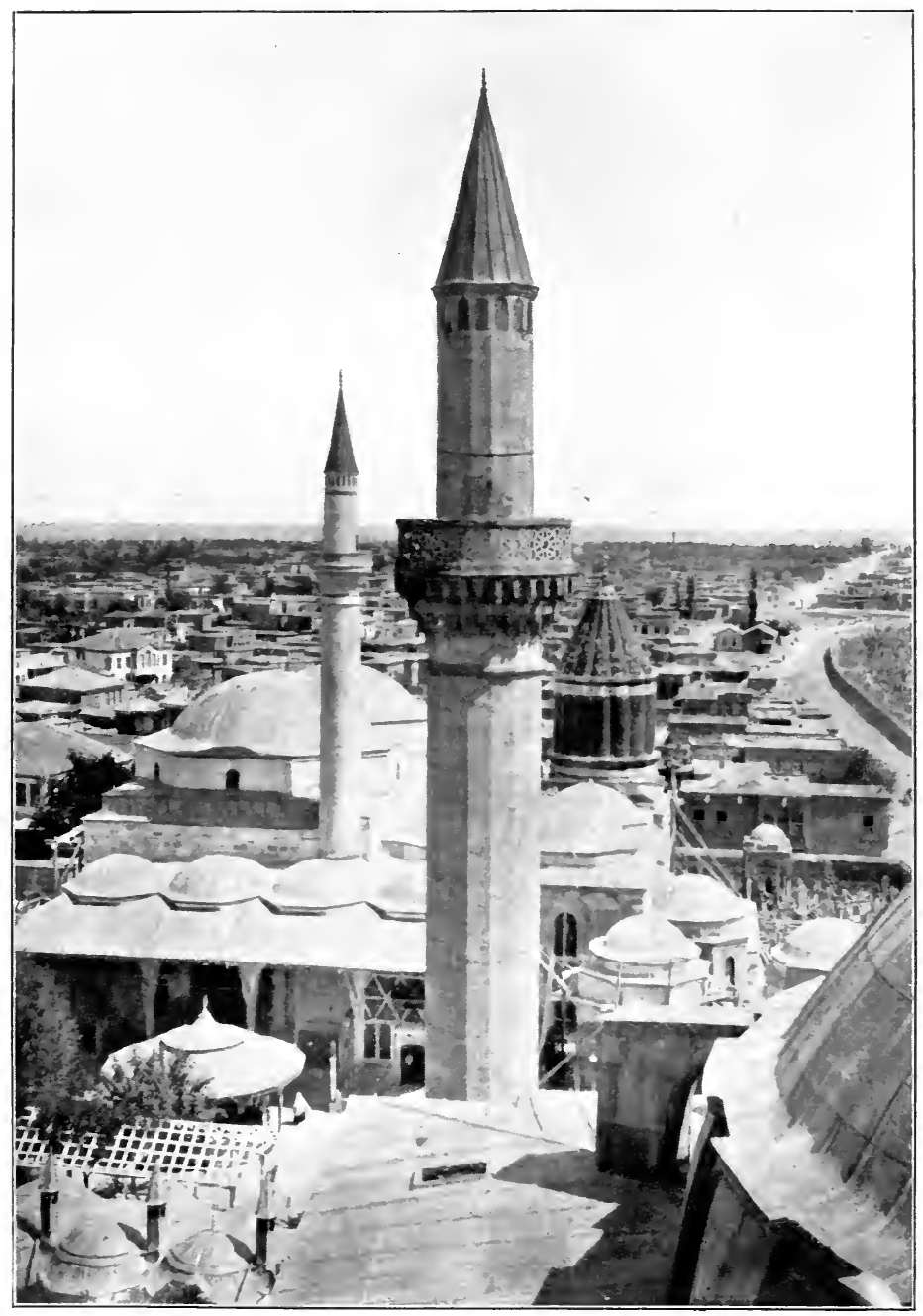

THE MEVLEX'I-KHANÉ.

From a Minaret of the Selimiyeh Mosque. 


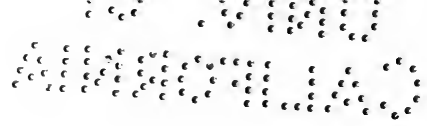


Stuffed tomatoes.

A sweet rice pudding with cream.

Stewed okras.

A sauté of mutton and vegetables.

Pilaw.

Pears stewed in their skins.

Melons.

In addition there were side dishes of cheese, salad, and pimentos. A certain historical interest attaches to the pilaw, which was sweetish and flavoured with the curious combination of beans and currants. The dish is traditional among the Mevlevis, having been made in precisely the same proportions and cooked for precisely the same number of minutes daily for six centuries. It is the pilaw which was always prepared for Hazreti Mevlana by his faithful cook, whose turbeh is still to be seen in a grove of reeds by one of the streams of Meram.

And since I have reverted to the reed, to the emblem of the Mevlevi Dervishes, I would conclude with the mystical account of its sacred origin as preserved in the traditions of the Order.

The Prophet Mohammed once entrusted to 
his son-in-law 'Alî certain holy mysteries of the faith, enjoining upon him to reveal them to none but the initiated. For the space of forty days 'Alî locked the secrets within his heart, but in doing so he was much troubled, so that he fell ill, and began to swell. He fled, therefore, into the wilderness, where he chanced to come upon a well. Unable any longer to contain the holy mysteries, he leaned over the mouth of the well, and confided them to the bowels of the earth. With the excitement of pronouncing the portentous words his mouth filled with froth and foam, which he spat into the well; and immediately he felt relief.

After a number of days a single reed shot up from the well. A shepherd boy, miraculously enlightened by God, saw the reed and cut it. He drilled seven holes in its side, and upon it, as he pastured his flock, he played the sweet melodies which afterwards were played by the Lord Jelalu'd-Din. Presently the wind carried the sounds of his music abroad, and the tribes of the desert, hearing them faintly from afar, came near that they might listen, bringing their flocks with them. And whenever the shepherd boy played, even the camels and the sheep 
ceased from pasturing, entranced with the sweet notes of the flute.

And when word was brought to the Prophet Mohammed of the musician who had arisen in the desert, he declared that in the notes of the flute lay the interpretation of the divine secrets confided to Hazreti 'Alî, and that thereafter the flute should be the companion and comforter of man. 

II

THE KHOJA OF AQSHEHIR 

THE KHOJA OF AQSHEHIR

I

THE works of Turkish authors are not, in general, appropriate for those in search of light reading. To compose a book in their ornate and cumbrous style must be rather like grappling with a prolonged series of jig-saw puzzles; the perusal of such a volume may be likened to a surgical operation, and is, consequently, not often undertaken. The only book which the average Turk has constantly at his hand is the Qoran, into which even the shopkeeper dips in the intervals of selling his wares; but as the Qoran is written in Arabic, and in archaic Arabic to boot, he reads it as a pious exercise, and not in the expectation of being able to understand it. There exists, however, in Turkey another class of literature, which differs from the ponderous 
works of poets and historians as Klephtic ballads differ from the turgid efforts of modern Greek prose writers. This class supplies the literary wants of the masses, and is more widely circulated by recitation than by the printing press. It consists of the dialogues associated with the names of Karagyöz and Haji Aivat, of folk tales and fables, of songs and jokes; its most characteristic product is the classical exponent of Turkish humour, the Khoja ${ }^{1}$ Nasr ed-Dîn.

The Khoja was an Imâm, a sort of country parson, who lived some 500 years ago at Aqshehir, in Asia Minor; yet it is not to sanctity or learning that his celebrity is due. Of these attributes he had but little store. His character was a curious blend of cunning and naïveté, of buffoonery and shrewdness; his main occupation in life to score off other people and to play harmless practical jokes. In pursuit of this object he became the author or hero of countless adventures and jeux d'esprit, which are related in houses and coffee-shops wherever Turkish is spoken, as well as the peg on which

1 The word Khoja, more properly transliterated Khwaja, but pronounced in Turkish as it is spelled here, means a schoolmaster, a teacher, especially of the 'ulema class; a teacher of divinity. 
similar tales of later invention are hung. Some of the Khoja's adventures are really funny, some depend for their humour on Turkish puns, and thus lose their point when translated, some are too Rabelaisian to bear publication. But as the jokes of five centuries have been fathered on to the Khoja, he must not be held responsible for all that bear his name.

Aqshehir lies about I 10 miles from Konia, in the direction of Afiun Karahissar ; and I made a pilgrimage to the pretty and eminently Turkish little town to see the Khoja's grave, and to glean, if possible, at its source some fresh emanation of his genius. "The White Town" is situated very picturesquely at the foot of the Sultan Dagh, at the very spot where a deep cleft or valley cuts into the mountain. A river flows down the valley, and, on entering the town, separates into many streams, which run along the streets. Such part of the river as is not carried off in this manner finds its way into a stony bed, and becomes one of the boundaries of the graveyard just below the town. Here rests our friend the Khoja, in a conspicuous and recently restored mausoleum of marble, gleaming against a background of mosques and 


\section{0

minarets and the brown and green tints of the Sultan Dagh. It is believed by many people that a gate without any walls gives access to the tomb, a belief which, although erroneous, is justified by other of the Khoja's whimsicalities. At his request a small hole has been left in the masonry of the tomb, so that he can continue to look out upon the world; over the grave, ready for instant use, hang the ball with which he played, and the lock of his house; which he refused to entrust to his wife, who lies beside him. The inscription is as follows :

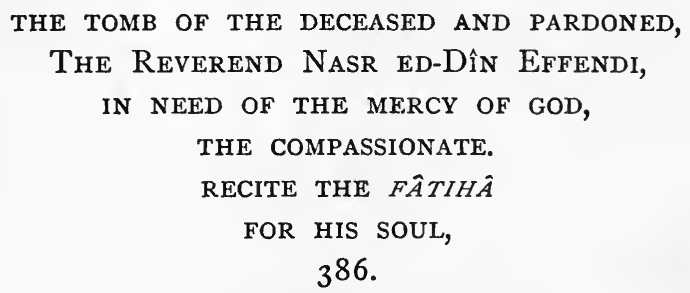

Even here he played a joke upon the world, for A.H. 386 is equivalent to about A.D. 996, whereas the old reprobate was, as we know, a contemporary of "Lame-I ron," Timur-lenk, who died in I405. The Tatar invader made a sort of Court jester of the Khoja, and figures in many of his stories, as the following examples will show : 


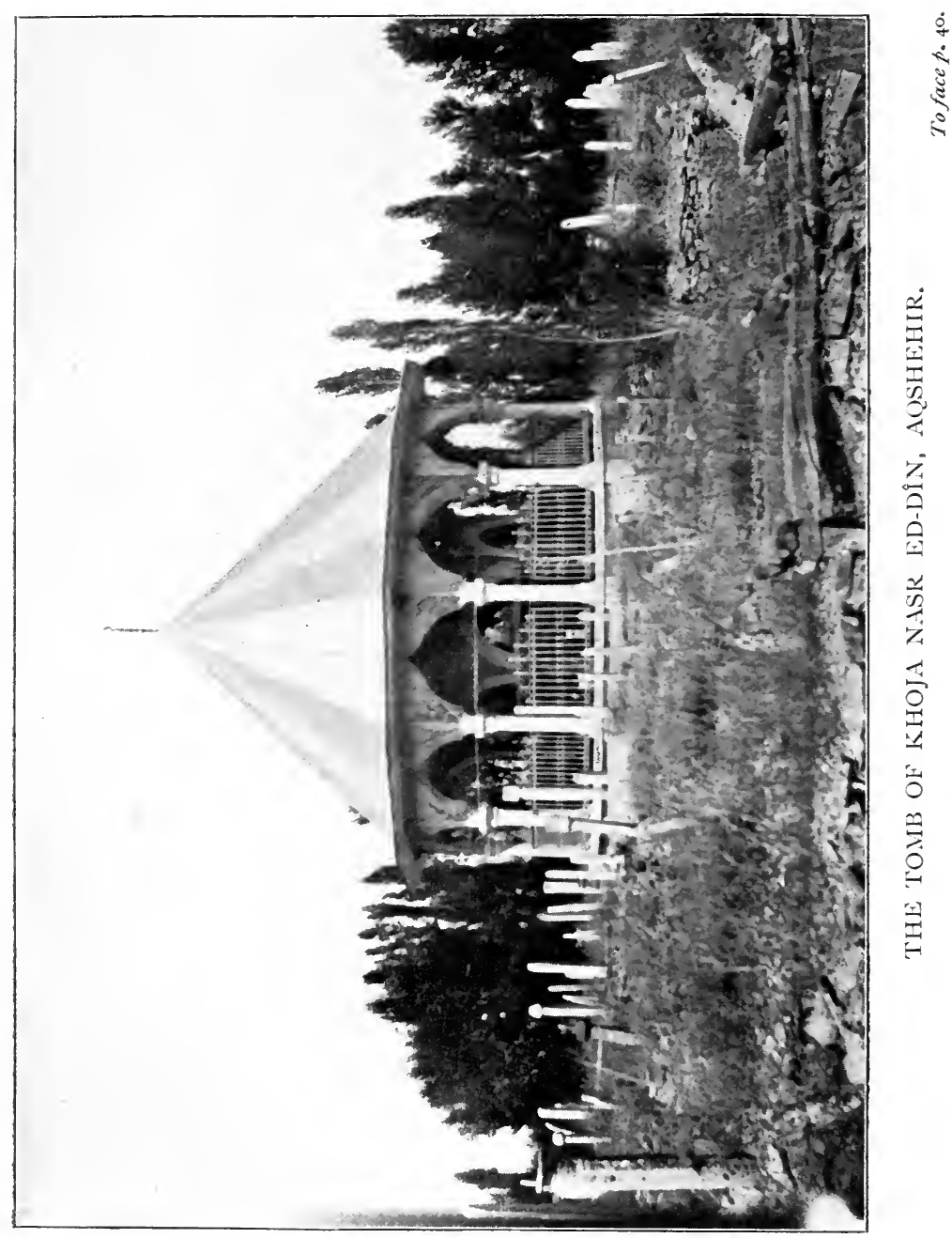


(4) 
Timur-lenk was not only lame; he had also lost an eye, and was very ugly into the bargain. One day, as he sat conversing with the Khoja and his courtiers, he chanced to scratch his head, whereupon, noticing that his hair was rather long, he called for the barber. The barber shaved his head, and, when he had finished, handed him a mirror. Timur studied his features attentively for a while, and then, dismayed by his ugliness, began to weep. At once all present proceeded to weep in sympathy with their master. Presently, by means of jokes and stories, the courtiers succeeded in rousing Timur from his grief; but the Khoja wept all the more loudly.

Timur looked at him in astonishment, and asked him the cause of his sorrow. "I wept with reason," he said, "at beholding my ugliness, I the Lord of so many lands, the master of countless slaves. But I do not understand why you should thus despair."

"If you, my Lord," replied the Khoja, "wept for two hours after seeing yourself in the mirror for but an instant, is it not natural that I, who see you all day long, should weep longer than you ?" 
On hearing this answer, Timur burst into uncontrollable laughter, and the Khoja, in order to render himself still further agreeable, proceeded to a neighbouring village celebrated for the quality of its geese and cooked a goose as a present for him. But on his way back he became hungry, pulled off one of the goose's legs, and ate it. When he presented the bird, Timur, indignant at the Khoja's effrontery, asked what had become of the missing leg.

"In our country," said the Khoja, "geese have only one leg. If you don't believe me, look at that flock of geese over there, by the pond."

And he pointed at a number of geese, who, as it happened, were all standing on one leg. At once Timur ordered a drum to be beaten, and the noise so startled the birds that they instantly put down the other leg.

"You see," said Timur to the Khoja, "that they are now standing on two legs."

"Yes, and I daresay," replied he, "that, if the drum were beaten loud enough, you could be made to stand on all fours."

In his lifetime the Khoja affected an enormous cap stuffed with cotton, of an obsolete shape 
which resembles a melon and is called by the Turks qavuq; in death this covering still lies above his head. Now, however, it is more gigantic than ever, because pious visitors are in the habit of adding successive layers of cloth as those below wear out. The Khoja enjoys, as is natural, great vogue in Aqshehir. While I was at the tomb, three lads, who had just been called to the colours, came up to invoke the Khoja's blessing and to register wishes, which are believed to come true. On Fridays and festivals the grave is decked with a handsome satin pall, the gift of an Aqshehir company in some regiment. Moreover, at the two Bairams all the Moslems of the town repair to the mausoleum; and on these occasions its custodian receives the small donations of which his stipend consists. His office is hereditary in the Khoja's family, and has been so from the time when "the memory of man runneth not to the contrary" ; but early in the nineteenth century, on the death of one of his predecessors, the succession was in danger of being broken. It was suddenly discovered that the firman by which the post was held was missing, and several claimants came forward in addition to 


\section{THE KHOJA OF AQSHEHIR II}

the present holder's grandfather, who was the person properly entitled to it. Unfortunately the rightful heir lacked the document whereby to prove his claim, so the only thing for him to do was to go to Constantinople and make a personal appeal to the Sultan. Accordingly, he set out on his pony, and eventually arrived one evening at the Seraglio Gate in Stambûl. The story that follows is well known, but, as I had it from its hero's grandson at the foot of Khoja's grave, its repetition here will perhaps be forgiven. On arrival, our friend proceeded to tie up his pony, and then sought lodging in a khân. But in the dark he had tied the beast, by mistake, to one of the large drums used by the Janissaries; and soon it discovered that it was attached to something movable, and began to kick about. It naturally made a fearful din, and, as this happened at the very time that Sultan Mahmud II. was contemplating the extermination of the Janissaries (actually carried out in 1826), the utmost excitement ensued. The Sultan thought the Janissaries were rising, the Janissaries thought the Sultan had given orders for their massacre; and it was not for some time that the innocent cause 
of the commotion was discovered. No further evidence was required as to his descent from the Khoja; the firman was granted at once.

Equally convincing is the claim of the present custodian, his grandson. The artist who illustrated the Turkish edition of the Khoja's adventures has undoubtedly taken as the model for his hero the droll little person who now tends his illustrious forbear's shrine, clad after the whimsical fashion of the genial Nasr edDîn. In his tiny hut beside the tomb I sat and drank coffee, as with twinkling eye and the gifts of a born raconteur this chip of the old block related "Khoja stories" for many hours without tiring, stories which follow, interspersed with others that I have gleaned at various times in the course of previous wanderings in the Levant. The hut consisted of one small room, and its only contents were a board which did service as a bed, the much worn and perforated fragment of an ancient rug, and, running around the walls, a raf, or shelf, on which were ranged the old fellow's scanty store of pots and pans and cups. I asked him how the old rug had come into his possession, whereupon he told me the following story : 


\section{THE KHOJA OF AQSHEHIR II \\ "By some misfortune," he said, "Khoja}

Nasr ed-Din once fell into great poverty, and was obliged to ask his neighbours for a little corn wherewith to feed himself and his family. But the neighbours refused to help him, so Nasr ed-Dîn Effendi bethought himself how to repay them for their uncharitableness. Now it was the winnowing season, when the people of Aqshehir are dependent upon the wind from the valley of the Sultan Dagh behind us; and across this valley Khoja Nasr ed-Dîn proceeded to stretch the very rug which you see here. Then he prayed to God that $\mathrm{He}$ would suffer the rug to hold up the wind, and God granted his prayer. The wind ceased, and the people were unable to proceed with their winnowing.

"An old woman went up the valley to see what was the matter, and found Khoja Nasr ed-Dîn sitting beside his rug.

" What has happened to the wind, Khoja? she asked.

"I have stopped it with this rug to punish you folk for your greed,' replied he.

"The old woman, who feared much to lose her grain, begged earnestly that he would make an exception in her favour. 
“" ' I will give you two kilés ${ }^{1}$ of barley, Khoja Effendi,' she pleaded, 'for a blast no thicker than your finger.'

“' Very well,' replied he; 'go home, and the wind shall follow.'

"Thereupon he poked a finger through the rug, and instantly a small current of wind, one finger's worth, passed over her winnowing floor, and over hers alone.

"Soon the old woman's neighbours discovered that she was winnowing, and came in haste to ask how she had obtained the wind.

" ' I bought it from Khoja Nasr ed-Dîn up there,' she announced, 'for two kilés of barley.'

" 'Bosh,' ${ }^{2}$ they said; 'how can the Khoja sell wind?'

" 'Go and see for yourselves if you don't believe me,' she retorted; and in due course they all bought wind from Khoja Nasr ed-Dîn for many kilés of grain.

"From this store," concluded the old man, " Khoja Nasr ed-Dîn Effendi gave' generously

1 An Arabic and Turkish measure of capacity, having no connexion with any metrical system; a bushel.

2 The literal meaning of the Turkish word bosh is "empty." Hence its secondary meaning "nonsense," with which it has passed into English parlance. 
to the poor; and you will now understand why my rug is so full of holes."

I have remarked above that the Khoja's main occupation in life was to score off other people and to play practical jokes on all and sundry. He was no respecter of persons, and the great ones of the land, not excepting, as we have seen, the dreaded Timur-lenk himself, were the victims of his drolleries as much as his humbler friends and neighbours and his long-suffering and all too patient wife. But the Khoja's peculiar charm lies in the fact that he is as foolish as he is wise, that in all his doings buffoonery alternates with shrewdness, simplicity with guile; that the laugh is as often against him as against his victims. $\mathrm{He}$ is at his best, perhaps, not in trying to score off others, but in defeating the aims of those who try to score off him; for it can well be believed that practices such as his tend to invite retaliation. It is not to be supposed that so popular a character as the Khoja has not been introduced ere now to Western audiences. He tempted the linguistic voracity of George Borrow to add Turkish to the thirty-four other languages from which that erratic genius had already made 


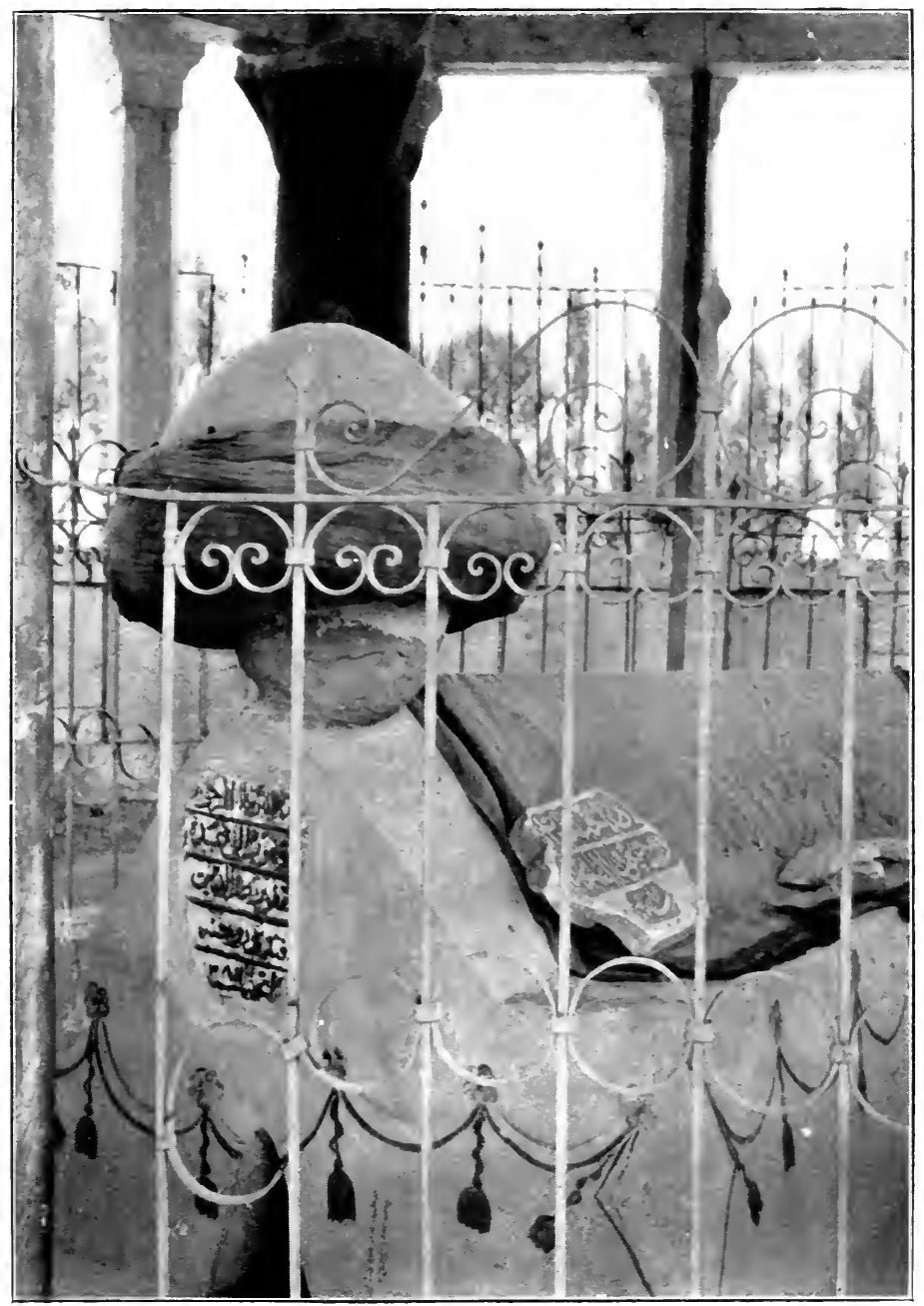

'THE KHOJA'S GRAVE.

Observe the Khoja's window below the inscription. To face p. 48 . 


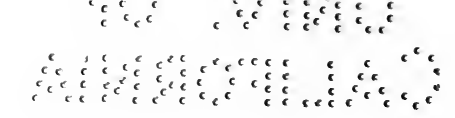


translations; samples of his adventures have been published in many countries of Europe. The titles of these collections will be found in the bibliography hereto appended; and, before embarking on a recital of the stories, I must express my acknowledgment of the assistance derived from some of the works quoted, which I have consulted for purposes of reference and comparison.

Although the late ${ }^{1}$ Khoja Nasr ed-Dîn was no mirror of learning, he had contrived to become the oracle of his fellow-townsmen, who were wont to consult him on every sort of subject. One day a camel passed along the street in which the Khoja lived, and one of the Khoja's neighbours, who had never seen a camel before, ran to ask him what this strange beast might be.

"Don't you know what that is?" said the Khoja, who also had never seen a camel, but

1 In the Turkish editions of the stories the Khoja is usually alluded to as Khoja merhum, "the late Khoja." The word merhum is only applied to Moslems, and literally means "received into God's mercy." Cf. the Greek $\mu a \kappa a \rho i \tau \eta s$ and the German selig. 
would not betray his ignorance; "that is a hare a thousand years old."

The man was much impressed with the Khoja's wisdom, and on the following day brought him a letter, which he asked him to read out to him. Now the Khoja could not read, but was ashamed to confess the fact, so he took the letter, and began with "'azizim Effendim, my sweet Sir," the salutation which a friend usually employs when writing to another.

The man interrupted the Khoja with a puzzled air to point out that the communication was a demand for the payment of a bill, not a letter from a friend.

"Why did you not tell me that before?" asked the Khoja, distinctly nettled; "if I had known, I would have read it quite differently."

Despite his intellectual preoccupations the Khoja condescended from time to time to help his wife with the housework, and in particular with the washing. But it invariably happened, much to his disgust, that on these occasions it began to rain. One day he went to buy soap in the bazaar before taking the linen to the 
washing-place, and said to the soap-seller, "Give me two okes ${ }^{1}$ of that cheese."

"That is soap, not cheese," replied the dealer.

"I know that perfectly well," retorted the Khoja, "but I call it cheese so that the rain shall not think I am going to do my washing."

After finishing his work the Khoja came home with the intention of eating some real cheese, to which he was much addicted, and was sorely distressed to find that a salted cheese which he had bought on the previous day had been stolen. As soon as he made the discovery he ran in haste to the well near his house, and sat down beside it.

Several hours later, a neighbour, passing by, asked him what he was doing there.

"Some one has stolen my salted cheese," said the Khoja; "and as everybody comes to the well after eating salted cheese, I shall be sure to catch the thief."

But the thief had evidently slaked his thirst elsewhere, and the Khoja's larder was empty; so he decided to plunder a neighbour's kitchen-

\footnotetext{
1 A Turkish measure of weight : 24 $\mathrm{lbs}$.
} 
garden. As he was stuffing turnips and cabbages and anything he could lay hands upon into a sack, the owner of the garden unexpectedly appeared, and asked the Khoja what he was doing.

The frightened Khoja could think of no better excuse than that he had been blown into the garden by a terrific wind.

"But who has pulled out all these vegetables ?" asked the owner.

"Surely," said the Khoja, "a wind which is strong enough to blow me here is strong enough to uproot your vegetables."

"But who put them into that sack?" persisted the owner of the garden, wondering what the Khoja would say next.

"That is just what I was trying to think," said the Khoja, "when you arrived."

The owner took the sack of vegetables and sent the Khoja away with a good beating, so that the hapless Nasr ed-Dîn trudged homeward without having replenished his larder. But, as he neared his house, he noticed a dead chicken lying in the road. Looking round stealthily to see if he was observed, he picked it up and concealed it in his kiürk (fur-lined gown), then 
took it home, plucked it and cooked it, and set it on the table.

But some one who had been watching him came in and said, "For shame, Khoja! That fowl is unclean; no man has killed it."

"Fool!" said the Khoja. " Do you maintain that this fowl is unclean because God has killed it and not man?"

That night, as the Khoja lay in bed, he dreamed that somebody was offering him a present of nine paras. He was not satisfied with the amount and said, "Give me ten."

Meanwhile he awoke, and found his hand empty.

Bitterly disappointed, he closed his eyes again, held out his hand, and said, "I have changed my mind. I will take the nine."

The Khoja once went into the mountains to collect firewood. Having gathered as much as he wanted, he loaded it on to his donkey, together with his cloak, and then said to the donkey, "You take that road and I will take this one. Let us see which of us will return home first."

The Khoja then hastened back and asked his wife if the donkey had arrived. His wife 
said that she had not seen the donkey since the Khoja had left the house with him, so the Khoja, after waiting a while, went back in search of him. He found the donkey browsing in the place where they had parted, with the firewood still on his back, but without the cloak, which some thief had evidently stolen.

In furious tones the Khoja demanded of the donkey what he had done with the cloak, but the donkey made no reply-for never yet has a beast spoken.

"Very well, then," said the Khoja, taking the saddle off the donkey; "when you give me back my cloak I will give you back your saddle."

And, carrying the heavy saddle himself, the Khoja led the donkey home. Just as he was putting him in the stable, a man knocked at the door of the house and asked if he might borrow the donkey. The Khoja replied that the donkey was away in the field, but at that moment the beast brayed and so betrayed, its presence.

"Ah, so the donkey is here after all ?" said the man.

"O, fool, begone! Would'st thou believe my donkey before me?". 
A few days later the donkey strayed and could not be found. The Khoja ran all over the town looking for him, at the same time exclaiming loudly, "Praise be to God!"

Some passers-by whom he had induced to help in the search asked him what his reason was for praising God thus loudly.

"I praise God," replied the Khoja, "because I was not on the donkey's back when he disappeared, for, if I had been, we should both infallibly have been lost."

And it is probable that the Khoja spoke the truth, to judge from his method in looking for a ring which he had lost. His wife, seeing him looking for something in the street, called out, "Khoja, what are you looking for?"

"I am trying to find my ring," he answered. "Where did you lose it?" asked his wife.

"In the house."

"Then why are you looking for it in the street?" his wife cried out in amazement.

"Because it is much too dark in the' house 'but light out here."

One Friday afternoon, as the Khoja and his wife were walking by the river bank, his wife fell in and was carried away by the current. 


\section{THE KHOJA OF AQSHEHIR}

Forthwith the Khoja began to run up-stream, crying out that his wife had fallen into the river.

"But what are you running up-stream for?" asked some passers-by; "the river must have carried your wife down-stream."

"Not at all," panted the Khoja; "you are mistaken. My wife has so contrary a nature that she would certainly insist on being carried up-stream."

Nevertheless, the poor woman came safely to land, but was seized in the night by a severe attack of ague. She awoke the Khoja and begged him to run for the doctor, but no sooner had the Khoja left the house than she called out to him from the window not to go, as the ague had left her.

The Khoja, however, went on and said to the doctor, "My wife was taken ill and sent me to fetch you. Now she is well again, so I have come to tell you that you need not trouble to come after all."

In his younger days, before he was married, the Khoja once shared a house with a certain shoemaker, with whom he was always quarrelling. One morning, after a particularly violent altercation with his companion, he set forth to the 
Defter Khaqani (Land Registry Office), and informed the clerk that he had decided to sell his share of the house.

"What do you want to do that for?" asked the clerk.

"Well," said the Khoja, "this shoemaker is such a quarrelsome fellow that I cannot put up with him any longer. With the money that I shall receive for my part of the house I propose to acquire his share and buy him out."

The Khoja had a cow who gave no milk, so he decided to put her up for auction by the public auctioneer. The next day, as he was walking through the bazaar, he passed the auctioneer, who was leading the cow and calling out, "Who will buy a fine cow, a cow whose milk is like cream ?"

"Dear me!" said the Khoja to himself; " what a lucky thing it is that I heard him say that. I had no idea before that she was such a good milker. I could not possibly think of selling her now."

And, so saying, he took the cow from the auctioneer's hands and led her back home in triumph.

Now the cow had a calf, which the Khoja 


\section{THE KHOJA OF AQSHEHIR}

and his wife used to feed on alternate days. On one occasion the Khoja's wife was invited to a wedding at a neighbour's house, and as it chanced on that day to be her turn to feed the calf, she asked her husband what she had better do.

"I'll tell you what we will do," said the Khoja. "We will arrange that whichever of us speaks first must feed the calf to-day."

"Agreed!" said his wife, and went off to the wedding, leaving the Khoja in the house.

Now it so happened that a band of gypsies had just arrived outside the town, and the gypsy women were roving about the streets, seeing what they could steal. One of them passed by the Khoja's house, and, hearing no sound within, entered and began to lay hands on everything she could find. Presently she came upon the Khoja sitting in the kitchen, but, as he kept silence, she went on dismantling the house. The Khoja making no protest, she became yet bolder, and finally took the Khoja's turban off his head and carried it away with the rest of the booty.

Presently the Khoja's wife returned from the wedding, bringing her husband a dish of 
yakhni (a stew of meat and vegetables) from the feast. When she opened the door and discovered the Khoja sitting bareheaded in the empty house, she cried out aghast, "But, Khoja, what has happened here?"

"You have spoken first," yelled the Khoja in great glee; "you must feed the calf to-day."

In the days of the Sultanate of Rûm, Aqshehir was a town of no small importance, and after the fall of the Seljuq Sultans became the seat of an independent principality until purchased in $\mathrm{I} 38 \mathrm{I}$ by Sultan Murad I., the grandson of the Turkish conqueror 'Osman. Although not as rich in monuments as the greater Konia, it contains among a host of minor buildings of the thirteenth century, an epoch so fertile of works of art in Asia Minor, at least one not unworthy of comparison with the mosques and medresés of the Seljuq capital. This is the Dash medrese, or Stone College, which was erected, as set forth in an inscription over its admirable marble porch, in the reign of. "the great Sultan, the mighty King of Kings, the shadow. of God in the universe, 'Izz 
ud-Dunya ve'd-Din (Glory of the world and of the Faith), the victorious Kai Kaus, son of Kai Khosrau, son of him who is intituled the Proof of the Prince of Believers." The interior of the medrese, singularly reminiscent in plan of a Byzantine basilica, is not, alas, as well preserved as the porch. The court is choked with fragments of stalactite vaulting and ancient capitals, and the mighty arch of marble at its southern end looks in imminent danger of collapse. Along each side of the court runs a row of little cubicles, like the chapels of a Christian church; but a moaning lunatic was the only living thing I saw in the cells of the erstwhile scholars. A mosque was, of course, attached to the college, and its charming minaret of brick still stands beside it, tanned by time and exposure the softest and sunniest of browns. Time has also, however, robbed it of nearly all its tiles of turquoise and sapphire blue; decay has chilled with deadening hand the once thriving university of Aqshehir. No longer do robed and turbaned 'ulema forgather within its portals; no longer do congregations await -in vain - the sermons of Khoja Nasr ed-Dîn. For without doubt 


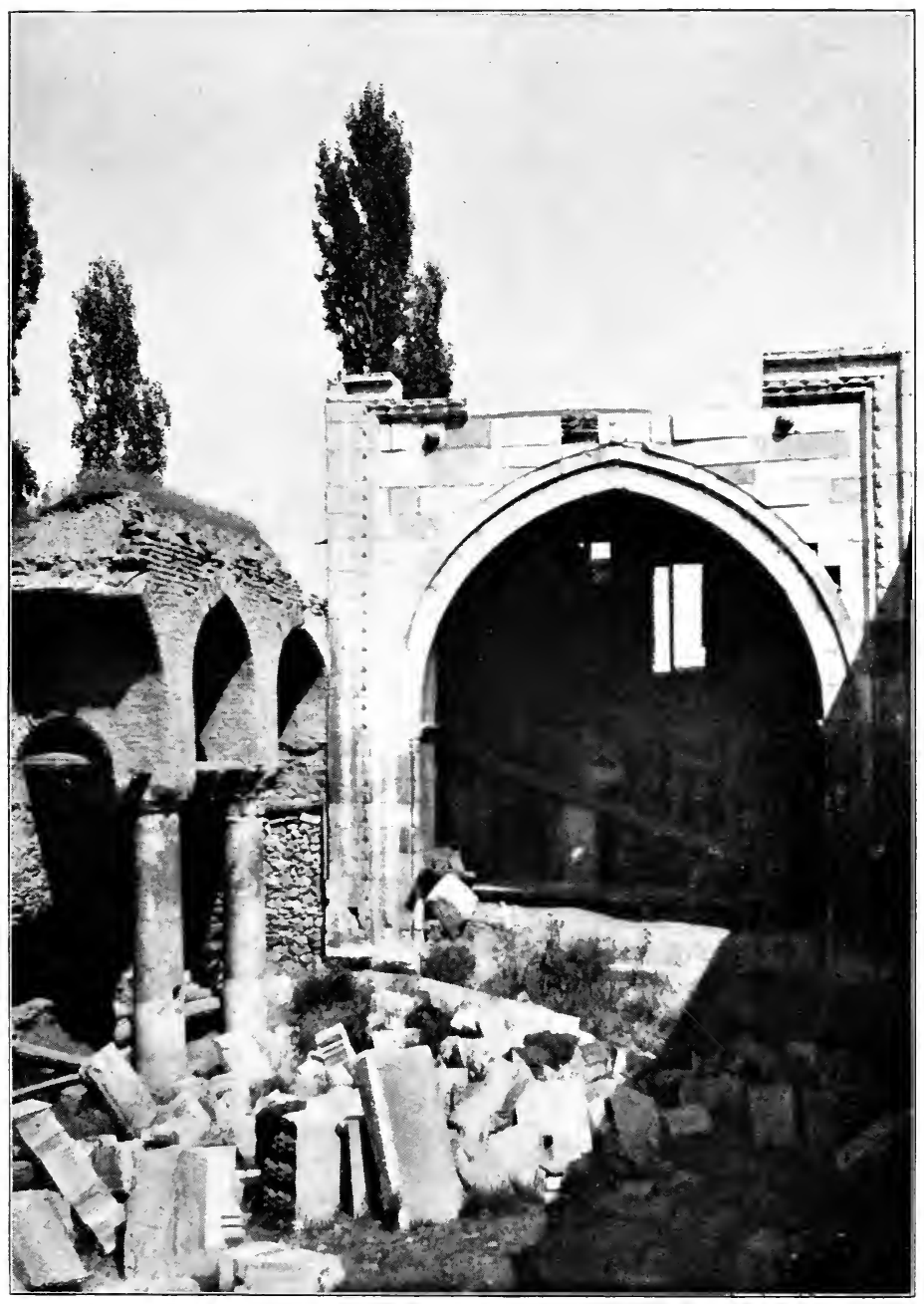

THE DASH MEDRESÉ, AQSHEHIR. 
our Khoja often officiated in this mosque; it is here, I suspect, that he first won fame by his skill in evading his ecclesiastical duties. $\mathrm{He}$ was, poor man, a most unready preacher; nothing did he dread more than the delivery of a sermon, nothing did he more earnestly seek to avoid.

One day he stood up in the pulpit and said to the congregation, "O Moslems, do you know what I am going to say to you to-day?"

"No," replied they.

"And no more do I," said the Khoja, and hastily left the mosque.

The next Friday he asked the same question, but this time the congregation answered, "Yes."

" If you know, then I needn't tell you," said the Khoja, and again made off.

The next week, when the Khoja asked his usual question, the congregation, thinking to display great cunning, said, "Some of us do, but some of us don't."

"Then let those who know tell those who don't," said the Khoja, and once more the congregation were outwitted.

The following Friday, however, they de- 
termined to give the Khoja no chance of escape, and therefore decided that they would say nothing at all, not even return his greeting as he entered the mosque.

"Let us see," said they, "what our Khoja will do."

The Khoja duly appeared and greeted the assembly ; and, in accordance with the arrangement, no one answered him.

"Dear me!" said the Khoja, as he looked round the building, "I am quite alone; nobody has come to mosque to-day."

And with these words he departed, leaving the congregation resigned to do without his sermons.

The Khoja went home, and had just established himself comfortably in his house when he heard some one knocking at the door. He called out to ask who was there, and the man at the door (it was a beggar) called back, "Khoja, come down!"

The Khoja went down and inquired what the man wanted.

Said the beggar, "I want alms."

"Come upstairs with me," replied the Khoja, and, so saying, led the beggar to the top of the 
house. There he turned to him and said, "I have no money to give you."

"A curse upon you, Khoja," cried the beggar, "for making me climb up here if you have nothing to give me."

"And a curse upon you," replied the Khoja, "for having made me come down."

But he was not destined to be left in peace, for his wife aroused him that night from his sleep to ask him to rock the baby.

"It has been crying for the last hour," said she, "and it is your turn now to rock it, as half of it is yours."

"Let my half go on crying," growled the Khoja, as he turned his face to the wall again. "You can go on rocking your half if you want to."

The next day the Khoja arose in the worst of tempers and went to the hamam. An acquaintance came up to him and dealt him a blow on the head in jest, but the Khoja, who was in no jesting mood, forthwith led the man before the Qadi and made plaint.

Now the accused was a friend of the Qadi, and made signs to him in Court that he should give judgment in his favour. The Qadi nodded 
assent, and asked the Khoja in curt and abrupt tones what he had to say.

"This evil fellow, O Qadi," cried the Khoja, pointing to his adversary, "has given me a blow on the head without provocation."

The Qadi reflected for a while, and then delivered judgment.

"For a blow of this nature," he said, "the penalty is one aqché $;^{1}$ and I order the defendant to pay you damages to that amount."

The Khoja's opponent looked in his pocket for an aqché, but, not having so small a coin about him, went out, as he said, to find one. The Khoja waited and waited, and finally became very impatient, but the man did not return. Meanwhile the Qadi had resumed his work, and the Khoja observed that he had lowered his head over a letter which he was writing. Deliberately the Khoja went up to him and struck him a sound blow on the head.

"Dog of a Khoja!" roared the Qadi; " what is the meaning of this ?"

"What else could I do," answered the

1 An obsolete coin which was formerly the smallest monetary unit in Turkey. Its value was one-third of a para, or $\tau^{\frac{1}{2}} \sigma$ of a piastre. 
Khoja, "since my opponent has not come back with the aqché? You can stay here all day, but I cannot; so you had better take the aqché from him when he returns and keep it for yourself."

And with these words the Khoja stalked gravely out of the Court.

Soon afterwards the Qadi died, and another was appointed in his stead. One day the Khoja, who was temporarily performing the duties of Imâm in a neighbouring village, borrowed a donkey from a Jew and refused to return it; so the Jew haled him before the new Qadi. They rode together into town, the Jew on a mule and the Khoja on the stolen beast. It began to rain, and as the Khoja had no cloak, the Jew, who had two, very obligingly lent him his spare one. Plaint was made, and when the Jew had finished speaking, the Qadi said, "O Khoja, why hast thou robbed this Jew ?"

"Robbed this Jew! O Learned among Qadis, $O$ pattern of judges, may thy wisdom ever increase! Hearken not, I beg, to this abominable Jew. I have stolen the fellow's donkey, have I ? Why, he will be saying next that the very coat I wear is his!" 
"Of course it is mine," cried the Jew.

"O Jew," said the Qadi, "thou art a knave, a liar, and a Jew! Get thee gone, and slander no more this just man."

The Khoja returned home in high feather and began to think of himself as somebody, forgetting in his pride to give due glory to Allah; and it fell out that he said to his wife, "To-morrow I sow."

Said his wife, "Insha'llah," which means " if God will." 1

"No," said the Khoja ; "willing or unwilling -to-morrow I sow."

And he set out on his stolen donkey with seed corn; but he happened upon a thunderstorm so fierce and violent that he was swept off the back of the beast, his corn was scattered, and the donkey drowned. When he came home, soaked and wretched, and knocked at the door, his wife called out, "Who is there?"

"I am the Khoja, if God will."

Next day the Jew mocked at him, for his mishap had been reported; wherefore the Khoja, desiring to be even with the Jew, be-

1 "Say not thou of a thing, 'I will surely do it to-morrow,' without "If God will."' Qoran, xvii., 23. 
thought him how to set about it. Now the Jew was a dealer in silk, and the Khoja asked him quite politely if he would buy silk from him.

\section{Said the Jew, "Yes."}

So the Khoja went into the next street, bought some silk of another merchant, and went to where the drowned donkey lay. Having cut off its head, he swathed it in the silk, and bore it to the Jew.

"What a huge bale you have brought!" said he.

"Yes, it is an 'ass's head ' of a lot," replied the Khoja, for the Turks use that word to imply a big bulk. "You will buy, will you not?"

The Jew agreed, and for some time they chaffered about the price. Finally the Jew weighed the bale, and paid for it by the oke.

When he discovered the fraud, he haled the Khoja for a second time before the Qadi and complained of the deception.

"No deception at all!" said the Khoja. "I sold it to him as an ass's head."

One evening, at sundown, the Khoja, who had eaten nothing all day and was very hungry, 
passed a neighbour's house as the neighbour and his family were at meat.

Looking in at the door, he called out, "Peace be with you, O greedy ones!"

They answered angrily, "By Allah, we are not greedy!"

"May the Prophet grant," said the Khoja, "that I am the liar, and not you."

Whenever he had anything to give, however, the Khoja was an hospitable soul, and people sought at times to take advantage of his known kindness of heart. One day a peasant brought the Khoja a hare. He was warmly welcomed, and invited to partake of the hare at dinner. The next week the peasant returned, without a hare, but was again hospitably received. The following week several strangers arrived at the house and asked to be entertained.

"Who are you ?" inquired the Khoja.

They explained that they were the neighbours of the man who had brought the hare; and they were given something to eat.

A few days later a large gathering of people appeared at the Khoja's house demanding hospitality. The Khoja asked them who they were, and was told that they were the neighbours 
of the neighbours of the man who had brought the hare.

"Welcome!" said the Khoja, and set cups of water before them.

"How now, Khoja," exclaimed the strangers ; "what is this water that you have given us?"

"That is not water," replied the cunning Nasr ed-Din ; "that is the sauce of the sauce of the hare."

Shortly after this episode the Khoja cooked a dish of tawa (roast pieces of mutton and onions) for his supper. Just as the tawa was ready, two neighbours came in unasked and began to eat with him.

One of them took a large helping of meat from the tenjere," and said, "This meat requires salt."

The other also helped himself generously to the mutton, and, after tasting it, remarked, "This meat requires pepper."

Hastily the Khoja removed what was left, saying, "This tenjeré requires meat."

But he determined to be even with his greedy friends, and on the following day asked one of them for the loan of the largest of his tenjerés.

1 Saucepan. 


\section{THE KHOJA OF AQSHEHIR}

The man agreed, and the Khoja took the tenjeré home and kept it. After some weeks had elapsed, the owner began to feel a little uneasy about his tenjere, and asked the Khoja to return it.

"You cannot have it yet," the Khoja informed him; "for it has just given birth to young, and is not yet well enough to be moved."

The man went away in amazement, for he had never heard before that tenjerés were wont to have young. Shortly afterwards, however, he was surprised and pleased to receive, with the Khoja's compliments, a tiny tenjeré and a message to say that it was the pick of the litter and that the mother was doing well. Two days later his own tenjeré was duly returned to him.

The following year the man begged the Khoja to borrow the saucepan again, and to superintend the arrival of another family. The Khoja consented, and for some time his friend waited for the tenjere to appear with her new brood, but in vain. Eventually he knocked at the Khoja's door and asked for news of the tenjeré.

"Alas," said the Khoja with a doleful air, "your tenjeré is dead." 
"Dead!" cried the man angrily. "You rascally Khoja, you know very well that tenjerés do not die."

"They die as surely as they have young," said the Khoja; " and if you believe the one, why should you not believe the other?"

Khoja Nasr ed-Dîn once had a lamb, which his friends conspired to obtain by a ruse and eat. They arranged that one by one they should go to the house of the Khoja and tell him that the end of the world was at hand; and suggest to him that they should make merry together on their last day and eat the lamb.

The Khoja paid no attention to the first and second who came with this tale; but in the end, after they had all come, he appeared to believe it, and agreed to join the party and provide the lamb.

So they went off into the country and sat down near a stream. And as it was a hot day, the Khoja said to his companions, "Do you, my friends, go and bathe in the stream while I make ready the lamb."

They thought the suggestion a good one, and, leaving their clothes with the Khoja, went 
down to the water. No sooner were they out of sight than the Khoja lighted a large fire and threw their clothes on to the flames.

Presently one of the bathers said to the others, "Let us go back now and see if the Khoja has finished roasting the lamb."

They returned to find their clothes in ashes, and furiously demanded an explanation of the Khoja.

"But surely," protested he in astonishment, "you were not joking when you told me that the end of the world was coming to-morrow? I wanted some fuel for the fire, and naturally used your clothes, for what need will you have of clothes in the next world?"

On the next market day the Khoja proceeded to replace the lamb, and set out for the bazaar with two of the friends who had suggested the feast. Between them they bought a couple of lambs and a ram, for which each paid an equal share. As they were driving their purchases home, the Khoja was asked by one of the others how they should divide them.

"That is easy," said the Khoja. "You two will take one lamb, and the ram and I the other."

This saying became well known in the town, 
and soon afterwards the Khoja's assistance was invoked by three men who were quarrelling about their shares in a sack of walnuts.

"O Khoja, come and help us," said the first, "for we cannot agree upon the division of these walnuts among us three. Make thou the division."

"Yea, divide with absolute justice!" said the second.

"Nay, justice even is not enough," said the third. "Divide as Allah would divide."

The Khoja agreed, and took the walnuts. "Then am I to make division as would Allah?"

"Yea, as would Allah," said all three.

Whereupon he gave one walnut to the third man, and a handful to the second man, and all the rest to the first.

"How now, Khoja, what is this? Dost thou call this an equal division?"

"O fools, when did Allah divide anything equally among men? As would Allah, so have I divided."

With one more tale will I bring these examples of the Khoja's folly and wisdom to a close. A great man once gave a feast, to which, with much condescension, he caused the Khoja 
to be bidden. Accordingly, on the appointed day the Khoja repaired to the great man's house, and found himself in the midst of a fashionable and richly clad assembly which took no notice of the poor Imâm in his threadbare black gown. No one greeted him or spoke to him, and eventually he was shown by a servant to the lowest seat. After a little while the Khoja slipped away unobserved, and went into the hall where some of the mighty ones had left their outer garments. Selecting a magnificent gown richly lined with fur, he put it on and returned to the room. Nobody now recognized as the Khoja this resplendent personage whose arrival excited universal attention. The company rose to salute him, and the host, who had previously ignored him, approached bowing, and inquired after his honourable health.

The Khoja stroked the sleeve of his borrowed garment.

"Answer, fur!" he said. 


\section{BIBLIOGRAPHY}

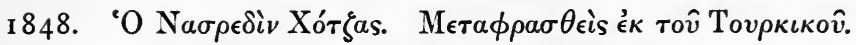

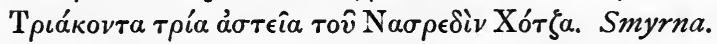

1853. Anton PanN. Nazdravaniile lui Nastratin Hogea (Rumanian). Bucharest. New edition, I909.

I854. W. B. BARker. A Reading Book of the Turkish Language, with a Grammar and Vocabulary, and pleasing tales of Khoja Nasr-il-deen Effendi. London.

F. Dieterici. Chrestomathie ottomane. Berlin.

N. Mallouf. Dialogues turcs-français . . a augmentés de neuf anecdotes amusantes, etc. Sinyrna.

Do., Plaisanteries de Nasr-Eddin Khodja; texte turc et traduction française. Ibid.

1856. Do., do., another edition. Constantinople.

1857. W. von Camerloher and W. Prelog. Meister Nasreddin's Schwänke, und Räuber und Richter. Aus dem türkischen Urtext wortgetreu übersetzt. Trieste.

Nasradin iliti Bertoldo i njegova pritanka domisljatost, himbenost i lukavstina (Croatian). Zara.

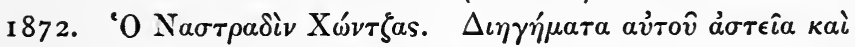
$\pi \epsilon \rho i \epsilon \rho \gamma \alpha$. Athens.

1876. J. A. Decourdemanche. Les Plaisanteries de NasrEddin Hodja, traduites du Turc. Paris.

1878. Do., Sottisier de Nasr-Eddin Hodja . . ., suivi d'autres facéties turques, traduits sur des manuscrits inédits. Brussels.

"Murad EFEnd " (F. von Werner). Nassr-eddin Chodja. Oldenburg. 
I 884. G. BORROW. The Turkish Jester; or, the Pleasantries of Cogia Nasr-Eddin Effendi. Translated from the Turkish. Ipswich.

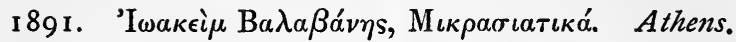

1894. N. ARratoon. Gems of Oriental Wit and Humour, or the Sayings and Doings of Molla Nasraddin ... Translated from the Persian. Calcutta.

I 899. Dr. I. Kunos. Naszreddin hodsa tréfái . . Török (Kisázsiai) szövegét gyüjtötte, forditással és jegyzetekkel (Hungarian and Turkish). Budapest.

190I. Sir JAMES WhitTall. Frederick the Great on Kingcraft, with Reminiscences and Turkish Stories. London.

1903. Nasradin-hodza njegove sale, dosetke i lakrdije $u$ pripodjetkama od Mehmeda Tevfika (Servian). Neusatz.

Nasradin $\mathrm{k}$ staroj matici povracen i Nasradinic (Croatian). Zara.

1904. "AlI NouRI." Nasreddin Khodjas Schwänke und Streiche. Breslau.

1908. J. A. Decourdemanche. Les Plaisanteries de NasrEddin Hodja, traduites du Turc, augmentées des Naīvetés de Karacouch. Paris.

19I1. A. Wesselski. Der Hodscha Nasreddin. Weimar. No date. Posurice i sale Nasredina (Croatian). Agram.

Turkish editions in A.H. I 253 (A.D. 1837), 1254, $1257,1259,1264,1266,1325-1327$.

Turkish editions in Armenian characters in A.H. 1259 and 1264 . 
III

SOME ASPECTS OF ISLAM IN TURKEY 



\section{SOME ASPECTS OF ISLAM IN TURKEY}

Recently, in one of the remoter corners of the Ottoman Empire, I rode to a little tekye, or dervish convent, which lies in the open country about two Turkish miles (leagues) from the principal town of the district, in one of those rich agricultural plains which abound within the Turkish dominions. I do not know if the tekyé in question ever housed a dervish community of any magnitude; probably not, to judge from its limited accommodation. At the present time its only occupants are an old Sheikh of the Naqshibendi Order and his elderly assistant; and it is rarely visited except on the one day in the year when pilgrims, mainly of the peasant class, come to venerate the tombs of the forty holy Sheikhs which are ranged in two parallel 
subterranean corridors underneath the mosque. It is no unusual thing in the Levant for a shrine, or grove, or sanctuary to be revered by the followers of more than one faith. Not only do we find seven branches of Christianity in the Church of the Holy Sepulchre, and the four Suni schools in the Omayyad Mosque of Damascus. The pit shown as that into which Joseph was cast by his brethren is venerated by Christians, Moslems, and Jews; Moslems possess a mikrab in the Church of the Tomb of the Virgin in Jerusalem; in Anatolia the Saint George of the Christians and the Sheikh Khidr of the Moslems are one. The tekye, too, is an example of this phenomenon; and if history is silent as to the origin of its forty Sheikhs, report is very full of their supernatural activities at the present day, activities which annually attract not only the pious Mohammedan, but also the Christian devotee. He who, waxen taper in hand, passes fearfully and devoutly from one green and turbaned tomb to another is regarded by them with tacit approval, whatever his religious convictions may be ; but woe to the sceptic who has come to scoff and jibe. I have seen the sword which, wielded by 
no visible arm, cut off the head of a Greek priest who derided the powers of the Sheikhs ; firmly embedded in the rock at the extreme end of the left wing of the tomb-galleries is a spike which by similar means most severely goaded another doubter. Consequently the Forty are regarded with awe by surrounding villages of either faith; and their wonder-working tombs provide ample material for the superstitions which are dear to the unlettered peasant of Turkey.

I visited the shrine, not on the occasion of the annual pilgrimage, but on a day when the old Sheikh had bidden certain fellow-dervishes from the town to participate with him in a celebration of the $z i k r$ of their Order. Zikr, literally a "remembering," or "commemoration," ${ }^{1}$ is the name given to the peculiar ritual of dervishes, which, assuming different forms in the different Orders, is designed to divert the minds of the votaries from earthly things, bringing them into closer communion with the Divine. Thus, in the Mevlevi sect, it takes the form of dancing, or rather, of whirling round

1 Qoran, xxxiij., 4I : "O Believers! Remember God with frequent remembrance, and praise Him morning and evening." 
as far as possible on the same spot; in the Naqshibendi and Rufa'i it consists of the repetition of certain religious formulæ, which are persisted in until the requisite state of ecstasy, almost invariably followed by severe exhaustion, is brought about. The members of the two latter Orders are vulgarly known, in consequence, to Europeans as Howling Dervishes, and in the severer forms of their zikr they not infrequently, on attaining a condition of exaltation, inflict wounds upon themselves with swords, skewers, and other forbidding instruments of torture. The state of ecstasy appears to render them impervious to pain, and it is a remarkable fact that it is easily attainable not only by professed and practised dervishes, but by the numerous lay brethren who, drawn from every class of Turkish society, form an important addition to the official or permanent dervish ranks. It is also, I believe, true that if two or three Turks, believers, but in no special degree devout or acquainted with dervish practices, sit down togetherand, swaying their bodies from side to side, repeat with concentration the formula of some $z i k r$, they very often arrive at the condition which such exercises produce in dervishes. 
The Sheikh of this particular tekyé enjoyed a considerable reputation among his brethren for the severity of the tortures which he was wont to inflict upon himself when stimulated by the zikr. Gaunt and old, with a shaggy white beard, wild eyes, and a childlike smile, he looked his part to perfection, and entered with the utmost zest into the preliminaries of the service. The dervishes squatted in a circle on the floor of the mosque, and with marked and peculiar rhythm began in guttural unison to invoke the Almighty. "Ya meded, ya Allah, ya meded, ya Allah!"- “ Help, O God!"-they repeated, swaying gently from side to side. Presently the invocation and the rhythm changed. Bowing their heads at the end of each sentence, they exclaimed, louder and more quickly, "La ilaha illa'llah, la ilaha illa'llah!"- "There is no god but God!"-laying heavy emphasis on the two final syllables. After a while they exchanged this exercise for the mystic words " $Y a$ Hu!"- "O He!" (i.e., O God!) -and shouted them with a guttural violence that closely resembled a bark. Their swayings were now very rapid, and had grown so agitated that they were able, without abandoning their 
squatting position, to jerk themselves along the floor, the sweat pouring from their brows. Suddenly, with a wild shout, and with an unearthly look in his eye, the old Sheikh jumped up and tore off all his garments except a pair of white cotton drawers and his green turban. He seized a sword which lay in readiness, and, pressing its sharpened edge against his naked body, endeavoured to run forward while two of his companions held him back by the extremities of the sword. He had attained the state of hal, or ecstasy, and was oblivious of earthly things. Still breathlessly shouting " $Y a H u$ !" while the spittle ran down his beard, he now possessed himself of a long skewer weighted at the top by a wooden ball from which dangled pieces of chain. He pulled the skin of his chest out to its furthest extent, and, after twirling the skewer several times in his hand, plunged it through the skin without drawing blood. Next, he licked a fire-iron which had meanwhile been heated in a manqal, or charcoal brazier, to the accompaniment of the shouts and heavings of his fellows. One of these, a negro, now lost all control of himself. Throwing off his turban, he beat his head repeatedly and violently against 
the hard mud floor, while the colour of his face turned from black to an ashy grey. His neighbour clasped him round the shoulders, and soothed him by blowing and spitting in his face. No sooner, however, had he done so than he himself caught the infection, to be calmed in his turn by the now peaceful negro.

By this time the climax of the performance had been passed, and the zikr ended ere long in a diminuendo of noise and movement. The invocations of the dervishes became less loud and rapid, their swayings gentler; eventually they subsided into weary but contented calm. ${ }^{1}$

From this description it might perhaps be inferred that Turkish dervishes were hysterical revivalists, men whose religion took the form of inducing violent but superficial and transient emotions. It is one of the curiosities of Islam that such is not the case. There is a certain resemblance between the excitement of the revivalist and the hal of the dervish, but it is limited and deceptive. The hal neither interrupts nor impairs the staid dignity of the

1 For an analysis of the inward significance of the $z i k r$ (according to the Rufa'i tariq), see the Rev. H. T. Gairdner's interesting article, "The 'Way' of a Mohammedan Mystic," in The Moslem World, vol. ii., 1912. 
dervish, nor does it, in passing away, carry with it any part of his religious ardour or convictions. Dervishes represent that element in Mohammedanism, and it is no inconsiderable one, which seeks a wider sphere, not only for its religious emotions, but also for its religious speculations, than that generally afforded within the rigid and austere confines of orthodoxy. Thus we find that, while on the one hand their emotional side finds an outlet in the zikr, on the other their speculative or reasoning qualities lead them into what is often an advanced form of mysticism. This, with their anxiety to protect their religion from deadening encumbrances, causes them to be looked at askance by narrowminded and fanatical 'ulema of the old school, by men who think that the devil speaks along telegraph wires, and who gave to the bicycle the name it still bears among country folk, that of sheitan 'arabasi, or "Satan's cart." Again, the wideness of their views as regards Islam is extended to their attitude towards other religions ; and thus the dervish is both a member of an esoteric Moslem confraternity and the most tolerant of Moslems. He is ready to see good in all religions, and dislikes religious persecution. 


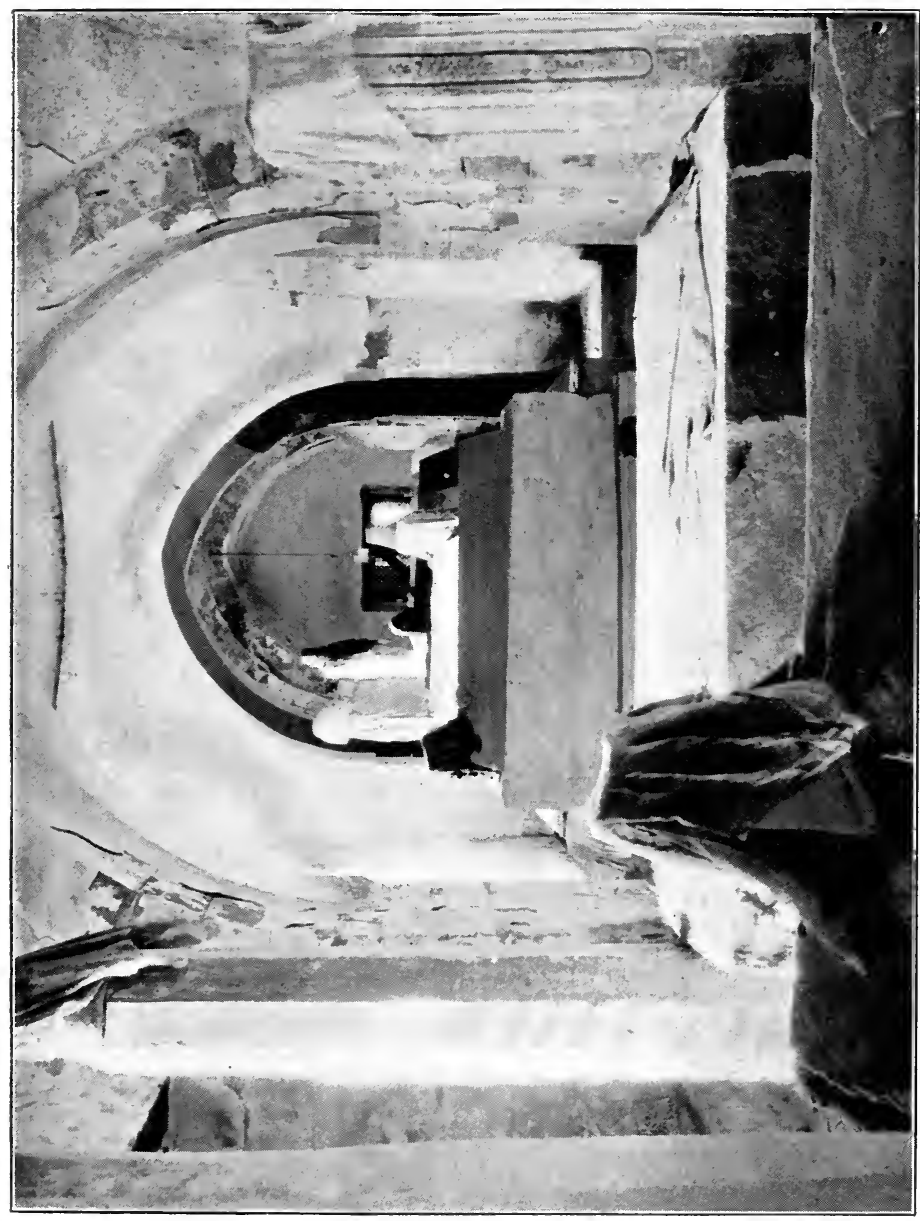

¿̊

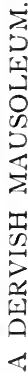




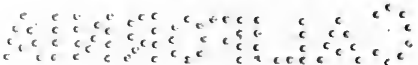


In his memorable book Turkey in Europe Sir Charles Eliot relates having heard on good authority that "in the dangerous period in the winter of $1895-96$, when religious and national feeling ran high in Turkey, it was mainly owing to the Mevlevis that the Softas of Konia were prevented from attacking the Christian population of the town." Sir E. Pears ${ }^{1}$ quotes a Bektash Sheikh as saying that there was nothing in Christianity which need prevent a man from becoming a good Bektash.

The Mollah or Softa who believes that the telegraph conveys the voice of Satan is not, however, much in evidence in these days, nor does his opinion carry great weight. 'Abdu'l Hamid, in pursuit of his centralizing policy, covered even the most distant vilayets with so extensive a network of telegraphs that the wires suggest to the majority of Turks the Padishah's voice rather than the devil's. Nevertheless, the Turks, as being more closely in touch with European nations than other Moslem races, have suffered much from the rigidity of Islam. By making the Qoran a code of law as well as a book of spiritual revelation, and

1 Turkey and its People, London, 191 I. 
by legislating therein so minutely that man's every action is regulated and prescribed, Mohammed has rendered it exceedingly difficult for his followers to adapt themselves to the needs of an age whose circumstances he did not foresee. The precision of his injunctions is certainly beneficial in that it leaves no room for doubt in the mind of the devout Moslem as to what his course of action in a given case should be; it is an effective and invaluable instrument in the mission field. The coherency and thoroughness of the Qoran, says Sir Charles Eliot, give Islam as a Church militant "an unequalled power of converting, drilling, and disciplining savage nations. But the same characteristics become a source of weakness in the religion of a great state in contact with European Powers." Turkish organization has not been successful in the administration of provinces inhabited principally by non-Moslems, although it has been admirable for purposes of conquest. Recognizing all this, it is still possible for us to exaggerate the extent of the barrier which Islam opposes to progress. In the sixteenth century it did not prevent the Turkish artillery from being more advanced 
and efficient than that of Western nations; lately it has enabled 'Abdu'l Hamid to carry out, under purely Moslem auspices, the construction of the Hejaz Railway.

No discussion of the merits and demerits of Islam would be complete without a reference to the status of women in the Moslem world, but on this point, as on others, there have been many misconceptions. Without assuming that a book like Les Désenchantées correctly portrays the feelings of the majority of Turkish women, we may readily admit that their position is in need of improvement. Let us inquire, however, before we condemn Islam on that account, what are the advantages of the present system that may be set against its disadvantages, and, further, how far Islam is responsible for the latter. One weighty item stands to its credit side: that it is practically a complete check on prostitution. The Turkish Government does not figure among the signatories to the International Convention of I9Io for the suppression of the White Slave Traffic; on the other hand, among prostitutes in Turkey representatives of the millet of Islam are conspicuous by their rarity. And if divorce is much too easy, such 
is sometimes the case in non-Moslem countries. The origin of the seclusion of women is not Moslem. Historically it is pre-Mohammedan, and the limits within which it was and is observed are geographical, not religious. Mohammed found the system in existence in Arabia, and retained it with certain modifications. It is permissible to criticize him for not abolishing it; it is clearly wrong to saddle him or Islam with its invention. Faint traces of survivals of the system may still be met with in Christian countries bordering on the Mediterranean. Jealous husbands do not, it is true, there confine their wives to the guard of Ethiopian mutes; but the tendency in parts of those countries for women to go about in dressing-gowns until the afternoon smacks somewhat of what we are told is the mode of life of the harem. The patios of Andalusian houses are probably the result of Arab influence; but no one can attribute the women's galleries in Byzantine churches to imitation of the Moslem. Christianity has whittled down, and in many cases obliterated, such restrictions as it found upon the freedom of women; Islam has not; and that is the extent of Mohammedan responsibility in the matter. 
The salutary disciplinary effect of the Qoran has already been alluded to. Islam, which means resignation, inculcates, as regards man's relations with the Deity, patient submission to the predestined will of God; hence it consecrates, in man's relations with the State or his fellowmen, obedience to properly constituted authority. To the nature of their religion the Turks, primarily a military race, owe the discipline which has been, in the course of their history, perhaps the greatest asset of their armies. Again, the absence of sacerdotalism, the non-interposition of an intermediary between God and man, foster in the individual Moslem a self-respect, a sense of personal responsibility to which are due the enterprise and initiative of the Turkish soldier in warfare. In the theocracy of Islam no priestly caste acts as man's mediator with his Maker. The Imâm is only the leader of prayer, a sort of precentor; the 'ulema, as students of Qoranic law, which mingles Civil with Canon law, are at most but semi-ecclesiastics. And as the Turk learns to respect himself, so he learns to respect his elders and betters, and not to withhold all respect from those fellow-Moslems, such as beggars, 
whom he cannot regard as his betters. For parental authority he entertains a deep regard. A grown-up Turk who is lax enough to drink wine or raqi will usually hesitate to do so in the presence of his father; similar diffidence is even shown, sometimes, with regard to smoking. Near relationship does not engender what the Turks regard as unseemly familiarity: Turks address their elder brothers by the titles of agha or agha beyi, their elder sisters as abla, scarcely ever by name unless the difference in age is very slight. They obey seriously the injunctions of their faith as to charity. Wealthy men will endow schools, equip some village with a water-supply, defray the expenses of an indigent pilgrim to Mecca, feed a certain number of poor from their kitchens every Friday. At the feast of Qurban Bairam they send gifts of mutton to their poorer neighbours. Those less opulent buy bread for the street dogs, give doles of food to beggars who call from house to house, pay for the contents of a goatskin of water to be dispensed free to all who ask. The solidarity of Islam does not permit them to suffer co-religionists to starve. 
Furthermore, they do not blaspheme. In anger they may allude in unflattering terms to the ancestry, or to the virtue of the female relatives, of their provoker ; they have too profound a respect for the name of God to couple it with coarse abuse. Another of their traits is kindness to animals, although this sometimes takes an illogical form, as when they allow puppies and kittens to die of exposure because they dislike drowning them. And the toleration they can display toward Christianity when it is not in real or fancied conflict with their own interests is remarkable in view of the exploitation which they have undergone at the hands of foreigners. It would not be unreasonable to suppose that they would eradicate from churches that had been turned into mosques all vestiges of Christian worship and decoration. In S. Sophia in Constantinople only the faces of the great angels in the central dome have been whitewashed; when I visited Salonika in 1907, the Byzantine mosaics of the superb basilica of Hagios Demetrios, the Qasimieh Mosque of Turkish times, were being restored at the expense of the Ottoman Government; in the principal mosque of 
Cyprus, that of S. Sophia in Nicosia, the architectural chef d'cuvre of the Lusignan kings, not only carved crosses but the Christian appellation have been suffered to remain. It is difficult to say what would be done in Christian countries in the converse case, as mosques of high importance are rarely turned into churches. I have seen one or two small churches in the old "Banat" which were formerly mosques, but no monograms of the first Khalifs, or other Moslem emblems, did I discern. Such tolerance, of which examples can be multiplied, and the laudable attitude of the dervishes, are characteristic of the best type of Turkish Moslem.

There is, however, another form of tolerance which is not so healthy a symptom, because it is inspired less by respect for other religions than by indifference to Islam. The religion of the Turk brings out all that is best in him, encourages the fundamental Turkish virtues of sobriety, truthfulness, honesty, cheerful obedience, patierce, and endurance. W. G. Palgrave, an exceptionally shrewd student of Turkish character, wrote in 1870 : "A workman, who, in an ordinary way, cannot be got to 
make two windows on a line in the same length of wall, or make level the floor of a room ten feet square, never fails to direct the 'Kibleh' niche with unerring exactness, and to find to a hair's breadth the precise angle of the radius that points to Mecca. What love is to the world at large, that is Islam to the Eastern; it renders him architect, poet, metaphysician, carver, decorator, soldier, anything. Taught by Islam, men who even in the long-drilled regiment can never dress a line or form a square with tolerable correctness, range themselves in the most perfect rank and file at the hour of prayer. . . Every feature of the village tells the same tale. The cottages are the merest hovels-we here except Syria-half earth, half rubble; and no pretence, not to speak of ornament, but even of common symmetry and neatness, relieves their ugliness. Even the Beg's house is a clumsy barrack, sadly in need, too, of repair : its decorations are of the simplest and cheapest kind. But on the village mosque neat stone-work, subtle carving, elaborate art have all been lavished; here the injuries of time are immediately and accurately made good; here are to be found the best 
carpets, here the gayest colours, here the most scrupulous cleanliness."

It is Islam which, notwithstanding its faults, its rigidity, its stationary tendencies, has made the Turks a great people; it is Islam which has inspired a small and obscure Siberian tribe with the ardour and organization that enabled it to establish one of the widest Empires of modern history. The extent to which the decay of that Empire is attributable to decay of faith among certain classes of Turks is not easy to define with precision, but it is considerable. There is no truer saying in Turkey than the proverb "Baluq bashdan qoqar," which means "Fish first stinks at the head." Among the agricultural population, those who wear the Turkish peasant dress of embroidered yelek and baggy breeches, and are known in consequence as baldiri-chiplaqlar, or "barecalves," Palgrave's observations still hold good. The Turkish countryman is an honest, upright soul, and wisely clings to the religion which is his protection against the vices of the West and the degenerating poisons of the town. But in Constantinople, the capital of the Empire, irreligion and indifferentism have long 
been rife among the upper classes; and in 1784 one Elias Habesci, ${ }^{1}$ an able and far-seeing Levantine, wrote as follows concerning what he then regarded as Turkey's precarious position:

"An enquiry, then, how far the modern Turks have deviated from the original institutes of their founder cannot but be highly interesting, as it will lead to an explanation of the causes of the present humiliating situation of a once formidable power, whose arms were dreaded in former times by some of the most respectable states of Europe, and their alliance courted by others."

And, in the same chapter, Habesci's ascription of Turkish defeats to the fact that " neither soldiers nor officers any longer believe that they shall go to paradise, from being slain in the field of battle," is a curious anticipation of what has been stated to be one of the principal causes of Turkish disasters in the recent war.

1 The Present State of the Ottoman Empire, etc., London, 1784. 

IV

THE TURKISH KHALIFATE AND

ITS ORIGIN 



\section{THE TURKISH KHALIFATE AND ITS ORIGIN}

When Sultan 'Abdu'l Hamid II. ascended the throne of 'Osman, many competent students of Turkish affairs were of opinion that the fall of his Empire was approaching. They saw that signs of disintegration were manifest on every side; they could almost hear the death-rattle in the "Sick Man's" throat. Indeed, 'Abdu'l Hamid suffered, during his reign, the loss of many provinces; since his deposition he has lived to see the loss of many more. In spite of these blows, blows that might well have killed a state differently constituted, 'Abdu'l Hamid left Turkey a greater power than he found it; and the instrument with which he performed this astounding operation was the Khalifate. The astute sovereign, realizing the 
necessity of retrieving in other directions what Turkey had lost and was losing in material power, decided to exploit the moral power of the Khalifate, until then more or less latent, and to develop the theory of a united Islam under the leadership of the Khalif in Constantinople. It remains to be seen how far he has been successful. The power of the Khalifate to-day is exaggerated by some, derided by others, precisely estimated, possibly, by none. Yet it is an element in international politics which cannot be ignored; and the aim of this chapter is to trace its genesis and journey along the intricate steps by which it has passed from Abu Bekr to Mehmed V., as well as to explain by what classes of Moslems it is, and is not, accepted.

The Prophet Mohammed had paved the way for, had, in fact, created, a spiritual and temporal monarchy embracing all true believers, in which spiritual and secular authority was concentrated in the hands of one person, the Khalif, a word meaning successor, lieutenant, or vicar. But Mohammed, who left no son, had omitted to decide positively who his successor was to be; and, on his death, angry disputes arose as to the selection of the first 
Khalif. The most prominent candidate was 'Alî, nephew of Mohammed and husband of his favourite daughter Fâtima, who would probably have been elected but for the opposition of the Prophet's widow Ayesha. "The Mother of the Faithful " was a woman of great influence in Mecca and Medina, and to the end of her days a bitter enemy of 'Alî, who had supported an accusation of adultery against her. She induced the Moslem notables to set him aside and to choose her father Abu Bekr; and Abu Bekr, after reigning for two years, was succeeded by his nominee 'Omar, and 'Omar by the feeble, imcompetent 'Othman. Under the first three Khalifs the all-conquering Arabs carried Islam into Syria, Persia, and Egypt ; but 'Othman prepared the way for the disruption of the new Empire by appointing as Governor of Syria one Mu'âwiya, of the powerful Omayyad family, the son of the Prophet's arch-enemy, Abu Sofian. This and other impolitic acts brought such unpopularity upon 'Othman that he was murdered in 655 ; whereupon 'Alî finally became Khalif, and also, unconsciously, the rock upon which Islam split into its two principal divisions. 
The first step towards schism was Ayesha's refusal to acknowledge the new Khalif, a refusal also maintained by Mu'âwiya. Mu'âwiya alleged as his reason 'Alî's omission to punish the murderers of 'Othman. In point of fact, he himself had designs upon the Khalifate; and with the support of the Syrians resisted by force 'Alî's demand for his submission. In the meantime, the political centre of gravity of the Mohammedan Empire had shifted from the two holy cities of the Hejaz. 'Alî, turning for support towards Persia and Iraq, concentrated his forces at Kufa in Lower Mesopotamia; while the headquarters of Mu'âwiya were at Damascus. The civil war which ensued was more than a personal or dynastic struggle; it represented the struggle between the Syrian and the Persian elements, the Semite and the Aryan, for the dominant position in the Moslem world. In 66I, after five years of war during which he steadily lost ground, 'Alî was murdered at Kufa; whereupon his son Hasan, much against the wishes of his younger son Husein, abandoned the contest by resigning his claims to Mu'âwiya. The latter was now sole Khalif, and the Mohammedan world once more 
politically united, for the present under the leadership of Syria. Spiritually, however, the breach between the two parties grew ever wider ; and in Persia 'Alî became posthumously the object of veneration far greater than that which he had enjoyed in his lifetime, became, in fact, the central figure of that branch of Islam which is known by the name of Shi'a. ${ }^{1}$ $\mathrm{He}$ was soon believed to be an incarnation of the Divine Spirit, as great as, if not greater than, Mohammed himself, and the latter's immediate successor; the Shi'as regard Abu Bekr, 'Omar, and 'Othman, and especially the Khalifs of the Omayyad Dynasty founded by Mu'âwiya, as heretics and usurpers.

The other principal division of Islam takes its name from the Suna, or "Tradition," which grew up, as a complement to the Qoran, under the Omayyad Khalifs. The Suna consists in part of miracles and other acts performed by Mohammed, but includes precepts and regulations issued by the Khalifs, which made it unacceptable to the Shi'as. Whatever stress, however, may be laid upon the doctrinal questions on which Suni and Shi'a divide, it

1 Arabic shi' $a$, a religious heresy. 
cannot be doubted that the fundamental cause of the breach was a national or racial one. Religious differences have no doubt been intensified, in a measure, in the course of years, but their importance at the time of the schism is not inaccurately represented in the words of Tom Moore's Persian Visitor:

You know our Sunnites,- - hateful dogs

Whom every pious Shiite flogs

Or longs to flog-'tis true, they pray

To God, but in an ill-bred way;

With neither arms, nor legs, nor faces

Stuck in their right canonic places!

'Tis true they worship Ali's name-

Their Heaven and ours are just the same-

(A Persian's Heav'n is eas'ly made, 'Tis but-black eyes and lemonade).

Yet-though we've tried for centuries back-

We can't persuade the stubborn pack,

By bastinadoes, screws, or nippers,

To wear th' established pea-green slippers!

Then-only think-the libertines!

They wash their toes-they comb their chins-

With many more such deadly sins!

And (what's the worst, though last I rank it)

Believe the Chapter of the Blanket!

Yet, spite of tenets so flagitious,

(Which must, at bottom, be seditious,

Since no man living would refuse

Green slippers, but from treasonous views;

Nor wash his toes, but with intent

To overturn the Government !)- 
Such is our mild and tolerant way,

We only curse them twice a day,

(According to a Form that's set),

And, far from torturing, only let

All orthodox believers beat 'em,

And twitch their beards, where'er they meet 'em.

The Omayyad Khalifate was brilliant but short-lived. Luxury, indulgence, and "Syra mollities" reigned at the Court of Damascus in the place of the primeval simplicity of the desert; the patriarchal administration of the early Khalifs disappeared before the mass of new political and economic questions brought into being by the extension of the Empire. The Khalifs generally ignored the religious side of their office; the proselytism of Christians was discouraged because of the additional taxes which were paid by non-Moslems. In $75^{\circ}$ the 'Abbâsids, descendants of the Prophet's paternal uncle 'Abbâs, overthrew the Omayyads and established the seat of the Khalifate at Baghdad. Here they reigned until I258, when the Mongol Hulagu captured Baghdad, and the eastern Khalifate, as a state, expired.

I use the expression "eastern Khalifate" advisedly, because, soon after the advent of the 'Abbâsids to power, the character of the 
Khalifate underwent two vital changes. In the first place, the theory of a sole Khalif at the head of the entire Moslem world was contradicted in practice by the rise of an Omayyad (Suni) Khalifate in Spain, and of a Fâtimite (Shi'a) Khalifate in North Africa. On the fall of the Omayyads a member of the family, 'Abd er-Rahman, grandson of Khalif Hisham, escaped the fate which overtook nearly all his relatives, and fled to the Sahara. Constantly pursued by order of his enemies, the 'Abbâsids, who desired completely to exterminate the Omayyad race, he maintained a precarious existence by passing from one tribe of the desert to another. Meanwhile the Arabs in Spain, weary of the internal disorders caused by the selfish ambitions of their petty Emirs, had decided to end local dissensions by the creation of a separate Khalifate in Moslem Spain, since the bonds between Spain and the Khalif in the East had become so loose that the latter was no longer a reality in the Peninsula. On account of his illustrious descent the fugitive Omayyad was selected for the dignity, and accepted it from a deputation which sought him out in his African hiding- 
place. He landed in Spain in 755, and the western Khalifate which he inaugurated endured until the fall of Granada in I492. ${ }^{1}$ The Fâtimite Khalifate was of slightly later origin. The Fâtimite Khalifs, so called from Fâtima, the Prophet's daughter, belonged to the Isma'ilîyeh sect of Shi'as, and claimed to be descended from the Imâm Isma'il, seventh in descent from 'Alî, of whom more will be said hereafter. The first Fâtimite Khalif, 'Obaidallah, professed to be the Mahdi, and founded his capital, which was accordingly called Mahdia, in what is now Tunisia; in 972 the fourth Fâtimite, Mo'izz, entered Cairo, which thereafter became the seat of the Fâtimite rulers. In I I I Saladin put an end to the sovereignty of the Fâtimites; and Egypt, which for the previous 200 years had been under Shi'a administration, became once more, and remained, Suni.

The second change which overtook the 'Abbâsid Khalifate was the gradual loss by its holders of real control over their Empire. More and more the 'Abbâsids degenerated into

1 The title of Khalif was not formally assumed by the Spanish Omayyads until 929, in the reign of 'Abd er-Rahman III. 
rois faineants, while the power passed into the hands of "Mayors of the Palace" and of the Governors of provinces, who, for the most part men of Turkish race, became to all intents and purposes independent Emirs. Ere long the Khalif's prerogatives in the more distant portions of his Empire were confined to being prayed for in the khutbe in the mosques on Fridays, and to the appearance of his name on the coins; at the beginning of the thirteenth century he was a little more than the nominal head of Suni Moslems, and barely retained jurisdiction over his own capital. What remained of his political powers finally disappeared with the fall of Baghdad in 1258 ; but the spiritual function of the Khalifate survived. A scion of the 'Abbâsids, one Abu'l Qasim Ahmed, who was accepted as a son of Zahir, the thirty-fifth 'Abbâsid Khalif, evaded the vigilance of Hulagu's Mongol hordes, and sought refuge with Sultan Baibars in Egypt. The Mameluke or Slave Sultans had but recently wrested Egypt from the Eyubid dynasty founded by Saladin, and Baibars made masterly use of the opportunity afforded by the presence of an 'Abbâsid to acquire moral authority for 
his upstart power. $\mathrm{He}$ installed Abu'l Qasim as Khalif in Cairo under the title of Mostansir billah, and Mostansir promptly conferred upon Baibars the title of Sultan, even going so far as to address to him a homily explaining his duties-truly a delightful touch. The document, it may be mentioned, has been preserved in the life of Baibars. Soon afterwards Mostansir was killed in an unsuccessful attempt to reconquer Baghdad; but Baibars maintained his policy of preserving the Khalifate in Cairo, that it might give legitimacy to his own power. So would Napoleon I. fain have led the Papacy to France. Another 'Abbâsid was discovered by Baibars and was proclaimed Khalif under the name of Hâkim bi-amri'llah; although no further attempts were made to re-establish the Khalifate in Baghdad. The Mamelukes laid down the principle that the Khalif should not leave Cairo except when accompanying the Sultan on an expedition; and thus, as long as Egypt remained independent, the descendants of Hâkim enjoyed their dignity-a Moslem Papacy bereft of its Temporal Power, maintained by and under the protection of Moslem kings. 
For one brief moment, indeed, did one of these nominal Khalifs enjoy the taste of authority. On the deposition of the Mameluke Sultan Faraj, for the second time, in I4I2, the two Emirs principally responsible for his removal agreed to obviate causes of jealousy between them by installing as Sultan a third person. Requiring a nonentity, they selected the Khalif Musta'in, the Emirs reserving to themselves separate spheres of influence. The spiritual and political powers of Islam, at all events as regards Egypt, were thus united once again, and quite fortuitously, in the hands of an 'Abbâsid; but Musta'in "did not apparently much believe in his good fortune; and before investiture as Sultan stipulated that, if he were forced to abdicate, he might resume his nominal dignity of Caliph. This stipulation turned out to be very necessary, although it was not observed; at the end of less than six months the Emir to whom Egypt had fallen, Shaikh Mahmudi, desired the title as well as the rights of Sultan, and easily obtained a declaration from the ecclesiastical authorities that a man of business was wanted at the head of affairs. The 'Abbâsid was therefore deposed 
from his Sultanate, and soon after was deprived of the title of Caliph also." 1

For a little more than a century after this episode the 'Abbâsid Khalifate survived in name; but with the conquest of Egypt by the Ottoman Sultan Selim I. in I 5 I 7 came its end. Selim not only annexed Egypt to the Turkish dominions, but compelled the powerless 'Abbâsid Motawakkil to cede to him the dignity of Khalif and the holy insignia of office. Motawakkil, incapable of resistance, made the required cession, on the validity of which the Turkish claim in large measure depends, and died in Cairo, a pensioner of the Turkish Government, in $153^{8}$. With him the famous 'Abbâsid family disappears from history, and, but for the following exception, is not heard of again. In the fourteenth century one Mohammed, a great-grandson of the 'Abbâsid Mostansir, the penultimate Khalif of Baghdad, migrated to India, where the Sultan of Delhi received him with honour, naming him Makhdumzade, "the Master's Son," and granting him the status and allowance of a prince. Ibn

1 D. S. Margoliouth, Cairo, Jerusalem, and Damascus, London, 1907. 
Batuta, the great Moorish traveller, saw him in about I340, in the course of his sojourn in India, and remarked upon his avarice. This trait must have been unusually pronounced, for Ibn Batuta relates that on his return to Baghdad he found there a son of this Mohammed, living in penury on a daily wage of one dirhem, which he earned as Imâm of a mosque. Mohammed, and perhaps his son, subsequently emigrated to Sumatra, where the graves of their descendants were discovered not long ago.

The soundness of the title whereby the House of 'Osman became possessed of the Khalifate will be discussed later; I would now refer briefly to the development of the Shi'a branch of Islam. The mainspring of the Shi'a faith is Iran; outside the Persian borders it is only professed in parts of the Yemen and the Caucasus, by some twenty millions out of the seventy millions of Indian Moslems, and by certain small and detached communities living as enclaves in Suni lands. Shi'ism is based upon the glorification of the name and family of 'Alî, and found its natural home in Persia through the marriage of 'Ali's son Husein to Shahbanu, daughter of Yazdagird III., last of 
the Sasanid kings of Persia. "In the descendants of Shahbanu and Husayn the Persians saw the heirs of their ancient kings and the inheritors of their national traditions, and in this patriotic feeling may be found the explanation of the intense devotion of the Persians to the 'Alid faction, and the first beginnings of Shi'ism as a separate sect." 1

With the exception of the Fâtimites, who were heretics, the Shi'as have had no Khalif. They ignore the three predecessors of 'Alî, they execrate his successors, as the usurpers of his rights. Their Pontiff is designated Imâm ; and the first Imâm was 'Alî. And while they are by no means united (for the Shi'as have split into many sects), they are divided among themselves principally on the question as to which particular branch of 'Alî's descendants has inherited the dignity of the Imâm. Their main body, the Imâmîyeh, whom we may regard as the exponents of Shi'a orthodoxy, believe in a succession of twelve Imâms, namely 'Alî, Hasan, Husein, and Husein's direct descendants from father to son, ending with Mohammed Abu'l Qasim. The latter is called the Imâm Al-

1 T. W. Arnold, The Preaching of Islam, 2nd ed., London, 1913. 
Mahdi, and is believed not to have died, but to be withdrawn from the world. He will reappear in the last days to reign over the universe for seven years with equity and justice, assuming the title of Mahdi, or "Director."

Many Mahdis have appeared in the course of time, to meet with varying measures of success, although not with the official recognition of the Imâmîyeh body. The best known to Englishmen, and one of the most successful, was the Mahdi Mohammed Ahmed of Dongola, under whose tyranny and that of his successor, the Khalif 'Abdu'llah, the Sudan was for so long the scene of bloodshed and desolation. Among others may be mentioned the Fâtimite 'Obaidallah, already alluded to, and Mirza 'Alî Mohammed, the Bâb, who was executed in Tabriz in I 850 . The Bâb's importance lies not so much in the Bâbi movement, of which he was the founder, for of Bâbis properly so called there are no more, and of their direct descendants, the Ezelis, or followers of Subh-i-Ezel, practically none. But from Bâbism has developed the more extended movement known as Baha'ism, whose name is derived from the Bâb's pupil Baha'u'llah. Baha'u'llah claimed 
that the Bâb's mission was but to herald his, Baha'u'llah's, advent ; and established the headquarters of the new movement at Acre in Syria. He died there in I892, and was succeeded by his son 'Abbas, now known as 'Abdu'l Baha.

The Shi'a heresies do not recognize all of the twelve Imâms; their most important sect, that of the Isma'ilityeh, breaks away from the Orthodox after the death of the sixth Imâm, Ja'far as-Sadiq. Ja'far had disinherited his eldest son Isma'il, the ancestor of the Fâtimites, in favour of the next son, Musa, for being seen in a state of drunkenness; and while the Imâmîyeh accepted Musa as seventh Imâm, a number of mystics, dissidents and others, adhered to Isma'il, arguing that his intoxication showed that he attached greater weight to the hidden precepts of Islam than to the observance of its outward formalities! Nowadays the Isma'ilîyeh are not a very appreciable section of the Shi'a world, although their hereditary chief, the Agha Khan, lineal descendant of the Imâm Isma'il, is a gentleman well known in connexion with Islam in India. It may be not without interest to recall the fact that a branch of the Isma'ilîyeh are the Assassins; but of these once dreaded 
fanatics there have only survived a harmless remnant in the mountains of northern Syria, and the word which has perpetuated in half the languages of Europe the sinister associations of their name.

The Shi'as were unaffected, owing to the fact that the Khalifate is to them a foreign institution, by its assumption on the part of the Sultans of Turkey. The importance of the Turkish Khalifate lies in the extent to which it is accepted among Sunis. The generally recognized qualifications for the Khalifate are: election by the Assembly of the Faithful; descent from Mohammed's tribe of the Qoreish ; and possession of the Sacred Relics, which consist of the Prophet's mantle (Khirqa-iSherif), some hairs of his beard and two of his teeth, a piece of stone bearing the impress of a foot said to be his, his holy standard (Sanjaq-iSherif), and the turban of Khalif 'Omar.' Further, the Khalif is expected to be the principal ruler of Islam, an amendment of the theory that he was to be its only one. How far can the Khalif in Constantinople conform to

1 An interesting description of the sacred relics is to be found in the Tableau Genéral de I Empire Othoman, by the Chevalier d'Ohsson, Paris, I 787, etc., vol. i., pp. 26I-269. 
these requirements? As regards election, he conforms technically, for the Sultan, on his accession, goes through the form of election as Commander of the Faithful at the hands of the 'ulema. The sacred relics are in his keeping, having been surrendered by Motawakkil, the last 'Abbâsid. He is unquestionably the greatest prince in Islam, and de facto ruler of the holy cities of Jerusalem, Medina, and Mecca. He possesses, in fact, more of the externals of the Khalifate than did the majority of the 'Abbâsids, his predecessors ; and he is thereby enabled to ignore what no theological ingenuity can disguise, namely, that he is not an Arab of the tribe of the Qoreish.

This is the only flaw in his claim which has been of practical importance, for it has cost him the recognition of the Moors. Towards the end of the sixteenth century Ahmed IV., Emir of Morocco (I578-I603), taking advantage of the disappearance of the Omayyad Khalif from Spain and of the 'Abbâsid from Egypt, proclaimed himself as Khalif; and since then the Moors have regarded their ruler as Khalif, on the twofold ground that he is descended from Fâtima and is heir to the Spanish Khalifate of 
the West. The Moors are joined in their nonrecognition by various Arab tribes of North Africa and Arabia, and by certain religious Orders, of whom the most important, in this connexion, is that of the Wahhâbis. The Founder of the Wahhâbi movement was one Mohammed ben 'Abdu'l Wahhâb, born in Nejd at the beginning of the eighteenth century. His aims were similar to those of the Reformers in Europe in the sixteenth century; he was, in the literal sense of the word, a Protestant, who desired to purify the lives of Moslems of laxity and vice, and to strip from their beliefs the numerous accretions to the original teaching of Mohammed. But he was a reformer of the austerest school, a John Knox rather than a Luther; he waged war, not only against dishonesty and superstition, but against music, smoking, and all amusements not expressly sanctioned in the Qoran and the Suna. He insisted on the most scrupulous performance of the religious duties enjoined by Mohammed, but was equally stern in condemning as pagan practices of later origin. Among these he included the mystical devotions of the Sufis, the veneration bestowed upon the relics and 
tomb of Sheikhs, and, in particular, the adoration of the black stone in the Kia'ba of Mecca. The venality of judges and the corruption of the mutevelis (trustees) of Evqaf (Moslem pious foundations) were sternly denounced. His teaching soon found such support among the Beduin that he was able to establish a Wahhâbi State, which extended from Arabia into Syria. In 1806 Mecca and Medina fell into the hands of the Wahhâbis, and the pilgrim "was now compelled to take his religious duties seriously; the amusements which formerly had been provided at the season of pilgrimage, and are now provided once more, were forbidden, with the result that the stream of pilgrims declined appreciably." 1 At this stage the Turkish Government intervened; and in I 8 I 2 and I 8 I 3 the Wahhâbis were driven respectively from Medina and Mecca. As a political power the Wahhâbis are now confined to central Arabia, but their religious influence is considerable, and is felt in Africa, India, and even in the Malay Archipelago. That influence is hostile to the Turkish Khalifate.

1 Roloff, "Die türkischen Sultane als Kalifen," in Nord und Süd, vol. 144 . 
Although the practical influence of the Turkish Khalifate, both within and without the confines of the Ottoman Empire, is a thing vague, elusive, variable, and difficult to define, its exploitation by 'Abdu'l Hamid has undoubtedly been attended by success. Not only as regards its Christian population is Turkey a land of mixed races ; it contains many thousands of Arabs, Syrians, Kurds, Circassians, and other non-Ottoman Moslems. Of the two bonds uniting these widely divergent peoples, those of a common ruler and a common religion, neither, singly, has shown consistently the strength adequate to the needs of Turkish policy. When, however, the religious and the political bonds are welded together in the Khalifate, they at once assume an importance which they lack in separation. For his influence with foreign Moslems the Khalif's greatest asset is his possession of Mecca, where all Moslem peoples forgather. In Egypt the influence of the Khalif, who is nominally the political suzerain, is appreciable; in India, Afghanistan, and the central Asian Khanates it is potential rather than ascertained; in China it is probably non-existent. Chinese Moslems obtrude as 
little as possible the foreign origin of their religion; Chinese mosques have hitherto been compelled by law to bear a tablet to the Emperor of China. "Similarly all Muhammadan mandarins and other officials . . perform the rites prescribed to their official position, in the temples of Confucius on festival days; in fact, every precaution is taken by the Muslims to prevent their faith from appearing to be in opposition to the State religion." 1 But an interesting incident which took place in I9I3 proves that the influence of the Khalifate is not unfelt in the Far East. A deputation of Mohammedans from the Philippine Islands, conducted by an American official, visited Constantinople with the object of requesting of the Khalif the nomination of a Sheikh for the instruction of Philippine Moslems. It is needless to say that the deputation was honourably received, and its wish readily fulfilled.

As regards tropical Africa, where annually large numbers of men turn from Deism and paganism to the acceptance of Islam, two tendencies are at work. In regions where conversions are due to the efforts of Sanusi 


\section{THE TURKISH KHALIFATE Iv}

missionaries, who combat the Turkish Khalifate, no accession of authority to the Khalif is possible. This is not the case, however, in districts affected by orthodox Suni propaganda. I recollect that in the course of my service in West Africa an application was made from there to Constantinople for information on a point affecting the education of Moslem boys $;^{1}$ but it must be remembered that many natives of tropical Africa who embrace Islam know little more of their new religion and its practices than that they involve total abstinence from liquor. My own servant in West Africa, member of a tribe which has recently come under the influence of Islam, once expressed to me his views on religion in the following terms : "Christ died for the white man, Mohammed died for the black man." Until Islam is more profoundly understood by its central African converts, the effect of their conversion upon the Khalifate will be slight.

$1 C f$. H. C. Lukach, A Bibliography of Sierra Leone, with an Intro. ductory Essay on the Origin, Character, and Peoples of the Colony, Clarendon Press, Oxford, 1910, p. 22. 
THE LAST DAYS OF A GRAND VIZIER 



\section{V \\ THE LAST DAYS OF A GRAND VIZIER}

ON the I4th of November, I9I3, there died in his native isle the greatest man whom Cyprus has produced since Zeno of Citium, the founder of the Stoic School of Philosophy. This was Mehmed Kiamil Pasha, a man whom age and vast experience had rendered almost a legendary figure in the Near East, a Nestor who, after forty-three years of continuous administrative and political service, was wont, throughout the ensuing twenty-two years of his life, to be recalled from well-earned retirement whenever his country found itself in difficulties which only he was prepared to face.

The precise date of Kiamil's birth is uncertain. One obituary notice in the English press gave it as 1826 , the year of the extinction 
of the Janissaries by Sultan Mahmud II. ; and, despite the mental and physical alertness which Kiamil preserved to the very end, there was in his eyes a look of unutterable age which lent that theory support. The Qibris, the leading Turkish newspaper in Cyprus, gave the date as A.H. I 248 , that is, A.D. I $83 \mathrm{I}$; but the old Turkish registers of births and deaths in Cyprus are very incomplete, and can give the statement no corroboration. The only information they afford on the subject is in connexion with the census of the island made by the Ottoman Government some time between I86I and I878, wherein Kiamil Pasha's mother, Penbé 'Abdu'llah, is stated to be living in the Mahmud Pasha quarter of Nicosia, and to have been born in A.H. I 213 (c. A.D. I 797). His father, one Salih Agha of Pyroi near Larnaca, was, we know, at the time of Kiamil's birth a Captain of Artillery, and was evidently a man free from prejudice since he sent his son to be educated at the Greek school in Nicosia. From Cyprus young Kiamil passed to Cairo, obtained a position in the household of the Pasha of Egypt, and, in the course of a European tour on which he accompanied one 
of the Pasha's sons, visited London during the Great Exhibition of $185 \mathrm{I}$. Kiamil's sojourn in England confirmed his ripening admiration for this country and for its genius: thenceforth, having full command of English, he followed the English press assiduously to the end of his life; thenceforth, to the end of his career, he sought zealously the friendship of England for his country. He cherished deep affection for the British Royal Family, especially for King Edward, to whom he was warmly attached.

Egypt did not arrest Kiamil for many years. In I 860 he exchanged the service of 'Abbas I. for that of the Ottoman Government; and for the ensuing nineteen years, that is to say, until he first entered the Turkish Cabinet, filled an astonishing number of administrative appointments in every part of the Empire. He held such diverse posts as Qaimaqam, Auditor, Director of Evqaf, Mutesarrif, and Vali; he governed, or helped to govern, several provinces, such as Eastern Rumelia, Herzegovina, Kossovo, and his native Cyprus, whose administration has now passed out of Turkish hands. Yet he was not personally ambitious, although he rose rapidly. To an acquaintance 
of mine, who met him when he was Mutesarrif of Chios in 1875 and expressed astonishment that a man of his talents should be content with so unimportant a post, he replied that he found Chios a healthy and an attractive place to live in, and that he was satisfied to remain where he was. $\mathrm{He}$ was above all things a patriot, the most ready of his fellow-countrymen to accept responsibility and to undertake thankless tasks; nor had he long to wait for these. From 1885 , when for the first time he became Grand Vizier (in succession to Küchük Said, who survived him by less than four months), until the tragic coup d'etat of the 23 rd of January, r9r 3 , Kiamil's career is almost contemporary history ; it is, at all events, too well known to need recapitulation here. I will pass by this period and resume my account from the Ist of May, I9I3, when, after a sojourn of three months in Egypt, he returned to his beloved Cyprus for relief from the cares of State, saddened by his inability to avert from his country the dangers which encompassed her.

It was now generally supposed that the exGrand Vizier would travel no more; but after 
a stay of three weeks in Nicosia he surprised every one by leaving Cyprus for Constantinople. His opponents were then in power, and his unexpected return to the capital was the cause of some apprehension to his friends. It is possible that he intended to go no further than Smyrna, where some of his properties were situated, and that, owing to an outbreak of cholera at that port, the steamer was compelled to proceed to Constantinople without calling there. At all events, his presence in the capital was unwelcome to the Government, and two days after his arrival he was once more on his way to Cyprus.

The date of his final return to the island coincided with that of the assassination of Mahmud Shevket Pasha, his successor in the Grand Vizierate. Shevket was shot on the I I th of June; Kiamil landed at Famagusta on the following day. Shevket's death was regarded by many as a retribution for the murder. of Nazim Pasha in January; but the indignation it evoked among his followers reacted on those who were not in sympathy with the Committee of Union and Progress. It led to a considerable exodus from the capital, and among the émigrés were the members of Kiamil Pasha's 
family, who in due course joined the old man in Nicosia. Kiamil Pasha was my neighbour, and occupied, on the Venetian ramparts which encompass Nicosia, a roomy old Turkish house of the seventeenth or eighteenth century, from whose upper windows you obtain wide views over this truly delectable island. From one side you see the fruitful plain of the Mesaoria, bounded on the south by snow-clad Troödos or Olympus, on the north by the serrated ridge of the Kyrenia Mountains; from the other you look over the domes, towers, minarets, and palms of the half Gothic, half Eastern little town to the mediæval castle perched on the precipitous summit of Buffavento, to the five-fingered peak of Pentedactylos, and to the final eminences of the Kyrenia Mountains as they tail away into the Karpass peninsula above Famagusta. Here the old man spent the declining months of his life, surrounded by children and grandchildren (his youngest son is seven, his youngest daughter nine years old), and evoking memories of his distant youth in the home from which he had been absent so long. He took the keenest interest in the development of Cyprus under British rule, and was full of praise for all he saw. 

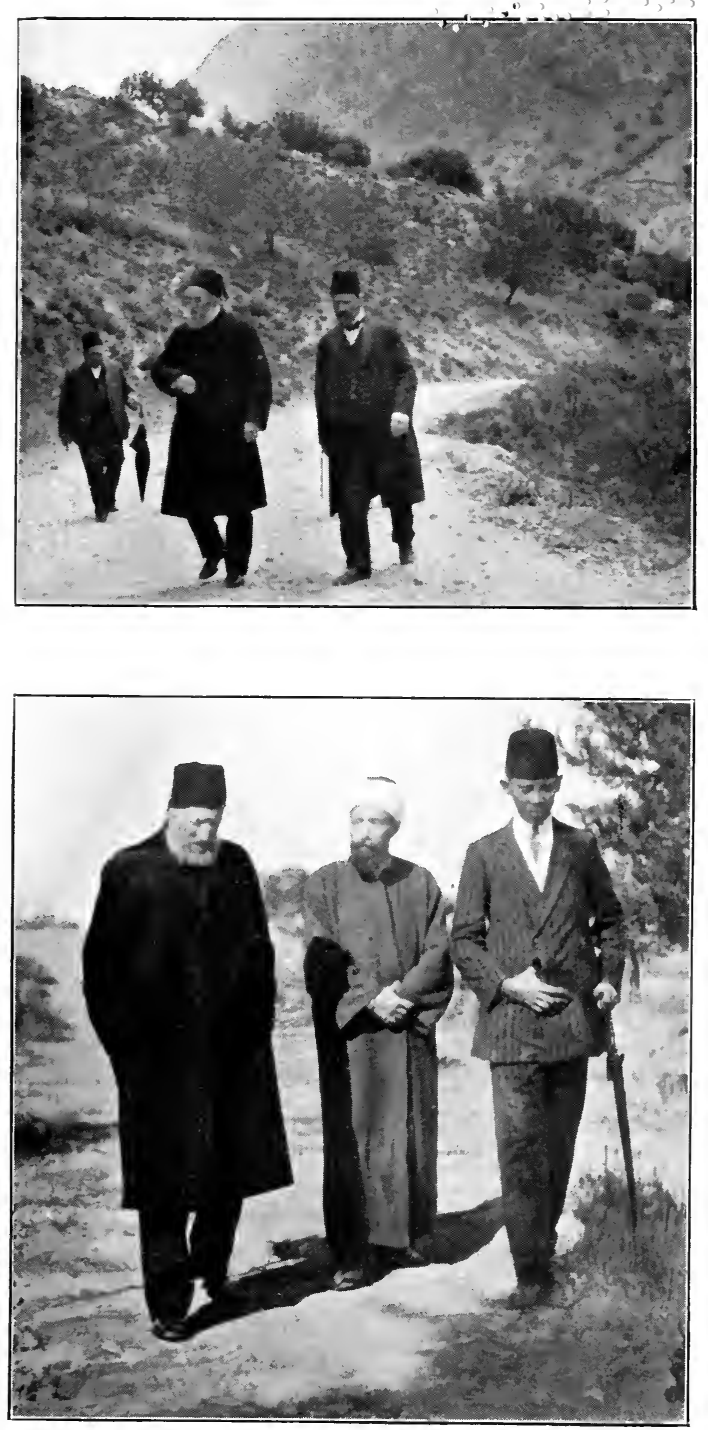

KIAMIL PASHA IN CYPRUS.

To face p. 132. 

He would make expeditions to Larnaca and Kyrenia, would wander alone about the streets of Nicosia and go unattended to the Turkish bath, or would receive visitors in the selamlik of his house, sitting on the divan with his legs tucked beneath him.

For in dress, dignity of manner, and deportment Kiamil Pasha was a Turk of the old school. Unlike those of his compatriots, who have been denationalized by long visits to Paris, he was not ashamed to adhere to his country's customs. To the end of his days he wore the old-fashioned Stambuli frock-coat with upturned collar, and, squatting on the sofa, would clap his hands for his eunuch to bring coffee for the visitors; in the intervals of conversation he took snuff from a little gold snuff-box. He had a way of muttering rapidly in his beard, which made him difficult to follow, whatever language he was speaking; but he knew English and French perfectly, and to the last his intellect was unclouded. Shortly before his death he wrote me a letter in his own hand, in faultless English; eight days before he died, he was dining at Government House with the High Commissioner of Cyprus, and expressed a hope to revisit 
London in the following summer. The end came quite suddenly, at seven o'clock in the morning of the I 4 th of November. He died of syncope, while engaged in his morning correspondence, and was buried that afternoon, in a grave dug, by special permission of the Government, in the court of the Arab Ahmed Pasha Mosque, near to his house.

Truly Turkish, in its contrasts and vicissitudes, had been Kiamil Pasha's career and life; and truly Turkish was his burial. After a service in the stately Gothic Mosque of S. Sophia, formerly the cathedral of the Lusignan Kings of Cyprus, the coffin was borne through tortuous streets and beneath overhanging lattices to its last resting-place, followed by the highest and lowest in the island. Crowding upon the High Commissioner, the principal British officials, and the Moslem dignitaries, the rabble of the town struggled and pushed, instigated partly by curiosity, partly by the hope of being able, for a moment or so, to take part in the bearing of the coffin. And as the procession approached the Arab Ahmed Mosque with its swaying burden, a flower-seller, dressed in the baggy white breeches of the 
Turkish peasant of Cyprus, and with bare legs and slippers, joined the throng, laid aside the tray of violets he had brought into the bazaar for sale, and put his shoulder under the coffin. It was the Grand Vizier's nephew, his sister's son, who grows flowers and vegetables in the neighbouring village of Devtera, and had come into the town that afternoon to ply his trade. He encountered the procession accidentally, unaware of his uncle's death, but when he learned who was being carried to burial, he took his place as a matter of course, and no one thought his participation strange. For if Turkey is-or was-an autocracy, it is in some respects the most striking of democracies. It can give rank, honour, and position to a man, but not to his descendants; a poor Turk or one of humble birth becomes Vizier or Mushir as easily as a Stambuli Effendi. The Turk need not be less a gentleman because he wears peasants' clothes, nor a parvenu because he has reached eminence by a long ladder. 

VI

AT AN OPENING OF

THE LEGISLATURE OF CYPRUS 



\section{VI}

\section{AT AN OPENING OF \\ THE LEGISLATURE OF CYPRUS}

Probably at no other official function in the world which is held under British auspices are there gathered together so many picturesque and diverse elements as at the opening of the annual Session of the Legislative Council of Cyprus. The Council Chamber in Nicosia is by no means palatial ; it is, in fact, of Spartan simplicity as regards its appointments; but on these occasions it enshrines a medley of ceremonial dress so remarkable and so interesting that its lack of splendour passes unnoticed.

The members of this Council, now summoned to hear the opening speech of the High Commissioner of the island, are composed of three different sections. There are in all eighteen members, part of whom are elected, part non- 
I40 THE CYPRUS LEGISLATURE vI

elected; and the latter consist of six British officials, who sit either ex officio or by nomination. Of the elected members three are Turks, chosen by their compatriots to represent the Turkish element in Cyprus, and nine are GreekChristians, chosen by the Greek-Christian community. A horseshoe table, covered with green baize, occupies the body of the room; and the official members, who are seated in the middle, divide the Turks on the right wing from the Greek-Christians on the left. Raised a step above the floor is the chair of the President of the Council, the High Commissioner of Cyprus, resplendent on such an occasion as this in orders and gold. $\mathrm{He}$ is flanked on either side by the official members, who are arrayed in the blue British civil uniform, or, in the case of the King's Advocate, the legal adviser of the Government, in the robes of a King's counsel.

The Turkish members, departing from this uniformity, present considerable variety of dress. One of them most probably holds some official rank in the Ottoman Empire, a purely honorary distinction entailing no obligations, and in this event wears the Turkish civil uniform of black and gold, the quantity of gold 
varying according to the ranks, fifteen in all, I believe, into which the Turkish hierarchy of civil officials is divided. Another may belong to the Khoja class, that is to say, to the semiecclesiastical category of those who have studied the Sacred Law and furnish Turkey with her Qadis, her Imâms, and her schoolmasters, and wears, consequently, a black gown which descends to the ankles and a white turban bound around his fez. Another, belonging to neither class, wears European evening dress and a fez. The Greek-Christian members are all in evening dress, a contrast to the mass of colour around them.

The dignitaries who in virtue of their positions are invited to be present at the opening of Council contribute even more than the members to the picturesqueness of the scene. Along the walls of the Council Chamber chairs are ranged for the visitors, and nowhere but in Cyprus can be seen such interesting and piquant juxtapositions. There are the English Judges of the Supreme Court, in scarlet and full-bottomed wigs; there are their Eminences the Qadi and the Mufti of Cyprus, in the splendid dress worn by high officials of the 
Mohammedan Sher'i or ecclesiastical Courts. These Courts, in Turkey, exercise jurisdiction over Mohammedans only; but the jurisdiction is a wide one, and may be likened to that of the English ecclesiastical Courts prior to the Reformation. There are nine ranks of Sher'i Court officials, ranging from the humble Muderis to the Sheikh-ul-Islam; and their gala dress increases in magnificence as they ascend the hierarchical ladder. As they are all of the Khoja class, their uniforms consist of variations on the gown and turban worn by the ordinary Khoja. On full-dress occasions the gowns of the lower ranks are blue, those of the higher ranks violet; and in the highest ranks, to which the Qadi of Cyprus belongs, the violet gown is heavily gold-embroidered. And over the white turban which binds the fez is laid a band of gold brocade, of varying width according to rank, with a tail of white linen, gold-tipped, hanging down the back.

Next to their Eminences are placed his Beatitude the Archbishop of the Autocephalous Church of Cyprus and his Metropolitans, swathed in voluminous folds of black in which can occasionally be discerned, as they move, 
their pectoral crosses of brilliants and other precious stones. With them, too, sits his All-Saintliness the Abbot of Kykkos, head of the greatest and wealthiest of the eightytwo monasteries of Cyprus. Then comes the Suffragan Bishop of the Maronites, in whose costume the two-fold aspect of his church, one of the Eastern Uniat Churches, is manifested. His cassock and stockings of pavonazzo silk proclaim the prelate of a church in communion with Rome; his black headgear, resembling a "pork-pie" cap, shows that the Maronite Church retains something of her local Syrian usages. The Father Superior of the Franciscans and the Armenian Vicar-General represent two other religious bodies which have flocks in Cyprus.

The other side of the room is occupied by senior officials of the Government and their ladies, and by other distinguished visitors. Certain officials of the Cyprus Government who are Turks by race also enjoy civil rank in the Ottoman Empire, and are to be seen clasping heavy curved swords, while their bosoms are decked with gold lace and adorned with the Orders of the Mejidieh and 'Osmanieh. 
Sitting cheek by jowl are the chaplain of the Church of England, in academic gown and hood, and the hereditary Sheikh of the Mevlevi Dancing Dervishes, in the stately garb and the tall bonnet of camel hair, encircled by a green turban, which he affects on solemn occasions. The scene provides a strange contrast of race and religion, illustrates a singular variety of civilizations; and the Turkish and Greek Translators to the Council remind one, if reminder be needed, of the linguistic problems which the administration of Cyprus involves.

The High Commissioner concludes the reading of his speech, removes his hat as he bows to the Council, and leaves the Chamber to inspect the guard of honour furnished by the Cyprus Military Police, a force composed of Turks and Greek-Christians. Meanwhile copies of the speech, printed in the three official languages of the island, are distributed among the members; and the Zaptieh band plays "God save the King" in the hearing of an audience which for picturesque variety it would be difficult to match outside the Levant. 


\section{VII}

\section{S. ANDREW THE MIRACLE- WORKER}





\section{VII}

\section{S. ANDREW THE MIRACLE- WORKER ${ }^{1}$}

IT is said generally, and to some extent truly, of the Holy Orthodox Eastern Church that the spirit which once animated her has long since fled, leaving behind it little else than a shell of lifeless formalism. The subtle controversies and hair-splittings of her Councils, the fierce disputes over minutiæ of dogma and ritual, whereof her history is in such large measure composed, do something to justify the criticism; but they who only consider this aspect of the Church gravely underrate the significance at the present day of her hold upon her flock. Their religion, mechanical as it may appear to the outsider, is to the Christian peoples of the Levant a very living force in

1 Written in collaboration with Mrs. A. K. Bovill. 
more than one respect; it is particularly so in the intimate-nay, personal-relationship which binds them to their Saints, and to the Panagia (All-Holy) Theotokos (Mother of God).

A wanderer in the Levant cannot fail to realize at the very outset of his journey the ubiquity of Orthodox Saints. Let him travel by a Greek or Russian ship : he is immediately confronted in the saloon with an icon of Saint Nicolas. Let him land and walk on shore and rest by a spring of water: in all likelihood he will discover it to be an ayasma (áría $\mu a$, holy and beneficial spring) sacred to Saint George. Orthodox Saints and the many localized manifestations of the Panagia are often the immediate successors of pagan gods, as familiars and patrons of some grove, or valley, or stream, differing from their predecessors only in name; sometimes they inherit their specific attributes, as in the case of the aforementioned Saint Nicolas, who follows Poseidon in the guardianship of seafaring folk. But it is principally as healers of disease and of sorrows, as menders of broken hearts, as performers of what, for want of a better term, we must call miracles- 
in short, as the alleviators of all ills, physical and mental, which humanity is heir to-that they are venerated; it is to the successes, fraudulent, fortuitous, or genuine, with which they are credited, that they owe the extent of the cult of which they are the objects. Many so-called miracles are no doubt due to coincidence or credulity or suggestion, or to a combination of all three; but it is beyond dispute that a certain proportion of suppliants see the realization of their hopes. Did they not, the Saints would have been discredited long since. Neither the Panagia of Tenos nor She of Lesbos would continue to attract annually their thousands of pilgrims; the little country churches and chapels thickly dotted over the lands of the Levant would cease to be visited by ever-faithful devotees at the time of their fair, or panegyris. Manifestly, a single miracle creates more stir than a hundred failures; it is equally manifest that year after year the faith of the disappointed finds confirmation. Of one of such miracles, one which occurred in I9I 2 and aroused deep interest throughout the island of Cyprus, we here propose to tell.

The circumstances were as follows. In 
I895 one Maria Georgiou, a Greek peasant woman and a widow, living in the small seaport of Alaia ${ }^{1}$ on the borders of the vilayets of Adana and Konia, Asia Minor, lost her son Panteli, a lad of thirteen. The boy had gone to a neighbouring village to visit an old friend of the family, the papas who had baptized him, and was not seen again. His mother, after waiting in vain for his return, set out for the village, in the hope of finding him there. But neither the priest nor any one else had seen Panteli, all trace of whom had completely vanished. Inquiries were set afoot, but without result; and the only way in which the boy's mysterious disappearance could be explained was by the supposition that one of the roving bands of brigands which infested the neighbourhood had kidnapped him as he was walking along the road. Years passed, and the sorrowing mother abandoned all hope of finding her child.

Seventeen years later, in the early part of I9 2, Maria declared one morning that in the night she had seen a vision of Saint Andrew. The Apostle, so she affirmed, had appeared to

1 So called from the name of its founder, the Seljuq Sultan Ala'u'd-Dîn I. 
her as she slept, and had communicated to her a clear and precise injunction. He bade her, if she desired to hear news of her long-lost son, make a pilgrimage to his shrine in Cyprus, to the Church of Apostolos Andreas; and she announced her intention of proceeding thither with as little delay as possible.

Now the Church of Apostolos Andreas is the remotest object in all Cyprus, lying at the extreme end of the Karpass peninsula, that long and narrow strip of land which, like an index finger, seems to point at the Syrian coast. A visit to it is even for natives of other parts of Cyprus no mean expedition, entailing many days of weary journeying on donkeys; and it is very noteworthy that this lone old peasant woman, a stranger to the island and unused to travel, should have placed such implicit faith in the vision that she had no hesitation in undertaking what must have appeared to her a most formidable pilgrimage. The Church is not, indeed, without some reputation. Miracles had already been performed at its shrine; and it is possible that reports of these had crossed the Karamanian Strait into Asia Minor, and had served to 
encourage Maria in her venture. Here, at this Land's End, half concealed among the rocks at the water's edge, is a tiny Gothic chapel, dating from the time when the Lusignan dynasty ruled in Cyprus, and enclosing three ayasmata, three sacred springs of water, which are believed to have issued from the spot where S. Andrew first set foot on Cyprian soil. Immediately above and behind it, massive substructures support a modern Greek church, large, bare, and whitewashed, which one Hajji Economou, a priest of the village of Rhizo Karpass near by, built toward the middle of the nineteenth century with the funds that had accrued from the annual pilgrimages to the little chapel below.

For many years before the building of the new church, these pilgrimages had been dwindling in importance. The little chapel was becoming neglected; one rarely heard of a cure effected at its springs. Then, so said old Hajji CEconomou, the Apostle Andrew began to visit him in his dreams, urging him to revive the prestige of the shrine by undertaking the erection of a more imposing sanctuary. The priest accordingly set to work, and in 1867 the 
church was finished, and consecrated by $\mathrm{His}$ Beatitude Sophronios II., the late Archbishop of Cyprus. The completion of the building, whose white campanile is a beacon to mariners and a landmark to the villagers who approach it from the north, was celebrated by a large panegyris, and a new era of the shrine's prosperity was inaugurated. Again suppliants and sufferers were to be seen wending their way thither in long procession, some riding on donkeys, others walking and carrying their heavy top-boots in their hands, as is the habit of the parsimonious villager; again the Apostle exercised his beneficent influence over the holy water, clinching his popularity, by a remarkable demonstration of its healing properties. Thirty miles away, in the Turkish village of Galatia, there lived an old Turk who for a year had been blind in both eyes. A Christian friend urged him to bathe his eyes in the holy spring, and the Turk, albeit a native of the most zealous Moslem community in the island, consented to go there with the Christian, who related the story to the writers. Entering the low and sombre little chapel, in a corner of which, some feet below the level of the floor, are the holy 
wells, the Moslem knelt and anointed his face with the water. For some minutes he remained, unseeing, within the chapel. But on being led forth into the sunlight, he cried out to his astonished companion that he could see. It was even so. His sight had been restored; and he returned to his village filled with gratitude to the Apostle who had shown compassion on a follower of the Prophet.

This and other tales had probably come to Maria's ears before she set out from Alaia on her weary journey. At Adana she took train for Mersina, which is over against Alexandretta, the new port for the Baghdad railway; and at Mersina embarked for Larnaca in Cyprus. It was the week before the Orthodox Easter, and the ship was filled with Cypriotes, labourers on the railway, who were returning

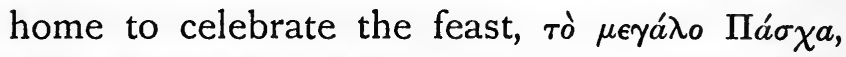
with their families and friends. Among the deck passengers, silent and unobtrusive in the midst of their voluble fellow-travellers, were also two Turkish dervishes, with one of whom Maria fell into conversation. It transpired that they were bound for the same destination, and that the dervish and his companion were 
proceeding to Cyprus on business connected with the property of their tekye or convent. It should, perhaps, be explained that in parts of the interior of Asia Minor the Greek peasants are almost wholly, and in some cases wholly, ignorant of Greek, and employ the Turkish language not only in everyday life, but even for the celebration of the liturgy in their churches. Hence Maria engaged more naturally in conversation with the Turkish-speaking member of a Moslem religious confraternity than with her Cypriote co-religionists. For some time they talked of the events of the voyage and of the unknown island, their objective, until a chance question from her companion moved Maria to tell him of her loss and marvellous vision, the cause of her journey to the distant shrine.

For awhile the dervish listened in silence, but became more and more agitated as she proceeded with her story. Finally, he asked her, almost roughly, if her son had had any distinguishing marks on his body.

"Yes," said Maria; "a mole on his chest and another on his shoulder."

On hearing this the Moslem opened his 
robe and showed the very marks Maria had described, while the woman first gazed dully, then leaned forward and touched them, as if unable to believe the evidence of her eyes. Her companion poured out a flood of explanations, unintelligible to any one but the mother, whose quick instinct was now convinced of the truth which the bearded face and strange dress had previously concealed. With a cry she clasped her son in her arms, as he wildly tore off his high brown bonnet of camel-hair, the head-dress of his Order, and flung it far into the sea.

Though stunned at first by the sudden joy of their reunion, the pair were soon able to talk connectedly. The son told the mother how, as he was going to the priest's village on the fateful day, he had been kidnapped by Turkish brigands, who had eventually disposed of him in Constantinople. There, after passing through various hands, he was instructed in the tenets of Islam, and educated as a dervish. $\mathrm{He}$ was never left alone, and was moved constantly from place to place, so that his childish memories had very nearly become effaced. He had forgotten his native place 
and the name of his parents, yet some strange and instinctive attraction had drawn him to his mother, whose story, with its details of events and places, reforged in a flash the missing links in the chain of memory which still bound him to his early life. When Maria was calm, she turned to the passengers who had gathered around her, and, with the slow tears of age running down her wrinkled face, told them of the miracle which had restored her son after so many years. The Cypriote labourers, many of whom hailed from the Karpass, where the Apostle is regarded as the tutelary deity, raised shouts of rejoicing, and fell on their knees to praise the Saint for the sight which they had been privileged to witness. Willing hands helped the ex-dervish out of his dervish dress, and clothed him in the baggy blue trousers, loose shirt, and embroidered waistcoat worn by the Christian peasantry of Cyprus, the men contending for the honour of providing them from their scanty store. A collection was made for Panteli and his mother, who announced their intention of going together to return thanks at the shrine for their happiness; and thus, surrounded by their newly-made friends, and in 
an atmosphere of religious fervour, the two eagerly awaited their arrival at Larnaca.

Almost as soon as they had landed, news of the miracle spread like wildfire through Larnaca ; and when Panteli had visited a barber for the removal of his beard, he and his mother were taken to the Bishop of Kition (Larnaca), who, after satisfying himself as to the facts of the case, rebaptized the ex-dervish in his former name. And on the following day the pair set out for the Ultima Thule of Cyprus, driving to Famagusta, the eastern port of the island, where they hired the donkeys which were to carry them over the last and most arduous stage of their journey. They passed the scanty remains of ancient Salamis, immortal in memories of five centuries before the landing of S. Paul, and rested that night in a khân by the sea at the picturesque pass of Boghaz. The Orthodox Easter was approaching; and in the early dawn of Good Friday the patient Cypriote donkeys bore them into the Karpass, through green and prosperous country where the shining crops were as yet uncut, and spring flowers made the air fragrant with their sweetness. From time to time they encountered 


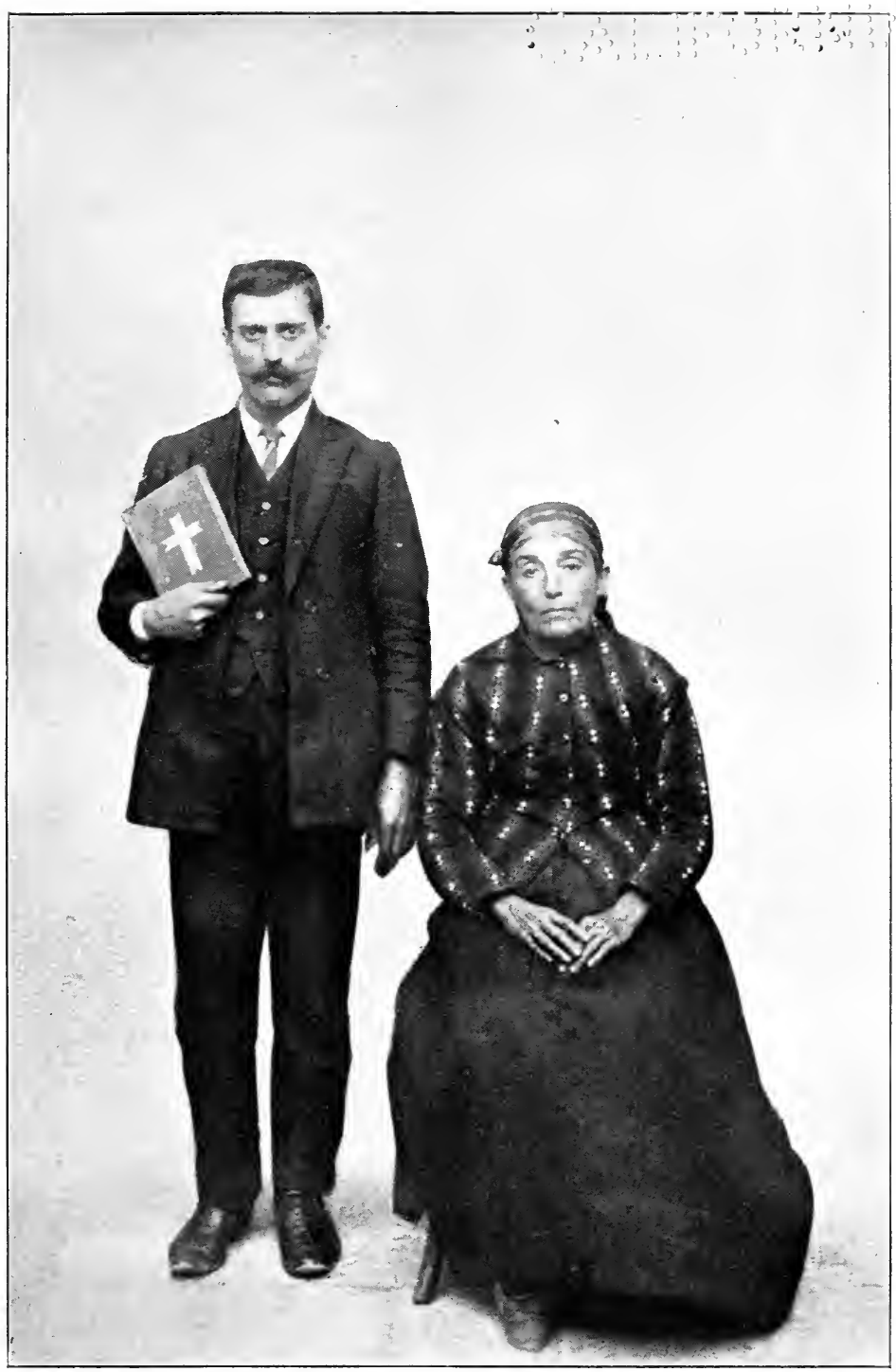

MARIA AND PANTELI.

To face $p . \quad 158$. 


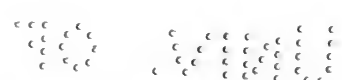

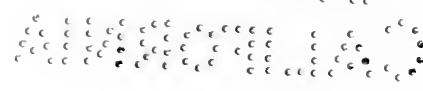


groups of peasants homeward bound for the Holy Feast, and were called upon for their story, whose fame had already preceded them. In return they received the congratulations of the pious Karpasiti, men and women, who all their lives had depended on their well-loved Saint for healing and comfort. Towards evening they neared the crest of a long hill, topped by the red roofs of Leonarissos ; and on arrival at the village were given shelter and a frugal meal of black bread and olives by the kindly village folk. Nothing else was available, for the Lenten fast would not end until Easter Sunday.

Night fell, its stillness broken by the clanging bell of the church, and together they went through the soft darkness to obey its summons to attend the Requiem whereby Eastern Christians commemorate the night of Our Lord's Passion. It was a strange sight to Panteli, and he gazed, somewhat bewildered, about the crowded building. Heavy glass chandeliers, now ablaze with lights, were suspended from the vaulted roof. At the east end the iconostasis, heavily gilt, gleamed fitfully beneath swinging lamps. The central icon of 
a dying Christ gazed mournfully down upon the surging crowd. High up in semi-darkness at the western end of the church was the women's gallery, partly concealed by a grille, behind which the murmur of girlish voices mingled with the querulous cry of babes. By one of the doors was a tray full of yellow wax tapers, and every one, on entering, took one in return for a ro-para piece, the smallest coin of Cyprus. The ex-dervish, holding his lighted taper, looked reverently at the rose-covered bier containing an embroidered figure of the crucified Saviour, while around it a circle of priests in sombre Lenten vestments, rent and greasy with age, intoned a chant weirdly melancholy, a wailing intercession which was taken up by the congregation, who now, with bowed heads, crossed themselves and groaned. At intervals throughout the service a priest removed his high black bonnet, the kalemavkion of the Orthodox Church, and, prostrating himself, embraced the bier and sprinkled rose-water upon it. One by one, his companions did likewise; then, in a wave, the congregation surged forward, Panteli and his mother being swept on with the rest. In pairs or singly the 
villagers advanced to give the kiss of peace, the little children sitting wide-eyed in their mothers' arms. The priests stood aside now, and their shaggy white hair, flowing on to their vestments, framed faces wrinkled with age and exposure in the fields, faces almost Jewish in type, which only Rembrandt could have painted. Two acolytes, one holding a smoking brazier, the other a bottle of rose-water, censed and sprinkled the worshippers, who dried their hands on their heads and faces and turned away to mingle again with the crowd. The church darkened as the tapers burned low. Clouds of incense, "strong, thick, stupefying," hung in the air; the feeling of indescribable solemnity increased. Panteli knelt beside the bier, while those nearest to him murmured prayers of thanksgiving; then, rising, and crossing himself, joined his mother and went out into the night.

Only two days now separated them from the shrine, which lies some fifteen miles, or five Cyprus miles, beyond Rhizo Karpass, the principal village of the peninsula. They rode towards Rhizo Karpass beneath a blue sky flecked with feathery clouds, along paths 
bordered by anemones and cyclamen, and shadowed by silvery olives where flocks of goldfinches flashed from bough to bough. Rhizo Karpass is a garden village whose every house stands within its own parcel of ground; from the plateau on which it is built it throws out a multitude of suburbs, green in spring-time with the glossy foliage of the mulberry. In the house of the Mukhtar, or village headman, they sought and found lodging, and, resting in the arched courtyard, watched a group of women who at a manqal, or brazier, were cooking unleavened bread and biscuits, covered with sesame seeds, destined to accompany the Paschal lamb on the following day. A busy stir of preparation filled the village as the people made ready for the great feast. $U p$ in the belfry of the church a boy was lighting the lamps for the Easter Eve service, and Maria and Panteli were soon wakened from the tired sleep into which they had fallen by the clashing of bells. The night was faintly luminous with the light of a few pale stars, and through the gloaming the dim shapes of those approaching the church were outlined against the bonfire which was burning outside it. Inside, the 
church was brilliantly lighted, and the floor was strewn with fresh branches of myrtle, the emblem of victory. An icon of the bleeding Saviour, crudely and grimly realistic, hung over the table at which, with joke and laughter, the people were buying their tapers; and as they pushed their way forward, a child's laugh rang out merrily, heralding a note of gladness. For the rigid Lent of the Orthodox Church was spent, the waiting and fasting all but accomplished; and in all simplicity the villagers exemplified the words of the Psalmist : "Weeping may endure for a night, but joy cometh in the morning."

The crowd swayed backwards and forwards, opening a passage to enable worshippers to approach the iconostasis; and now a young girl, now a village dandy or palikari, now a blooming matron, ascended the steps and reverently kissed each sacred picture. Little children, even babies in arms, were held up to press their tiny lips to the painted boards-boards incrusted with the dirt of ages, and depicting emaciated and unlovely saints in the unchanging style of Byzantine painters. To these a contrast was afforded when a group of men approached 
slowly, supporting an old woman so bent and decrepit that she looked a living corpse. The rather large features, yellow and inexpressibly wrinkled, protruded from under a white sheet, and the slippers on her tremulous feet clattered beneath the loose Turkish trousers as she was lifted up the steps. Feebly she mouthed the icons, groping her way along; and it was so surely her last Easter that, when she disappeared, there remained behind her the chill shadow of death. A villager, holding two branched candlesticks above his head, emerged from behind the iconostasis, and was followed by a priest bearing an icon of Hagios Synesios, the patron saint of the church. Two acolytes, dressed in ragged cassocks of scarlet, brought up the rear, swinging censers, from which the blue smoke curled slowly to the dome, filling the church with penetrating smell. The little procession reached the end of the church and passed outside, followed by the congregation holding their tapers. It encircled the building, while the priest chanted a hymn, and entered it again by another door, the people struggling at the narrow entrance. Then, with a few prayers, the service was ended, and the con- 
gregation straggled out into the grey light of the dawning Easter.

The pitiful bleat of lambs about to be slaughtered heralded the sunrise, and a confusion of sounds filled the village as the people forsook their homes to throng the streets. These presented a gay aspect. Over the door of every house there now hung the Easter garland of roses and wild flowers; every one was dressed in holiday attire. The old Cypriote dress has survived more completely in the Karpass than elsewhere in the island, and the men vied with the women in picturesqueness. The men wore high boots, baggy trousers of strong, coarse Cypriote cotton, locally dyed with indigo, double-breasted waistcoats fringed and embroidered, and astrachan caps set jauntily on the sides of their heads. The women were resplendent in tightly laced bodices, and in brilliantly coloured skirts, purposely cut short so that the white Turkish trousers should be seen beneath them, while the more fortunate boasted of necklaces of Venetian ducats, relics of the day when The Serene Republic held sway in Cyprus.

Maria and Panteli set out from Rhizo Kar- 
pass before noon; but at the next village, attracted by the sound of music, stopped for a few minutes to watch some men and women dancing before a rustic coffee-shop. Under a little arbour of vine-trees two fair and blue-eyed girls, dressed in scarlet and green; faced one another with downcast looks. Slowly, and as if half asleep, they began to move with shy, sidling steps and mincing movements of hands and arms, as the blind fiddler played a Cyprian melody, one of those plaintive melopées in the Dorian mode, reiterant and monotonous, which seem to have no beginning and no end. Presently two young men sprang up to take the girls' places, rubbed the palms of their hands in the dust, and, throwing their arms above their heads, proceeded to dance with extraordinary lightness and abandon. They slapped their thighs, they punctuated the music with heavy stamps; and the vitality which was lacking in the girls' dance was here most noticeably present. From time to time a man would step out from the audience, and, licking a coin, plaster it on the blind musician's forehead; the musician played on unconcernedly, merely wrinkling his brow to allow the money to drop into his lap. 
Then, in a thin cracked voice, which admirably suited the accompaniment, he droned a native love-song in the Cypriote dialect :

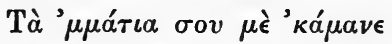

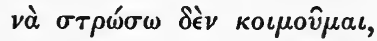

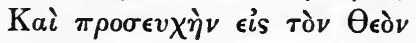

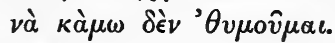

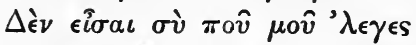

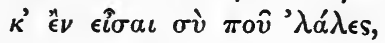

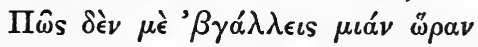

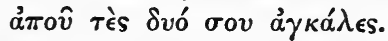

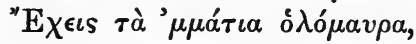

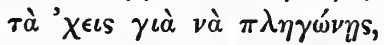

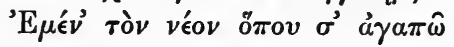
$\gamma \iota \grave{a} v \grave{\alpha} \mu \grave{\epsilon} \theta \alpha \nu a \tau \omega ́ v \eta s$.

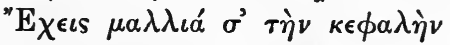
$\psi \iota \lambda \alpha^{\prime}$ ' $\sigma \hat{\alpha} \nu$ тò $\mu \in \tau \alpha \dot{\xi} \xi$,

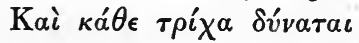

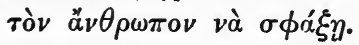

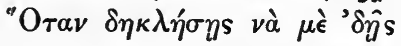

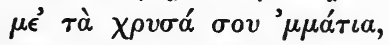

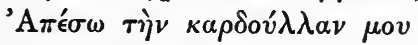

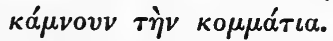

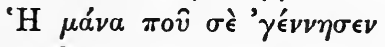

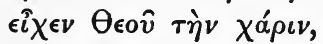

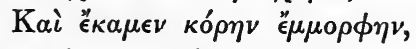

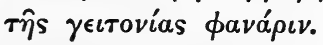

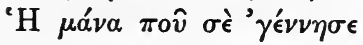

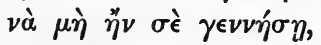

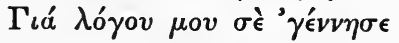

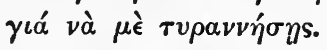

Here is a rough translation of the song: 
For thine eyes' sake kind sleep forsakes my bed;

God is forgotten, and I cannot pray.

Thy broken promise haunts my fevered head:

That, lulled and dreaming, I should rest alway

Clasped in thine arms, while flashing eyes, jet black,

Gazing in mine, turn all my blood to fire.

Have mercy on me, torn as on a rack

By hopeless love and pitiless desire.

Around my throat each silken hair, like cord,

Strangles the life which bubbles out in pain.

And others, too, have felt the piercing sword

Of golden glance, and died for thee, in vain.

O happy mother, she who gave thee birth!

Might it have been that thou in heaven hadst stayed,

Nor come in loveliness and cruel mirth

To be my fond heart's tyrant, fickle maid!

Our travellers now urged their beasts forward, and the word spread that the Christians from Alaia were going. The fiddler rose, still playing his instrument, and, led by the audience, accompanied them to the outskirts of the village. As they passed through the winding street, women ran out of their houses with narrow jars of rosewater and with small earthenware bowls of fragrant burning olive-leaves; the pilgrims waved their hands over the sacrificial smoke, and submitted gratefully to the baptism of rosewater. For many hours they now followed a 
rough track, the sea sounding more clearly in their ears as the promontory narrowed; and towards evening saw the campanile of the monastery as it caught the last gleams of the setting sun. Skirting old Hajji Economou's lonely grave, which lies in a waste place overrun by pigs and chickens, and is unfurnished with any tombstone to tell the dead man's virtues, they entered the ancient chapel and fell on their knees before its rude altar. Here we will leave them, weary but grateful, and happy in the fulfilment of their hearts' desire.

And as to the truth of the story we have told. It is not our purpose, nor does it lie within our power, to explain or account for Maria's vision and its marvellous accomplishment. We are content to assume that it was one of those occurrences of miraculous nature whose prevalence in the Levant we have alluded to at the outset of this narrative. Our concern has been but to relate the concrete facts of this particular instance of such happenings, as they are well known throughout Cyprus ; and of these there is ample corroboration. By law, all works published in the island are registered by Government and their titles set forth in the official 
Cyprus Gazette; and in the issue of that periodical for the I 7 th of January, I9I3, more than half a page of the section devoted to the list of works so published is taken up with the titles of ballads and pamphlets dealing with the miracle of the ex-dervish of Alaia. 


\section{VIII}

OF PRIESTS AND PATRIARCHS 



\section{VIII}

\section{OF PRIESTS AND PATRIARCHS}

OF the factors which govern the life of peoples in the Turkish Empire and its lost provinces, the religious is admittedly one of the most vital. The native inhabitants of European Turkey are not classified by race for administrative purposes ; they are divided into millets or "nations," which rest on a basis religious rather than racial. Moslems, of whatever race they may be, compose the millet of Islam; the Christian subjects of the Porte form separate millets according as they acknowledge the Patriarch of Constantinople, the Pope, the Bulgarian Exarch, the Armenian Katholikos, or the Protestant Vekil, as their ecclesiastical superior. As a result of this system, and of the fact that to each millet a measure of autonomy is given, the churches in Turkey 
are not only spiritual refuges, but the rallyinggrounds of national aspirations; the head of a Church is not only a spiritual chief, he is also a political ethnarch. It is thus immaterial that the ethnologist in the Balkans is not infrequently baffled; his place is taken by the prelates and clergy who influence the results of the religious census. The ubiquity of the Eastern ecclesiastic, and his varied activities, render a study of his habits and foibles both instructive and diverting; it is a field which offers a profitable return to the observer. In the matter of erudition, for example, the greatest contrasts may be observed among the Orthodox clergy. There are monks in Mount Athos who are men of the world, zealous students of the financial press which guides them in the Stock Exchange operations to which they are addicted. On the other hand, I have known Abbots in various parts of the Levant whose signatures consist of the imprint of the abbatial thumb, smeared with ink, the All-Saintly-and-Erudite ones being strangers to the arts of reading and writing. One Abbot in particular, who died about eight years ago, was unable so much as to say his prayers, but 
employed a sort of whipping-boy for the purpose. The Abbot sat in his chair, the boy stood beside him and spouted the prayers, and the Abbot's vicarious devoutness was universally pronounced to be edifying and satisfactory. His brother and successor, the present Abbot, is, however, a man of some culture, having once been a schoolmaster; he makes, moreover, a most excellent liqueur, so that he is in all respects a pillar of the Church. His only peculiarity is a failure to apprehend the functions of a mosquito-net. In winter, when there are no mosquitoes about, the holy man puts down his net and sleeps inside it for warmth; in the hot weather, when the mosquitoes begin to swarm, the net is removed.

If we find simplicity in signatures exemplified in the Abbot's thumb, so do we find the converse in the official signatures of Orthodox Patriarchs. These are indeed fearful and wonderful things, requiring close on half an hour to be completed; and when they are achieved, I defy anybody to decipher their subtle and tortuous sinuosities. What they would become were Patriarchs to subscribe their full titles is indeed difficult to contemplate, 


\section{I76 PRIESTS AND PATRIARCHS}

VIII

for the titles of Patriarchs outrun in length and sonority those of the mightiest of kings. Thus,

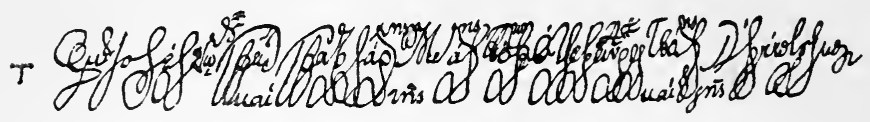

THE SIGNATURE OF THE PATRIARCH OF ALEXANDRIA $?$

His Beatitude of Alexandria is known as "The Most Blessed and Holy Pope and Patriarch of the Great City Alexandria, and of all Egypt, Pentapolis, Libya, and Ethiopia; Father of Fathers, Pastor of Pastors, Archpriest of Archpriests, Thirteenth Apostle and Ecumenical Judge"; he of Antioch as "The Most Blessed and Holy Patriarch of the Divine City Antioch, Syria, Arabia, Cilicia, Iberia, Mesopotamia, and All the East, Father of Fathers and Pastor of Pastors"; while the Coptic Patriarch rejoices in the designation of "The Patriarch of Egypt, Jerusalem, the Holy City, Nubia, Abyssinia, the Five Western Cities and all the preaching of S. Mark." The Ecumenical Patriarch goes one better. $\mathrm{He}$ is the only Eastern prelate entitled to be called "The Most Entirely

1 The interpretation of this hierogram is as follows: " $+\Phi \dot{\omega} \tau$ cos

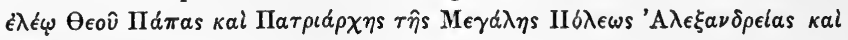

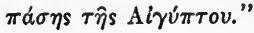


Holy"; but this has not prevented the holders of that office from suffering, in the course of history, from a distressing absence of security of tenure. In a recently published catalogue of the Patriarchs of Constantinople ${ }^{1}$ we find the following remarkable statistics. Of 328 vacancies between A.D. 36 and 1884

I 40 were by deposition, 4 I by resignation,

3 Patriarchs were poisoned,

\begin{tabular}{|c|c|c|c|}
\hline & atriarch & " & \\
\hline & 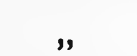 & , & blinded, \\
\hline & , & $"$ & drowned, \\
\hline & $"$ & ", & 1 \\
\hline & , & $"$ & strangle \\
\hline
\end{tabular}

so that only 137 closed their term of office by a natural death. Under the circumstances it is surprising to read that one Patriarch, Kallinikos III., died of joy on hearing of his election in I 726. The frequency with which deposition is resorted to is, in fact, the predominant characteristic of the Patriarchate of Constantinople. Many

1 C. D. Cobham, The Patriarchs of Constantinople, Cambridge, I9II. 
Patriarchs have had two, three, four, and five reigns; one, the celebrated Cyril Lucar, had as many as six. The result is that there is almost always a number of ex-Patriarchs of Constantinople who languish in exile, intriguing for their restoration and for the removal of their supplanters, and hoping for better times. Their usual resort is now some monastery of Mount Athos; in former times it was the island of Prinkipo, where their number was such that they found it necessary to build a large commodious house, adorned with spacious gardens, for themselves and their successors-in other words, a residential club for deposed CEcumenical Patriarchs. But singular as have been the vicissitudes which have befallen Patriarchs, only one such prelate, I believe, has had the strange experience of being enrolled as a Janissary. The episode occurred in the latter half of the eighteenth century, in the reign of Sultan Ahmed IV., under the following circumstances :

"The Armenian Patriarch, who resided at Constantinople during the late war (sc., with Russia), having created a suspicion, by some expressions in his sermons, that he was a 
Roman Catholic at heart, the Armenians complained to the Grand Vizir, and obtained an order to send him to the Galleys; but the Patriarch being apprized of his danger, immediately sent for a colonel of the Janissaries, to whom he made known his situation, and prayed to be inlisted into his company, which was accordingly done the same day, and he invited the colonel, with the rest of the officers of his regiment to dine with him at his house the next day, which happened to be Sunday; he officiated as usual, and upon coming out of the church he found one party of Janissaries ready to conduct him to the Galleys, and another to protect him, but the former instantly retired, upon hearing from the latter that the prelate was a Yengi-cheri, a new Janissary, and their officers joined the company at dinner, where they were all very merry at the expence of the Grand Vizir, whose order to arrest the Patriarch was the subject of ridicule."

In view of the fact that the hierarchies of eastern Churches are recruited almost exclusively from the ranks of the monks, there is a marked difference in many respects between the regular and the secular clergy. While a 
few persons may enter monasteries in order to retire from the world, the majority of the monks are eager and ambitious spirits, whose aim is precisely the reverse. But the village papas, who must be married and is thereby deprived of the hope of promotion unless he should chance to become a widower, is a rude and unpretentious person, principally occupied in seeking to supplement his meagre pittance for the support of his numerous brood. No task, however menial, is beneath his dignity; indiscriminately he ploughs and preaches, celebrates the liturgy and tills his field. In a village I know of, the priest darns the linen which his wife, who is a laundress, washes; in another village, in the Cyprus mountains, I have seen a priest, with his ragged cassock tucked in his baggy blue breeches, and with his high black cap, working as a labourer in an asbestos mine. In his leisure hours the papas sits in the coffeeshop with his fellow-villagers, and smokes his hubble-bubble; he makes no claim to be treated with especial deference in virtue of his priestly office, either by his flock or any one else. It will therefore be readily understood that no resentment was evoked whenever the document 
which I quote below was received; it was the form for burial permits for Christians, issued by the Muftis in Turkey from 1695 to 1808 :

"You old priest of evil basis! Wearer of the tar-coloured garment, bearer of the mitre of Satan, ${ }^{1}$ and deprived of access to the Throne of Grace!

"It is reported that infidel - son of infidel —, one of your abominable lot of disbelievers, has become mürd; ${ }^{2}$ and although his loathsome carcass is denied reception even by the soil-yet, what remedy, what remedy, what remedy ? 3

"In order that the noxious stench of it should be done away with, you are to take the corpse outside the town, dig up a ditch, and then cast it thereinto, cover it up with earth, trample, beat it down, and come back ; you old priest!"

1 i.e., the cassock and priest's cap.

2 Mürd olmaq is a contemptuous phrase in Turkish, meaning " to die," which is applied only to Christians. It corresponds more or less to the French word crever.

3 i.e., what remedy is there for the evil? 

IX

\section{THE FALSE MESSIAH}





\section{IX}

\section{THE FALSE MESSIAH}

Although there are few countries where men have not fought and spilled blood ad majorem dei gloriam, it is probably within the regions embraced by the term "the Near East," the cradle of the three greatest religions of the world, that religious conflict has been most violent. Where, as in the Levant, creed is so largely synonymous with nationality, where, indeed, it is often the dominant classification of men, it is natural that this should have been the case; but the conflict is far from being confined to the broad lines which divide one great religion from another. On the contrary, the narrower the field of difference, the fiercer, as a rule, is the animosity which is evoked. Thus, the antagonism between Eastern Christians and Moslems in general is as nothing compared 
with that between Patriarchists and Exarchists in Macedonia, or between the Patriarchate of Antioch on the one hand, and the three other component Patriarchates of the Holy Orthodox Eastern Church on the other. Again, the struggle for the archbishopric of Cyprus, which was pursued with great bitterness from 1900 to I9Io, bit so deeply into the life, not only ecclesiastical but social, of the Christian population of that island, that there arose separate sets of schools for the children of each party, and domestic servants of the opposing factions could not be induced to remain within the same household.

But while the keynote of Near Eastern history and politics has been the ambition of faiths and sects to oust or absorb their rivals, there are to be found in some of the backwaters of the Levant certain small communities which are the outcome of the opposite process, that of compromise. The Druses and Nosayrîyeh in Syria represent attempts to graft an heretical form of Islam on the elements of paganism, dualism, and ancient oriental philosophies. The beliefs of the Stavriotai of Lazistan and of the Linobambakoi of Cyprus are blends of Islam 
and Christianity. The Qizil-bash of Dersim and elsewhere in eastern Anatolia, who on the whole must be classed as a branch of the Shi'as, combine the identities of 'Alî and Our Lord, of 'Alî's sons Hasan and Husein and SS. Peter and Paul, of the twelve Imâms and the twelve Apostles. We even hear of an Armenian sect annually sacrificing sheep to Baal; while the Dönmé of Salonika, of whom this chapter treats, combine an outward acceptance of Islam with their fundamental adherence to a Jewish heresy.

The Turkish word dönmé means a religious convert or pervert, but the members of the sect to which this name is applied by the Turks call themselves "Ma'aminim," believers, or "Habarim," associates. They are the representatives, numbering some ten thousand souls, of one of the most extraordinary movements of the seventeenth century, of a movement which for a time completely disorganized Jewry, not only in the East, but throughout Europe. In the year I666, which, it had been foretold, was to be a year of wonders, one Sabatai or Shabbethai Sevi, a Smyrniote Jew, proclaimed himself the Messiah, and secured 
a large and enthusiastic following among his fellow-Jews. After an amazing career of imposture, attended by signal temporary success, Sabatai was forced, as will be related in detail hereafter, to acknowledge his fraud and to make public profession of Islam. Such, however, was the influence which he had exercised that for a long time his followers could not bring themselves to accept his renunciation of pretensions which they had so firmly believed. Many, indeed, persisted in their faith in him to the end of their lives, some declaring that not Sabatai himself but a demon in his form had done the shameful deed, others, that he was acting a part that he might ultimately secure the conversion of all Moslems to the fold. From these faithful ones the modern Dönmé are descended.

After slumbering in obscurity for more than two centuries, the Dönmé sect has lately acquired a certain political significance in Turkey by reason of the prominence of some of its members in the Committee of Union and Progress; few people, however, know the strange story of its origin. The best account, probably, is that contained in an 
obscure duodecimo volume, rare and difficult of access, which was published in 1683 by one Nathaniel Crouch "at his Shop at the Bell in the Poultrey near Cheapside." 1 The volume contains six relations of divers matters relating to the East, "written by several Englishmen of undoubted veracity and credit, who were upon the places where these remarkable things were transacted"; and as the account of a contemporary and eye-witness is necessarily preferable to a paraphrase, however faithful, I will allow our author, who is anonymous, to speak for himself of the history of the False Messiah :

The Counterfeit Messiah or False Christ of the Jews at Smyrna in the year 1666, written by an English Person of Quality there Resident.

According to the Predictions of several Christian Writers, especially of such who Comment on the Apocalyps, or Revelations, this Year of 1666 was to prove a Year of Wonders, and strange Revolutions in the

1 Tro Journeys to Jerusalem, etc., London, 1683. 
World, and particularly of Blessings to the Jews, either in respect of their Conversion to the Christian Faith, or of their Restoration to their Temporal Kingdoms: This Opinion was so dilated, and fixt in the Countreys of the Reformed Religion as to the downfall of the Pope, and Antichrist, and the Greatness of the Jews, in so much, that this subtle People judged this Year the time to stir, and to fit their Motion according to the season of the Modern Prophesies; whereupon strange Reports flew from place to place of the March of Multitudes of People from unknown parts into the remote Desarts of Arabia, supposed to be the Ten Tribes and half, lost for so many Ages. That a Ship was arrived in the Northern parts of Scotland with her Sails and Cordage of Silk, Navigated by Mariners who spake nothing but Hebrew; with this Motto on their Sails, The Twelve Tribes of Israel. These Reports agreeing thus near to former Predictions, put the wild sort of the World into an expectation of strange Accidents, this year should produce in reference to the Jewish Monarchy.

In this manner Millions of People were 
possessed, when Sabatai Sevi first appear'd at Smyrna, and published himself to the Jews for their.Messiah, relating the greatness of their approaching Kingdom, the strong hand whereby God was about to deliver them from Bondage, and gather them from all parts of the World. It was strange to see how the fancy took, and how fast the report of Sabatai and his Doctrine flew through all parts where Turks and Jews inhabited; the latter of which were so deeply Possessed with a belief of their new kingdom, and Riches, and many of them with promotion to Offices of Government, Renown, and Greatness, that in all parts from Constantinople to Buda (which it was my fortune that year to Travel) I perceiv'd a strange transport in the Jews, none of them attending to any business unless to wind up former negotiations, and to prepare themselves and Families for a Journey to Jerusalem: All their Discourses, their Dreams, and disposal of their Affairs tended to no other Design but a re-establishment in the Land of Promise, to Greatness, Glory, Wisdom, and Doctrine of the Messiah, whose Original, Birth, and Education are first to be recounted. 
Sabatai Sevi was Son of Mordechai Sevi, an Inhabitant, and Natural of Smyrna, who gained his Livelihood by being Broaker to an English Merchant in that place; a person, who before his death was very decrepit in his Body, and full of the Gout, and other Infirmities, but his Son Sabatai Sevi addicting himself to Study, became a notable Proficient in the Hebrew and Metaphysicks; and arrived to that point of Sophistry in Divinity and Metaphysicks, that he vented a New Doctrine in their Law, drawing to the Profession of it so many Disciples, as raised one day a Tumult in the Synagogue; for which afterwards he was by a Censure of the Chochams (who are Expounders of the Law) banished the City.

During the time of his Exile, he Travelled to Thessalonica, now called Salonica, where he Married a very handsome Woman; but either not having that part of Oeconomy as to govern a Wife, or that she found not favour in his Eyes, she was divorced from him: Again he took a second Wife, more beautiful than the former, but the same causes of discontent raising a difference between them, he obtained another Divorce from this Wife also. And 
being now free from the Incumbrances of a Family, his wandring Head mov'd him to Travel through the Morea, thence to Tripoli in Syria, Gaza, and Jerusalem; and by the way picked up a Ligorness Lady, whom he made his third Wife, the Daughter of some Polonian or German, her Original and Parentage not being very well known. And being now at Jerusalem he began to Reform the Law of the Jews, and Abolish the Fast of Tamuz (which they keep in the Month of June) and there meeting with a certain Jew called Nathan, a proper Instrument to promote his Design; he communicated to him his Condition, his Course of Life, and Intentions, to Proclaim himself Messiah of the World, so long expected and desired by the Jeres. This Design took wonderfully with Nathan; and because it was thought necessary according to Scripture, and Antient Prophesies, that Elias was to precede the Messiah, as St. John Baptist was the forerunner of Christ: Nathan thought no man so proper to Act the part of the Prophet as himself; and so no sooner had Sabatai declared himself the Messiah, but Nathan discovers himself to be his Prophet, forbidding all the 
Fasts of the Jews in Jerusalem; and declaring, that the Bridegroom being come, nothing but Joy, and Triumph ought to dwell in their Habitations: Writing to all the Assemblies of the Jews, to perswade them to the same belief. And now the Schism being begun, and many Jews really believing what they so much desired, Nathan took the courage and boldness to Prophesie, That one Year from the $27^{\text {th }}$ of Kisleu (which is the month of June), the Messiah shall appear before the Grand Signior, and take from him his Crown, and lead him in Chains like a Captive.

Sabatai also at Gaza Preached Repentance to the Jews, and Obedience to himself \& Doctrine, for that the coming of the Messiah was at hand: which Novelties so affected the Jewish Inhabitants of those parts, that they gave up themselves wholly to their Prayers, Alms, and Devotions; and to confirm this belief the more, it happened, that at the same time that News hereof, with all particulars were dispatched from Gaza, to acquaint the Brethren in Forrain Parts: The Rumour of the Messiah was flown so swift, and gained such reception, that intelligence came from all 
Parts and Countreys where the Jews inhabit, by Letters to Gaza, and Jerusalem, Congratulating the happiness of their Deliverance, and expiration of the time of their Servitude, by the Appearance of the Messiah. To which they adjoyned other Prophesies, relating to that Dominion the Messiah was to have over all the World: that for 9 Months after he was to disappear ; during which time the Jerws were to suffer, and many of them to undergo Martyrdom : but then returning again Mounted on a Coelestial Lyon, with his Bridle made of Serpents with seven heads, accompanyed with his Brethren the Jews, who Inhabited on the other side of the River Sabatian, he should be acknowledged for the Sole Monarch of the Universe; and then the Holy Temple should descend from Heaven already built, framed, and beautified, wherein they should offer Sacrifice for ever.

And here I leave you to consider, how strangely this deceived People was Amused, when these Confident, and vain Reports, and Dreams of Power, and Kingdoms, had wholly transported them from the ordinary course of their Trade, and Interest.

This noise and rumour of the Messiah, 
having begun to fill all places; Sabatai Sevi resolved to Travel towards Smyrna, the Country of his Nativity; and thence to Constantinople the Capital City, where the principal Work of Preaching was to have been performed: Nathan thought it not fit to be long after him, and therefore Travels by the way of Damascus, where resolving to continue some time for better Propagation of this new Doctrine ; in the mean while Writes the following letter to Sabatai Sevi.

\section{KESVAN OF THIS YEAR.}

To the King; our King, Lord of our Lords, who gathers the Dispersed of Israel, who Redeems our Captivity, the Man elevated to the height of all sublimity, the Messiah of the God of Jacob, the true Messiah, the Coclestial Lyon, Sabatai Sevi, whose Honour be exalted, and his Dominion raised in a short time, and for ever, Amen. After having kissed your hands, and swept the Dust from your Feet, as my Duty is to the King of Kings, whose Majesty be exalted, and his Empire enlarged: These are to make known to the Supream Excellency of that Place, which is adorned with the Beauty of your Sanctity, that the Word of the King, and of his Law, hath enlightned our Faces: that day hath been a solemn 
day unto Israel, and a day of light unto our Rulers, for immediately we applyed our selves to perform. your Command, as our duty is. And though we have heard of many strange things, yet we are couragious, and our heart is as the heart of a Lyon ; nor ought we to enquire a reason of your doings, for your Works are Marvellous, and past finding out: And we are Confirmed in our Fidelity without all exception, resigning up our very Souls for the holiness of your Name: And now we are come as far as Damascus, intending shortly to proceed in our Journey to Scanderone, according as you have commanded us; that so we may ascend, and see the Face of God in light, as the light of the Face of the King of Life: And we, servants of your servants, shall cleanse the dust from your Feet, beseeching the Majesty of your Excellency and Glory to vouchsafe from your habitation to have a care of us, and help us with the Force of your Right Hand of Strength, and shorten our way which is before us: And we have Eyes towards Jah, Jah, who will make hast to help us, and save us, that the Children of Iniquity shall not hurt us; and towards whom our hearts pant, and are consumed within us: who shall give us Tallons of Iron to be worthy to stand under the shadow of your Asse. These are the words of the Servant of your servants, who prostrates himself to be trod on by the sole of your feet,

Nathan Benjamine. 
And that he might Publish this Doctrine of himself, and the Messiah more plainly, he Wrote from Damascus this following Letter, to the Jews at Aleppo, and parts thereabouts.

To the Residue or Remnant of the Israelites, Peace without end.

These my words are to give you notice, how that I am arrived in peace at Damascus, and behold I go to meet the Face of our Lord, whose Majesty be exalted, for he is the Soveraign of the King of Kings, whose Empire be enlarged. According as he hath Commanded us and the 12 Tribes to elect unto him I 2 Men, so have we done: And we now go to Scanderone by his command, to shew our faces together with part of the principal of those particular Friends to whom he hath given Licence to assemble in that same place. And now I come to make known unto you, that though you have heard strange things of our Lord, yet let not your hearts faint, or fear, but rather, fortifie your selves in your Faith, because all his Actions are Miraculous, and Secret, which Humane understanding cannot comprehend, and who can penetrate into the depth of them. In a short time all things shall be Manifested to you clearly in their Purity: and you shall know, and consider, and be instructed by the Inventor himself; Blessed is he who can expect, and arrive to the 
Salvation of the true Messiah, who will speedily publish his Authority and Empire over us now, and for ever.

NATHAN.

And now all the Cities of Turky where the Jews Inhabited were full of the expectation of. the Messiah; no Trade nor course of Gain was followed: every one imagin'd that dayly Provisions, Riches, Honours, and Government, were to descend upon them by some unknown and Miraculous manner: an Example of which is most observable in the Jews at Thessalonica, who now, full of Assurance that the Restoration of their Kingdom and the Accomplishment of the time for the coming of the Messiah was at hand, judged themselves obliged to double their Devotions, and Purifie their Consciences from all Sins and Enormities which might be obvious to the scrutiny of him who was now come to Penetrate into the very Thoughts and Imaginations of Mankind. In which Work certain Chochams or Priests were appointed to direct the People how to Regulate their Prayers, Fasts, and other Acts of Devotion. But so forward was every one now in his Acts of Penance, that they stay'd not for the Sentence 
of the Chocham, or prescription of any Rules, but apply'd themselves immediately to fasting : And some in that manner beyond the abilities of Nature, that having for the space of seven days taken no sustenance, were famished to death. Others buryed themselves in their Gardens, covering their naked Bodies with Earth, their heads onely excepted remained in their Beds of dirt until their Bodies were stiffned with the cold and moisture: others would indure to have melted Wax dropt upon their Shoulders, others to rowl themselves in Snow, and throw their Bodies in the Coldest season of Winter into the Sea, or Frozen Waters. But the most common way of Mortification was first to prick their Backs and Sides with Thorns, and then to give themselves thirty nine Lashes. All business was laid aside, none wrought, or opened Shop, unless to clear his Warehouse or Merchandize at any Price: who had superfluity in Housholdstuff, sold it for what he could; but yet not to Jews, for they were Interdicted from Bargaines or Sales, on the pain of Excommunication, Pecuniary Mulcts, or Corporal Punishments; for all Business and Imployment was esteemed the Test, and Touch- 
stone of their Faith. It being the general Tenent, that in the days that the Messiah appears, the Jews shall become Masters of the Estates and Inheritance of Infidels; until when they are to content themselves with Matters onely necessary to maintain and support Life, but because every one was not Master of so much Fortune and Provision, as to live without dayly Labour, therefore to quiet the Clamours of the Poor, and prevent the Enormous lives of some, who upon these occasions would become Vagabonds and desert their Cities, due order was taken to make Collections, which were so liberally bestowed that in Thessalonica onely 400 Poor were supported by the meer charity of the Richer. And as they indeavour'd to purge their Consciences of Sin, and to apply themselves to good Works, that the Messiah might find the City prepared for his Reception; so lest he should accuse them of any omission in the Law, and particularly in their neglect of that Antient Precept of Increase and Multiply; they marryed together Children of ten years of age, and some under, without respect to Riches, or Poverty, Condition of Quality: but, being promiscuously joyned, to 
the number of 6 or 700 Couple, upon better and cooler thoughts, after the deceipt of the false Messiah was discover'd, or the expectation of his Coming grew cold, were Divorced, or by Consent separated from each other.

In the heat of all this Talk and Rumor comes Sabatai Sevi to Smyrna, the City of his Nativity, infinitely desired there by the common Jews; but by the Chochams, or Doctors of their Law, who gave little or no credence to what he pretended, was ill received, not knowing what mischief or ruine this Doctrine and Prophesie of a New Kingdom might produce. Yet Sabatai bringing with him testimonials of his Sanctity, Holy Life, Wisdom, and gift of Prophesie, so deeply fixed himself in the heart of the Generality, both as being Holy and Wise, that thereupon he took courage and boldness to enter into Dispute with the Grand Chocham (who is the Head, and Chief Expositor of the Law and super-intendent of their will and Government) between whom the Arguments grew so high, and Language so hot, that the Jerws who favoured the Doctrine of Sabatai, and feared the Authority of the Chocham, doubtful what might be the issue of 
the Contest, appeared in great numbers before the Cadi of Smyrna, in justification of their New Prophet, before so much as any Accusation came against him: The Cadi (according to the Custom of the Turks), swallows Mony on both sides, and afterwards remits them to determination of their own Justice. In this manner Sabatai gains ground dayly; and the Grand Chocham with his Party, losing both the affection and obedience of his People, is displaced from his Office, and another Constituted, more affectionate, and agreeable to the New Prophet whose power daily increased by those confident Reports, That his enemies were struck with Phrensies and Madness, until being restored to their former temper and wits by him, they became his Friends, Admirers, and Disciples. No Invitation was now made in Smyrna by the Jews, nor Marriage, or Circumcision solemnized, where Sabatai was not present, accompanied with a multitude of his Followers, and the Streets cover'd with Carpets, or fine Cloath for him to tread on; but the Humility of this Pharisee appeared such that he would stoop and turn them aside, and so pass. And having thus fixed himself in the 
Opinion and Admiration of the People, he began to take on himself the Title of Messiah, and the Son of God and to make this following Declaration to all the Nation of the Jews which being writ Originally in Hebrew, is thus Translated into English.

The Only, and first-born Son of God, Sabatai Sevi, the Messiah and Saviour of Israel, to all the Sons of Israel, peace. Since that you are made worthy to see that great Day of Deliverance, and Salvation unto Israel, and Accomplishment of the word of God, Promised by his Prophets, \& our forefathers, \& by his Beloved son of Israel: let your bitter sorrows be turned into Joy, and your Fasts into Festivals, for you shall weep no more, $\mathrm{O}$ my sons of Israel, for God having given you this unspeakable comfort, rejoyce with Drums, Organs, and Musick, giving thanks to him for performing his Promise from all Ages; doing that every day, which is usual for you to do upon the New-Moons; and, that Day Dedicated to affliction and sorrow convert you into a Day of Mirth for my appearance: and fear you nothing, for you shall have Dominion over the Nations, and not only over those who are on Earth, but over those Creatures also which are in the depth of the Sea, All which is for your Consolation and Rejoycing.

Sabatai Sevi. 
Notwithstanding the Disciples of Sabatai Sevi were not so numerous, but many opposed his doctrine, publiquely avouching that he was an Impostor, and Deceiver of the people, amongst which was one Samuel Pennia, a man of a good estate \& reputation in Smyrna, who arguing in the Synagogue, that the present signs of the coming of the Messiah were not apparent, either according to Scripture, or the doctrine of the Rabbins, raised such a sedition and tumult amongst the Jews, as not only prevailed against arguments, but had also against his life, had he not timely conveyed himself out of the Synagogue, and thereby escaped the hands of the multitude, who now could more easily endure blasphemy against the Law of Moses, and the prophanation of the Sanctuary, than contradiction, or mis-belief of the doctrine of Sabatai. But howsoever it fell out, Pennia in short time becomes a convert, and preaches up Sabatai for the Son of God, and deliverer of the Jews: and not only he, but his whole family; his daughters prophesie, and fall into strange extasies; and not only his own house, but four hundred men and women prophesie of the growing kingdom of 
Sabatai, and young infants who could yet scarce stammer out a syllable to their mothers, repeat, and pronounce plainly the name of Sabatai the Messiah, and Son of God. For thus far had God permitted the Devil to delude this people, that their very children were for a time possessed, and voices heard to sound from their stomacks, and intrails: those of riper years fell first into a trance, foamed at the mouth, and recounted the future prosperity, and deliverance of the Israelites, their visions of the Lyon of Judah, and the triumphs of Sabatai, all which were certainly true, being effects of Diabolical delusions: as the Jews themselves since have confessed unto me.

With these concomitant accidents, and successes, Sabatai Sevi growing more presumptuous, that he might correspond with the Prophesies of the greatness, \& dominion of the Messiah, proceeds to an election of those Princes which were to govern the Israelites in their march towards the Holy-Land, and to dispense Judgment and Justice after their Restoration. The names of them were these which follow, men well known at Smyrna, who never (God knows) had ambition to aspire to 
the title of Princes, until a strange spirit of deceit and delusion had moved them, not only to hope for it as possible, but to expect as certain.

Isaac Silvera.

Salomon Legnado

Salom. Lagnado jun.

Joseph Cophen.

Moses Galente.

Daniel Pinto.

Abraham Scandale.

Mokiah Gaspar.

Abraham Leon.

Ephraim Arditi.

Salom Carmona.

Matassia Aschenesi.

Meir Alcaira.

Jacob Loxas.

Mordecai Jesserun.

Chaim Inegna.

Joseph Scavillo.

Conor Nehemias

Joseph del Caire

Eleukin Schavit.

Abraham Rubio.
King David.

was Salomon.

named Quovah.

Uzziah.

Josaphat.

Hilkiah.

Jotham.

Zedekiah.

Achas.

Joram.

Achab.

Asa.

Rehoboan.

Ammon.

Jehoachim.

Jeroboam.

Abia.

was Zorobabel. named Joas.

Amasia.

Josiah.

Elias Sevi had the title of the King of the king of kings. 
Elias Azar his Vice-king, or Vizier.

Joseph Sevi, the king of the kings of Judah.

Joseph Inernuch his vice-king.

In this manner things ran to a strange height of madness amongst the Jews at Smyrna, where appeared such pageantry of greatness, that no Comedy could equal the mock-shews they represented, and though none durst openly profess any scruple, or doubt of this common received belief, yet for confirmation of the Jews in their Faith, and astonishment of the Gentiles, it was judged no less than necessary that Sabatai should shew some miracles whereby to evince to all the World that he was the true Messiah: and as the present occasion seemed to require an evidence infallible of this truth, so it was daily expected by the vulgar, with an impatience suitable to humors disposed to Novelty; who out of every action and motion of their Prophet began to fancy something extraordinary and supernatural. Sabatai was now horribly puzzled for a Miracle, though the imagination of the people was so vitiated that any Legerdemain or slight of hand would have passed more easily with them for a wonder than Moses striking the rock for 
water, or dividing the Red sea. And an occasion happening that Sabatai was, in behalf of his Subjects, to appear before the Cadi, or judge of the City to demand ease, and relief of some oppressions which aggrieved them: It was thought necessary a Miracle should now or never [sc. be shown], when Sabatai appearing with a formal pharisaical gravity, which he had starcht on: Some on a sudden avouched to see a Pillar of fire between him and the Cadi, which report presently was heard through the whole room, filled with Jews that accompanied Sabatai, some of whom, who strongly fancied it, vow'd, and swore they saw it : others in the outward yard, or that could not come near to hear, or see for the crowd, as speedily took the alarm, and the rumour ran, and belief receiv'd by the Women and Children at home in a moment, so that Sabatai Sevi returned to his house triumphant, fixed in the hearts of his people, who now needed no further Miracles to confirm them in their faith. And thus was Sabatai exalted, when no man was thought worthy of communication who did not believe him to be the Messiah: others were called Kophrim, infidels or hereticks, liable to the censure of 
excommunication with whom it was not lawful so much as to eat: every man produced his treasure, his Gold and Jewels, offering them at the feet of Sabatai; so that he could have commanded all the wealth of Smyrna, but he was too subtil to accept their money, lest he should render his design suspected by any act of covetousness. Sabatai Sevi having thus fully fixed himself in Smyrna, and filled other places with rumours of his fame, declared that he was called by God to visit Constantinople, where the greatest part of his work was to be accomplisht ; in order whereunto he privately ships himself, with some few attendants in a Turkish Saick, in the Month of January, i666, lest the crowd of his disciples, and such who would press to follow him, should endanger him in the Eyes of the Turks, who already began to be scandalized at the reports and prophesies concerning his person. But though Sabatai took few into the Vessel to him, yet a multitude of Jews travelled over land to meet him again at Constantinople, on whom all their Eyes and Expectations were intent. The wind proving northernly, as commonly it is in the Hellespont and Propontis; Sabatai was thirty nine days in 
his voyage, and yet the Vessel not arriv'd, so little power had this Messiah over the Sea and Winds, in which time news being come to Constantinople that the Jews' Messiah was near, all that people prepared to receive him with the same Joy and Impatience as was exprest in other parts where he arrived; the great Vizier (then also at Constantinople, being not yet departed on his expedition for Candia) having heard some rumours of this man, and the disorder \& madness he had raised amongst the Jerws; sent two Boats, whil'st the Saick was detained by contrary winds, with commands to bring him up Prisoner to the Port, where accordingly Sabatai being come, was committed to the most loathsome and darkest Dungeon in the Town, there to remain in farther expectation of the Viziers sentence: The Jezes were not at all discouraged at this ill treatment of their Prophet, but rather confirmed in their belief of him, as being the accomplishment of the prophesie of those things which ought to preceed his glory and dominion; which consideration induc'd the chiefest persons amongst the Jerws to make their visits and addresses to him with the same ceremony and respect in 
the Dungeon as they would have done had he then sat exalted on the throne of Israel: several of them, with one Anacago, by name, a man of great esteem amongst the Jews, attended a whole day before him, with their Eyes cast down, their bodies bending forward, and hands crost before them (which are postures of humility, and service in the Eastern Countreys) the undecency of the place, and present subjection, not having in the least abated their high thoughts, and reverence towards his person. The Jews in Constantinople were now become as mad and distracted as they were in other places, all trade and traffique forbidden, and those who owed money, in no manner careful how to satisfie it: amongst which wild crew some were indebted to our Merchants at Galata, who not knowing the way to receive their money, partly for their interest, and partly for curiosity thought fit to visit this Sabatai complaining that such particular Jews, upon his coming, took upon them the boldness to defraud them of their right, desired he would be pleased to signifie to these his Subjects, his pleasure to have satisfaction given: whereupon Sabatai with 
much affectation took Pen and Paper, and wrote to. this effect.

To you of the Nation of the Jerws, who expect the appearance of the Messiah and the Salvation of Israel, Peace without end. Whereas we are informed that you are indebted to several of the English Nation : It seemeth right unto us to enorder you to make satisfaction to these your just debts : which if you refuse to do, and not obey us herein: Know you, that then you are not to enter with us into our Joys and Dominions.

In this manner Sabatai Sevi remained a Prisoner at Constantinople for the space of two Months ; at the end of which the Vizier having designed his expedition for Candia; and considering the rumor and disturbance the presence of Sabatai had made already at Constantinople, thought it not secure to suffer him to remain in the Imperial City, whil'st both the Grand Signior and himself were absent : and therefore changes his prison to the Dardanelli, otherwise called the Castle of Abydos, being on the Europe side of the Hellespont opposite to Sestos, places famous in Greek Poetrie. This removal of Sabatai from a worse Prison to one of a better air, confirmed the Jeres with greater 
confidence of his being the Messiah, supposing that had it been in the power of the Vizier, or other Officers of the Turks, to have destroyed his person, they would never have permitted him to have lived to that time; in regard their Maxims enforce them to quit all jealousies and suspitions of ruine to their state by the death of the party feared, which much rather they ought to execute on Sabatai, who had not onely declared himself the King of Israel, but also published Prophesies fatal to the Grand Signior and his Kingdoms.

With this consideration, and others preceding, the Jews flock in great number to the Castle, where he was imprisoned [sc. with those] not onely from the neighbouring parts but also from Poland, Germany, Legorn, Venice, Amsterdam, and other places where the Jews reside: on all whom, as a reward or the expence, and labours of their pilgrimage, Sabatai bestowed plenty of his benedictions, promising encrease of their store, and enlargement of their Possessions in the Holy-Land. And so great was the confluence of the Jeres to this place, that the Turks thought it requisite to make their advantage thereof, and so not onely 
raised the price of their Provisions, Lodgings, and other Necessaries, but also denied to admit any to the presence of Sabatai, unless for money setting the price sometimes five, sometimes at ten Dollars, or more or less, according as they guessed at their abilities, or zeal of the person, by which gain and advantage to the Turks no complaints or advices were carried to Adrianople, either of the concourse of people, or arguments amongst the Jews in that place but rather all civilities, and liberty indulged unto them, which served as a farther argument to ensnare this poor people in the belief of the Messiah.

During this time of confinement, Sabatai had leisure to compose and institute a new method of Worship for the Jews, and principally the manner of the celebration of the day of his Nativity, which he prescribed in this manner.

Brethren, and my People, men of Religion inhabiting the City of Smyrna the renowned, where live men, and women, and families; Peace be unto you from the Lord of Peace, and from me his beloved son, King Salomon. I command you that the ninth day of the Month of $A b$ (which according to our account answered that year to the Month of 
June) next to come, you make a day of Invitation, and of great joy, celebrating it with choice meats and pleasing drinks, with many Candles and Lamps, with Mastick and Songs, because it is the day of the Birth of Sabatai Sevi, the high King above all kings of the Earth. And as to matters of labour, and other things of like nature, do, as becomes you, upon a day of Festival, adorned with your finest garments. As to your Prayers, let the same order be used as upon Festivals. To converse with Christians on that day is unlawful, though your Discourse be matters indifferent, all labour is forbidden, but to sound instruments is lawful. This shall be the method and substance of your Prayers on this day of Festival : After you have said, Blessed be thou, $O$ holy God! then proceed and say, Thou hast chosen us before all people, and hast loved us, and hast been delighted with us, and hast humbled us more than all other Nations, and hast sanctified us with thy service, and the service of our King. Thy holy,great, and terrible Name thou hast published amongst us : and hast given us, O Lord God, according to thy love, times of joy, of Festivals, and times of Mirth, and this day of Consolation for a solemn Convocation of Holiness, for the birth of our King the Messiah, Sabatai Sevi thy servant, and first-born son of love, through whom we commemorate our coming out of Egypt. And then you shall read for your lessons I, 2, and 3 Chapters of Deut. to the 
I7. verse, appointing for the reading thereof five men, in a perfect \& uncorrupted Bible, adding thereunto the Blessings of the Morning, as are prescribed for days of Festival : and for the Lesson out of the Prophets usually read in the Synagogue every Sabbath; you shall read the 3 I Chapt. of Jeremiah. To your Prayer called Mussaf (used in the Synagogue every Sabbath and solemn Festival) you shall adjoyn that of the present Festival; In stead of Sacrifice of Addition, of the returning of the Bible to its place, you shall read with an Audible Voice, Clear Sound, the Psalm 95. And at the first Praises in the Morning, after you have Sung Psalm 9I, and just before you Sing Psalm 98, you shall repeat Psalm I 32, but in the last Verse, where it is said, As for his Enemies, I shall cloath them with shame, but upon himself shall his Crown flourish; in the place of (upon himself) you shall read upon the most High: after which shall follow the I 26. Psalm, and then the I I 3. to the I I 9.

At the Consecration of the Wine upon the Vigil, or Eve, you shall make mention of the Feast of Consolation, which is the day of the Birth of our King the Messiah Sabatai Sevi thy Servant, and first-born Son, giving the Blessing as followeth: Blessed be thou our God, King of the World, who hast made us to live, and hast maintain'd us, and hast kept us alive unto this time. Upon the Eve of that day you shall Read also the 8I Psalm, as 
also the I32. and I 26. Psalms which are appointed for the Morning Praises. And this day shall be unto you for a Remembrance of a Solemn Day unto eternal Ages, and a perpetual testimony between $\mathrm{me}$, and the Sons of Israel.

Audite Audiendo \& manducate bonum.

In hearing hear, and enjoy good.

Besides which Order, and Method of Prayers for Solemnization of his Birth, he prescribed other Rules for Divine Service, and particularly published the same Indulgence and Priviledge to every one who should Pray at the Tomb of his Mother; as if he had taken on him a Pilgrimage to Pray, and Sacrifice at Jerusalem.

The Devotion of the Jews towards this pretended Messiah increased still more and more, so that [sc. not] onely the Chief of the City went to attend, and proffer their service toward him in the time of his Imprisonment, but likewise decked their Synagogue with S. S. in Letters of Gold, making for him on the Wall a Crown, in the Circle of which was wrote the 9 I Psalm at length in fair and legible Characters; attributing the same titles to Sabatai, and expounding the Scriptures in the same manner 
in favour of his Appearance, as we do of our Saviour. However some of the Jerws remained in their Wits all this time amongst which was a certain Chocham, at Smyrna, one zealous of his Law, and of the good and safety of his Nation: and observing in what a wilde manner the whole People of the Jews was transported with the groundless belief of a Messiah leaving not only their Trade, and course of living, but publishing Prophesies of a speedy Kingdom, of rescue from the Tyranny of the Turk, and leading the Grand Signior himself Captive in Chains ; matters so dangerous and obnoxious to the State wherein they lived, as might justly convict them of Treason and Rebellion, and leave them to the Mercy of that Justice, which on the least jealousie and suspicion of Matters of this nature, uses to extirpate Families, and subvert the Mansionhouses of their own People, much rather of the Jerws, on whom the Turks would gladly take occasion to dispoil them of their Estates, and condemn the whole Nation to perpetual slavery. And indeed it would have been a greater wonder than ever Sabatai shewed, that the Turks took no advantage from all these ex- 
travagances, to drein the Jews of a considerable Sum of money, and set their whole Race in Turkey at a Ransome, had not these Passages yielded them matter of Pastime and been the Subject of the Turks Laughter and Scorn; supposing it a Disparagement to the greatness of the Ottoman Empire, to be concerned for the Rumors and Combustions of this dispersed People. With these considerations this Chocham, that he might clear himself of the blood and guilt of his Countrey-men, and concern'd in the common destruction, goes before the Cadi, and there protests against the present Doctrine; Declaring, that he had no hand in setting up of Sabatai, but was an Enemy both to him and to his whole Sect. This freedom of the Chocham so enraged and scandalized the Jerws, that they judged no Condemnation or Punishment too severe against such an Offender and Blasphemer of their Law, and Holiness of the Messiah; and therefore with Money and Presents to the Cadi, accusing him as disobedient in a Capital nature to their Government, obtained sentence against him, to have his Beard shaved and to be condemned to the Gallies. There wanted nothing now to the appearance of the Messiah, 
and the solemnity of his coming, but the presence of Elias, whom the Jews began to expect hourly, and with that intention and earnestness, that every Dream, or Phantasme to a weak head was judged to be Elias; it being taught, and averred, that he was seen in divers forms and shapes, not to be certainly discovered or known, before the coming of the Messiah; for this superstition is so far fixed amongst them, that generally in their Families they spread a Table for Elias the Prophet, to which they make an Invitation of Poor people, leaving the chief place for the Lord Elias, whom they believe to be invisibly present at the entertainment, and there to Eat; and Drink, without dimunition, either of the Dishes, or of the Cup. One person amongst the Jews commanded his Wife after a supper of this kind, to leave the Cup filled with Wine, and the Meat standing all night, for Elias to Feast, and Rejoyce alone ; And in the morning arising early, affirmed, that Elias took his Banquet so kindly, that in token of gratitude, and acceptance, he had replenished the Cup with Oyl, in stead of Wine. It is a certain Custom amongst the Jews on the Evening of the Sabbath, to repeat 
certain Praises of God (called Havdila) which signifies a distinction, or separation of the Sabbath from the prophane days (as they call them) which Praises they observe to perform in this manner. One takes a Cup filled with Wine, and drops it through the whole House, saying, Elias the Prophet, Elias the Prophet, Elias the Prophet, come quickly to us with the Messiah, the Son of God, and David; and this they affirm to be so acceptable to Elias, that he never fails to preserve that family, so devoted to him, and augment it with the blessings of Increase. Many other things the Jews avouch of Elias, so ridiculous, as are not fit to be declar'd, amongst which this one is not far from our purpose that at the Circumcision there is always a Chair set for Elias: and Sabatai Sevi being once Invited at Smyrna to the Circumcision of the First-born-Son of one Abraham Gutiere, a Kinsman of Sabatai, and all things ready for the Ceremony, Sabatai Sevi exhorted the Parents of the Child to expect a while until his farther Order: After a good half hour, Sabatai order'd them to proceed and cut the Prepuce of the Child, which was instantly perform'd with all joy and satis- 
faction to the Parents: and being afterwards demanded the reason why he retarded the performance of that Function, his answer was, That Elias had not as yet taken his Seat, whom, as soon as he saw placed, he ordered them to proceed; and that now shortly Elias would discover himself openly, and proclaim the news of the general Redemption.

This being the common Opinion amongst the Jews, and that Sabatai Sevi was the Messiah, being become an Article of Faith, it was not hard to perswade them, that Elias was come already, that they met him in their Dishes, in the dark, in their Bed-chambers, or any where else invisible, in the same manner as our common People in England believe of Hobgoblins \& Fairies. For so it was, when Solomon Cremona, an Inhabitant of Smyrna, making a great Feast, to which the Principal Jews of the City were Invited, after they had eaten and drank freely, one starts from his Seat, and vouches that he saw Elias upon the Wall, and with that bows to him, and Complements him with all Reverence and humility: Some others having in like manner their Fancies prepossessed, and their Eyes with the 
Fume of Wine ill prepared to distinguish shadows, immediately agreed upon the Object, and then there was not one in the Company who would say he did not see him : at which surprize every one was struck with reverence and awe; and the most Eloquent amongst them, having their Tongues loosed with joy, and Wine, directed Orations, Encomiums, and acts of Thankfullness to Elias, courting and complementing him, as distracted Lovers do the supposed presence of their Mistresses. Another Jew at Constantinople reported that he met Elias in the Streets, habited like a Turk, with whom he had a long Communication; and that he enjoyn'd the Observation of many neglected Ceremonies, and particularly the Zezit, Numb. 15. v. 38. Speak unto the Children of Israel, and bid them that they make Fringes in the Borders of their Garments, throughout their Generations, and that they put upon the Fringe of the Border a Ribbon of blue. Also the Peos, Levit. 19. v. 27. Ye shall not round the corners of your Head, nor marr the corners of your Beard: This Apparition of Elias being believed as soon as published, every one began to obey the Vision, by Fring- 
ing their Garments; and for their Heads, though always shaved, according to the Turkish and Eastern Fashion, and that the suffering Hair to grow, to men not accustomed, was heavy, and incommodious to their healths and heads; yet to begin again to renew as far as possible, the antient Ceremonies, every one nourished a lock of hair on each side, which might be visible beneath their Caps; which soon after began to be a Sign of distinction between the Believers and Kophrims, a name of dishonour, signifying as much as Unbelievers; or Hereticks, given to those who confessed not Sabatai to be the Messiah; which particulars, if not observed, it was declared, as a Menace of Elias, that the People of the Jerws, who come from the River Sabation, as is specifyed in the second of Esdras, Chap. I 3. shall take vengeance of those who are guilty of these Omissions.

But to return again to Sabatai Sevi himself, we find him still remaining a Prisoner in the Castle of Abydos upon the Hellespont, admired and adored by his Brethren, with more honour than before, and visited by Pilgrims from all parts where the fame of the coming of the Messiah had arrived; amongst which one from 
Poland, named Nehemiah Cohen, was of special note and renown, learned in the Hebrew, Syriack, and Chaldee, and versed in the Doctrine and Kabala of Rabines, as well as Sabatai himself, one (of whom it was said) had not this Sevi anticipated the Design, esteemed himself as able a Fellow to Act the Part of a Messiah as the other: Howsoever, it being now too late to publish any such Pretence, Sabatai having now eleven Points of the Law by Possession of the Office, and with that the hearts and belief of the Jews, Nehemiah was contented with some small appendage, or elation to a Messiah; and therefore to lay his Design the better, desired a Private Conference with Sabatai: These two great Rabbins being together, a hot Dispute arose between them; For Cohen alledged that according to Scripture, and Exposition of the Learned thereupon, there were to be two Messiahs, one called Ben Ephraim, and the other Ben David: the first was to be a Preacher of the Law, poor, and despised, and a Servant of the Second, and his Fore-runner; the other was to be great and rich, to restore the Jews to Jerusalem, to sit upon the Throne of David, and to perform and 
act all those Triumphs and Conquests which were expected from Sabatai. Nehemiah was contented to be Ben Ephraim, the afflicted and poor Messiah and Sabatai (for any thing I hear) was well enough contented he should be so: but that Nehemiah accused him for being too forward in publishing himself the latter Messiah, before Ben Ephraim had first been known unto the World Sabatai took this reprehension so ill, either out of pride, and thoughts of his own infallibility, or that he suspected Nehemiah, being once admitted for Ben Ephraim, would quickly (being a subtile and learned person) perswade the World that he was Ben David, would by no means understand or admit of this Doctrine, or of Ben Ephraim for a necessary Officer: And thereupon the Dispute grew so hot, and the Controversie so irreconcileable, as was taken notice of by the Jews, and controverted amongst them as every one fancy'd : But Sabatai being of greater Authority, his Sentence prevailed and Nehemiah was rejected, as Schismatical, and an Enemy to the Messiah, which afterward proved the ruin and downfall of this Impostor.

For Nehemiah being thus baffled, and being 
a person of Authority, and a haughty Spirit, meditated nothing but revenge; to execute which to the full, he takes a Journey to Adrianople, and there informs the Chief Ministers of State, and Officers of the Court, who (by reason of the gain the Turks made of their Prisoner at the Castle on the Hellespont) heard nothing of all this Concourse of People, and Prophesies of the Revolt of the Jews from their Obedience to the Grand Signior; and taking likewise to his Councel some certain discontented and unbelieving Chochams, who being zealous for their Nation, and jealous of the ill-consequences of this long-continued, and increasing Madness, took liberty to inform the Chimacham (who was Deputy of the great Vizier then at Candia) that the Jew, Prisoner at the Castle, called Sabatai Sevi, was a Lewd Person, and one who indeavoured to debauch the minds of the Jeres, and divert them from their honest course of livelihood, and Obedience to the Grand Signior; and that therefore it was necessary to clear the World of so Factious and dangerous a Spirit: the Chimacham being thus informed, could do no less than acquaint the Grand Signior with all the particulars of this 
Mans Condition, Course of Life, and Doctrine ; which were no sooner understood, but a Chiaux, or Messenger, was immediately dispatched, to bring up Sabatai Sevi to Adrianople. The Chiaux executed his Commission after the Turkish fashion in hast, and brought Sabatai in a few days to Adrianople, without further excuse or ceremony; not affording him an hours space to take a solemn farewell of his Friends, his Followers and Adorers ; who now were come to the vertical point of all their hopes and expectations.

The Grand Signior having by this time received divers informations of the madness of the Jews, and the pretences of Sabatai; grew big with desire and expectation to see him : so that he no sooner arrived at Adrianople, but the same hour he was brought before the Grand Signior: Sabatai appeared much dejected, and failing of that courage which he shewed in the Synagogue; and being demanded several Questions in Turkish by the Grand Signior, he would not trust so far to the vertue of his Messiahship, as to deliver himself in the Turkish Language; but desired a Doctor of Physick (who had from a Jew turned Turk) to 
be his interpreter, which was granted to him; but not without reflection of the standers by ; that had he been the Messiah, and Son of God, as he formerly pretended his tongue would have flown with variety, as well as with the perfection of Languages. But the Grand Signior would not be put off without a Miracle, and it must be one of his own choice: which was, that Sabatai should be stript naked, and set as a mark to his dexterous Archers : if the Arrows peirced not his body, but that his flesh and skin was proof like armour, then he would believe him to be the Messiah, and the person whom God had designed to those Dominions, and Greatnesses, he pretended. But now Sabatai not having faith enough to stand to so sharp a trial, renounced all his title to Kingdoms and Governments, alledging that he was an ordinary Chocham, and a poor Jew, as others were, and had nothing of Priviledge, or Vertue above the rest. The Grand Signior notwithstanding, not wholly satisfied with this plain confession, declared, that having given publique scandal to the Professors of the Mahometan religion, and done dishonour to his Soveraign authoritie, by pretending to draw such a considerable portion 
from him, as the Land of Palestine; his treason and crime was not to be expiated by any other means then by a conversion to the Mahometan faith, which if he refus'd to do, the stake was ready at the gate of the Seraglio to empale him. Sabatai being now reduced to extremity of his latter game; not being the least doubtful what to do; for to die for what he was assured was false, was against nature, and the death of a mad man: replyed with much cheerfulness, that he was contented to turn Turk, and that it was not of force, but of choice, having been a long time desirous of so glorious a Profession, he esteemed himself much honoured, that he had opportunity to own it first in the presence of the Grand Signior. And here was the non plus ultra of all the bluster and noise of this vain Impostor. And now the Reader may be pleased to pause a while, and contemplate the strange point of consternation, shame, and silence to which the Jews were reduc't, when they understood how speedily their hopes were vanished, and how poorly and ignominiously all their fancies and promises of a new Kingdom, their Pageantry, and Offices of Devotion, were put like a tale, or a midnights dream: And all 
this was concluded, and the Jews sunk on a sudden, and fallen flat in their hopes, without so much as a line of comfort, or excuse from Sabatai, more than in general, to all the brethren: That now they should apply themselves to their Callings and services of God, as formerly, for that matters relating unto him were finished and the sentence past. The news that Sabatai was turned Turk, and the Messiah to a Mahometan, quickly filled all parts of Turky. The Jews were strangely surprized at it, and ashamed of their easie belief of the arguments with which they had perswaded one the other, and of the Proselytes they had made in their own families. Abroad they became the common derision of the Towns where they inhabited: the Boys houted after them, coyning a new word at Smyrna (Ponstai) which every one seeing a Jew, with a finger pointed out, would pronounce with scorn and contempt: so that this deceived people for a long time after remained with confusion, silence, and dejection of Spirit. And yet most of them affirm that Sabatai is not turned Turk, but his shadow only remains on earth, and walks with a white head, and in the habit of a Mahumetan : 
but that his natural body and soul are taken into heaven, there to reside until the time appointed for accomplishment of these wonders : and this opinion began so commonly to take place, as if this people resolved never to be undeceived, using the forms and rules for Devotion prescribed them by their Mahumetan Messiah: Insomuch that the Chochams of Constantinople, fearing the danger of this error might creep up, and equal the former, condemned the belief of Sabatai being Messiah, as damnable, and enjoyned them to return to the antient Method and Service of God upon pain of Excommunication. The style and tenure of them was as followeth,

To you who have the power of Priesthood, and are the knowing, learned, and magnanimous Governours and Princes, residing in the City of Smyrna, may the Almighty God protect you, Amen: for so is his will.

These our Letters, which we find in the midst of your habitations, are upon occasion of certain rumors and tumults come to our ears from that City of your Holiness. For there is a sort of men amongst you, who fortifie themselves in their error, and say, let such a one our King, live, and bless him in their 
publique Synagogues every Sabbath day: And also adjoyn Psalms and Hymns, invented by that man, for certain days, with Rules and Methods for Prayer, which ought not to be done, and yet they will still remain obstinate therein; and now behold it is known unto you, how many swelling Waters have passed over our Souls for his sake, for had it not been for the Mercies of God, which are without end, and the merit of our forefathers, which hath assisted us; the foot of Israel had been rased out by their enemies. And yet you continue obstinate in things which do not help, but rather do mischief, which God avert. Turn you therefore, for this is not the true way, but restore the Crown to the antient custom and use of your forefathers, and the law, and from thence do not move; We command you that with your authority under pain of Excommunication, and other penalties, that all those Ordinances and Prayers, as well those delivered by the mouth of that man, as those which he enjoyned by the mouth of others, be all abolished and made void, and to be found no more, and that they never enter more into your hearts, but judge according to the ancient commandment of your Forefathers, repeating the same Lessons and Prayers every Sabbath, as hath been accustomary, as also Collects for Kings, Potentates, and anointed, \&c. And bless the King, Sultan Mahomet, for in his days hath great Salvation been wrought for Israel, and become not Rebels to his Kingdom, 
which God forbid. For after all this which is past, the least motion will be a cause of jealousie, and you will bring ruine upon your own persons, and upon all which is near and dear to you, wherefore abstain from the thoughts of the man, and let not so much as his name proceed out of your mouths. For know, if you will not obey us herein, which will be known, who, and what those men are, who refuse to conform unto us, we are resolved to prosecute them, as our duty is. He that doth hear, and obey us, may the blessing of God rest upon him. These are the words of those who seek your Peace and Good, having in Constantinople, on Sunday the fifth of the Month Sevat, underwrote their names.

Joam Tob son of Chananiah Ben-Jacar

Isaac Alnacagna.

Joseph Kazabi.

Manasseh Barndo.

Kalib son of Samuel.
Eliezer Castie. Eliezer Gherson. Joseph Accolien Eliezer Aluff.

During the time of all these transactions and passages at Constantinople, Smyrna, Abydos upon the Helespont, and Adrianople, the Jews leaving their Merchantly course, and advices, what prizes commodities bear, and matters of Traffick, stuffed their Letters for Italy and other parts, with nothing but wonders and 
miracles wrought by their false Messiah. As then when the Grand Signior sent to take him, he caused all the Messengers immediately to die, upon which other Janizaries being again sent, they all fell dead with a word only from his mouth; and being desired to revive them again, he immediately recall'd them to life; but of them only such who were true Turks, and not those who had denied that faith in which they were born, and had profest. After this they added, that he went voluntarily to prison, and though the gates were barr'd and shut with strong locks of Iron, yet that Sabatai was seen to walk through the streets with a numerous attendance, and when they laid Shackles on his neck and feet, they not only fell from him, but were converted into Gold, with which he gratified his true and faithful believers and disciples. Some Miracles also were reported of Nathan, that only at reading the name of any particular man or woman, he would immediately recount the story of his, or her life, their sins or defaults, and accordingly impose just correction and penance for them. These strong reports coming thus confidently into Italy and all parts, the Jews of Casel di 
Monferrato resolved to send three persons in behalf of their society, in the nature of extraordinary Legates to Smyrna, to make inquiry after the truth of all these rumours, who accordingly arriving in Smyrna, full of expectation and hopes, intending to present themselves with great Humility and Submission before their Messiah, and his Prophet Nathan, were entertain'd with the sad news, that Sabatai was turned Turk, by which information the Character of their Embassy in a manner ceasing, every one of them laying aside the formality of his function, endeavoured to lodge himself best to his own convenience. But that they might return to their brethren at home, with the certain particulars of the success of these affairs, they made a visit to the brother of Sabatai; who still continued to perswade them, that Sabatai was notwithstanding the true Messiah, that it was not he who had taken on him the habit and form of a Turk, but his Angel or Spirit, his body being ascended into Heaven, until God shall again see the season, and time to restore it, adding further, that an effect hereof they should see by the Prophet Nathan, certified now every day expected, who 
having wrought Miracles in many places, would also for their Consolation, reveal hidden secrets unto them, with which they should not only remain satisfied, but astonished. With this only hope of Nathan, these Legates were a little comforted, resolving to attend his arrival, in regard they had a Letter to consign into his hands, and according to their instructions, were to demand of him the grounds he had for his Prophesies, and what assurance he had, that he was divinely inspir'd, and how these things were reveal'd unto him, which he had committed to Paper, and dispersed to all parts of the World. At length Nathan arrives near Smyrna, on Friday the third of March, towards the Evening, and on Sunday these Legates made their visit to him: But Nathan, upon news of the success of his beloved Messiah, began to grow sullen and reserved; so that the Legates could scarce procure admittance to him ; all that they could do was to inform him, that they had a Letter to him from the brotherhood of Italy, and commission to confer with him concerning the foundation and authority he had for his prophesies; but Nathan refused to take the Letter, ordering Kain Abolafio a 
Chocham of the City of Smyrna to receive it ; so that the Legates returned ill contented, but yet with hopes at Nathans arrival at Smyrna to receive better satisfaction.

But whil'st Nathan intended to enter into Smyrna, the Chochams of Constantrnople, being before advised of his resolution to take a Journey into their parts, not knowing by which way he might come, sent their Letters and Orders to Smyrna, Prussia, and every way round, to hinder his passage, and interrupt his journey; fearing that things beginning now to compose, the Turks appeas'd for the former disorders, and the minds of the Jews in some manner settled, might be moved, and combustions burst out afresh, by the appearance of this new Impostor; And therefore dispatched this Letter as followeth.

To you who are the Shepherds of Israel, and Rulers, who reside for the great God of the whole World, in the City of Smyrna, which is Mother in Israel to her Princes, her Priests, her Judges, and especially to the perfect wise men and of great experience, may the Lord God cause you to live before him, and delight in the multitude of Peace, Amen, so be the will of the Lord. 
These our Letters are dispatched unto you, to let you understand, that in the place of your Holiness, we have heard that the learned man, which was in Gaza, called Nathan Benjamin, hath published Vain Doctrines, and made the World Tremble at his Words and Inventions; And that at this time we have received Advice, that this man some days since, departed from Gaza, and took his Journey by the way of Scanderone, intending there to Imbark for Smyrna, and thence to go to Constantinople, or Adrianople: And though it seem a strange thing unto us, that any Man should have a desire to throw himself into a place of Flames and Fire, and into the Sparks of Hell; notwithstanding we ought to fear, and suspect it; For the Feet of Man alwayes guide him to the worst; Wherefore we under-written do Advertise you, that this Man coming within the compass of your Jurisdiction, you give a stop to his Journey, and not suffer him to proceed farther, but presently to return back. For we would have you know, that at his coming, he will again begin to move those Tumults, which have been caused through the Imagination of a New Kingdom; And that Miracles are not to be Wrought every day.

God forbid that by his coming the People of God should be destroy'd in all places where they are, of which he will be the first, whose Blood be upon his own Head: For in this Conjuncture, every 
little Error or Fault is made Capital. You may remember the Danger of the first Combustion: And it is very probable that he will be an occasion of greater, which the Tongue is not able to express with Words. And therefore by Vertue of ours, and your own Authority, you are to hinder him from proceeding farther in his Journey, upon pain of all those Excommunications which our Law can Impose, and to force him to return back again, both he and his Company. But if he shall in any manner Oppose you, and Rebel against your Word, your Indeavours and Law are sufficient to hinder him, for it will be well for him and all Israel.

For the Love of God, let these Words enter into your Ears, since they are not vain things; for the Lives of all the Jews, and this also, consist therein. And the Lord God behold from Heaven, and have pitty upon his People Israel, Amen. So be his holy Will : Written by those who seek your Peace.

\section{Joam Tob, Son of Chanania Jacar}

Caleb Son of Chocham

Moise Benveniste,

Isaac Alce-nacagne, Samuel deceased.

Joseph Kazabi,

Samuel Acazsine, Moise Barndo. Elihezer Aluff. Jehoshuah Raphael. Benveniste.

By these means, Nathan being disappointed 
of his Wandring Progress, and partly ashamed of the event of things, contrary to his Prophesie, was resolved without entering Smyrna, to return again: however he obtained leave to visit the Sepulchre and there to receive Pardon of his Sins, but first washed himself in the Sea, in manner of Purification, and said his Tephilla, or Prayers, at the Fountain, called by us the Fountain Sancta Veneranda, which is near to the Cymetry of the Jews, and then departed for Xio, with two Companions, a Servant, and three Turks, to conduct him, without admitting the Legates to Audience, or answering the Letter which was sent him, from all the Communities of the Jews in Italy. And thus the Embassie of these Legates was concluded, and they returned from the place from whence they came, and the Jews again to their Wits, following their Trade of Merchandize and Brokage as formerly, with more quiet, and advantage, then the means of regaining their Possessions in the Land of promise. And thus ended this mad Phrensie amongst the Jews, which might have cost them dear, had not Sabatai Renounc't his Messiahship at the Feet of Mahomet. 
These matters were transacted in the years I665 \& 1666, since which Sabatai hath passed his time devoutly in the Ottoman Court, educated at the feet of the learned Gamaliel of the Turkish Law, that is Vanni Effendi, Preacher to the Seraglio, or as we may so term him Chaplain to the Sultan, one so literate as to be esteemed the Grand Oracle of their Religion, so precise and conceited of his own sanctity as a Pharisee, and so Superstitious that nothing seemed more to unhallow his worship than the touch or approach of a Christian. To this Master, Sabatai was a most docil Scholar, and profited, as we may Imagin beyond measure in the Turkish Doctrine, so that in exchange of such Impressions, Vanni thought it no disparagement from so great a Rabbine as his new Disciple, to learn something of the Jewish Rites, and rectify those crude notions he had conceived of the Mosaical Law ; in this manner Sabatai passed his days in the Turkish Court, as some time Moses did in that of the Egyptians, and perhaps in imitation of him, cast his eyes, often on the Afflictions of his brethren, of whom during his life he continued to profess himself a Deliverer, but with 
that care and caution of giving Scandal to the Turks, that he declared unless their nation became like him, that is, renounce the shaddows, and imperfect Elements of the Mosaical Law, which will be compleated by adherence to the Mahometan, and such other additions as his inspired wisdom should suggest, he should never be able to prevail with God for them, or conduct them to the holy Land of their forefathers : hereupon many Jezes flocked in, some as far as from Babylon, Jerusalem, and other remote places, and casting their caps on the ground in presence of the Grand Seignior, voluntarily professed themselves Mahometans; Sabatai himself by these Proselites gaining ground in the esteem of the Turks, had priviledg granted him to visit familiarly his Brethren, which he imployed in Circumcising their Children the 8th day, according to the Precept of Moses, preaching his new Doctrines by which he confirmed many in their faith of his being the Messiah, and startled all with the expectation of what these strange ways of Enthusiasm may produce but none durst publickly own him, lest they should displease the Turks, and the Jews, and incur the danger of Excom- 
munication from one, and the Gallows from the other.

Howsoever in January 1672 appeared another bold Impostor amongst the Jezes in Smyrna from Morea, as it was said, or not known from whence, who in despight of Sabatai, and his own Governors, pretended to be the Messiah; but with so petty and inconsiderable a Deluder as this, the Jerws thought to make quick work ; but being ashamed at first to bring another Messiah on the stage, by help of money they accused him of Adultery, and procured a sentence from the Kadi, condemning him to the Gallies; in order unto which, and in proof of his good behaviour, he remained some time in Prison, in which interim he found means to clear himself of that crime by open evidence to the contrary and had for the present escaped out of the power of the Synagogue had not their Authority and mony prevailed more than the friends and Disciple of this Impostor, so that he was still detained in Prison, and Sabatai Sevi continued in the house of Pharaoh or the Grand Seignior, where he remained till the year 1676 , and then died. 



\section{$\mathrm{X}$}

\section{THE PASSING OF THE PICTURESQUE}





\section{$\mathrm{X}$ \\ THE PASSING OF THE PICTURESQUE}

There has lately been issued under the auspices of the Foreign Office a publication of an interest which, at first sight, its title and appearance would scarcely seem to promise. It is the revised edition of a compilation bearing the not very enticing designation of "Treaties of Commerce and Navigation between Great Britain and Foreign Powers, wholly or partially in force on December $3 \mathrm{I}$, I9I2"; yet there lies amid its thousand odd pages a very world of humour, pathos, and picturesqueness. Chronologically, the earliest of its contents is a Treaty of Peace and Commerce concluded in 1654 between his Highness the Protector of the Commonwealth of England, Scotland, and Ireland and her 
250 PASSING OF PICTURESQUE $x$

Most Serene Royal Majesty the Queen of the Kingdom of Sweden; the latest, a protocol between Great Britain and Colombia, signed in August I9I2. Between 1654 and I9I2 there have been many changes in the status and methods of nations which this book mutely registers; the spacious days of Cromwell and Christina are succeeded by an age more efficient, perhaps, but sadly more prosaic. Powers once mighty yield pride of place to states then small, or non-existent ; the imaginative amenities of old-fashioned diplomatic correspondence make way for terseness and precision.

The book is a melancholy commentary on the decay of the picturesque in official phraseology. Let us glance at a treaty concluded in I 857 between Queen Victoria and "His Majesty, whose Standard is the Sun, the Sacred, the August, the Great Monarch, the absolute King of Kings of all the States of Persia." The plenipotentiaries of the high contracting parties were respectively Lord Cowley and "His Excellency the Abode of Greatness, the Favourite of the King, Ferokh Khan, Ameen Oolmoolk, the Great Ambassador 
of the Mighty State of Persia, the Possessor of the Royal Portrait, and of the Blue Cordon, the Bearer of the Diamond-studded Girdle, etc., etc., etc." One would give much to know the significance of the "etc., etc., etc." ; but mark the contrast with a later treaty signed in days when the Standard of the Sun had become dimmed, in an era of Belgian Treasury and Swedish gendarmerie. There is no word here of cordon bleu and Diamond-studded Girdle; the second Persian plenipotentiary is described tout court as "le Sieur Joseph Naus, Ministre d'Etat."

China provides us with no less striking a parallel. The Treaty of Nanking was signed in 1842 by Sir Henry Pottinger and "the High Commissioners Keying, a Member of the Imperial House, a Guardian of the Crown Prince, and General of the Garrison of Canton ; and Elepoo, of the Imperial Kindred, graciously permitted to wear the insignia of the first rank, and the distinction of a peacock's feather"; that of Tientsin in $185^{8}$ by Lord Elgin and "the High Commissioners Kweiliang, a Senior Chief Secretary of State, styled of the East Cabinet, Captain-General of the Plain White 
252 PASSING OF PICTURESQUE $x$

Banner of the Manchu Banner Force, Superintendent-General of the Administration of Criminal Law; and Hwashana, one of $\mathrm{His}$ Imperial Majesty's Expositors of the Classics, Manchu President of the Office for the regulation of the Civil Establishment, CaptainGeneral of the Bordered Blue Banner of the Chinese Banner Force, and Visitor of the Office of Interpretation." In these latter days the Chinese statesman wears a bowler hat rather than a peacock's feather; the counterpart of His Majesty's Expositor of the Classics has an American degree.

Still more significant is the preamble to the Turkish capitulations of 1675 , which runs as follows :

“Sultan Mehemed, may he live for ever!

"Let everything be observed in conformity to these Capitulations, and contrary thereto let nothing be done.

" The command, under the Sublime and lofty Signet, which imparts sublimity to every place, and under the imperial and noble Cypher, whose glory is renowned throughout all the world, by the Emperor and Conqueror of the Earth, 
achieved with the assistance of the Omnipotent, and by the especial grace of God, in this:

"We, who by Divine grace, assistance, will, and benevolence now are the King of Kings of the world, the Prince of Emperors of every age, the dispenser of Crowns to Monarchs, and the Champion Sultan Mehemed, Son of Sultan Ibrahim Chan, Son of Sultan Ahmed Chan, Son of Sultan Mahomed Chan, Son of Sultan Murad Chan, Son of Sultan Selim Chan, Son of Sultan Solyman Chan, Son of Sultan Selim Chan.

"Themost gloriousamongst the great Princes professing the faith of Jesus, and the most conspicuous amongst the Potentates of the nation of the Messiah, and the Umpire of public differences that exist between Christian nations, clothed with the mantle of magnificence and majesty, Charles the Second, King of England, Scotland, France, and Ireland (whose end terminate in bliss $\left.!^{1}\right)$, having sent an Ambassador to the Sublime Porte in the time of our grandfather Sultan Murad (whose tomb be ever resplendent !) of glorious memory and full of divine mercy and pity, with professions

1 A subtle aspiration to the effect that he may die a Moslem. 
of friendship, sincerity, devotion, partiality, and benevolence, and demanding that his subjects might be at liberty to come and go into these parts, which permission was granted to them in the reign of the Monarch aforesaid, in addition to various other special commands, to the end that on coming and going, either by land or sea, in their way, passage, and lodging, they might not experience any molestation or hindrance from any one.

"He represented, in the reign of our grandfather Sultan Mehemed Chan (whose tomb be ever resplendent !) to our just and overshadowing Porte, his cordial esteem, alliance, sincere friendship and partiality thereto. As such privilege, therefore, had been granted to the Kings and Sovereigns of France, Venice, and Poland, who profess the most profound devotion for our most eminent throne, and to others between whom and the Sublime Porte there exists a sincere amity and good understanding, so was the same, through friendship, in like manner, granted to the said King; and it was granted him that his subjects and their interpreters might safely and securely come and trade in these our sacred dominions. 
"The Capitulations of sublime dignity and our noble commands having been, through friendship, thus granted to the Kings aforesaid, and the Queen of the above-mentioned kingdom (sc. Queen Elizabeth) having heretofore also sent a noble personage with presents to this victorious Porte, which is the refuge and retreat of the Kings of the Kings of the world, the most exalted placed, and the asylum of the Emperors of the Universe (which gifts were graciously accepted), and she having earnestly implored the privilege in question, her entreaties were acceded to, and these our high commands conceded to her."

It is to be feared that the sublimity of the sublime and lofty Signet is less universally conspicuous in these days.

It is interesting to observe the gradual disappearance of religious invocations from the headings of European treaties. The earlier treaties were habitually concluded "in the Name of the Most Holy and Undivided Trinity." I can find no example here of that pious custom subsequent to a treaty of 1826 between George IV. and His Most Christian Majesty the King of France and Navarre, 
256 PASSING OF PICTURESQUE $x$

Charles X. How different is the attitude of the devout Siamese King, "incomprehensible to the head and brain, the sacred beauty of the royal palace, serene and infallible," who dutifully invokes "the powerful Lord, who is in possession of every good, and every dignity, the God Boodh, who dwells over every head in the city of the sacred and great Kingdom of Si-a-yoo-tha-ya!"

Much more there is in this fascinating volume: the proud and stately signature of former Kings of Spain, "Yo el rey, I the King"; the permission granted by the Sultan of Turkey to the Padishah of England to buy two cargoes of figs and raisins "for his own kitchen, at Smyrna, Salonica, or any other port of our sacred dominions, in fertile and abundant years, and not in times of dearth or scarcity"; the prohibition of United States vessels from touching " at St. Helena so long as Napoleon Buonaparte is there." But there is one document which has been omitted; or else my memory fails me and Great Britain was not a party to it. It is a Proclamation in which a Polynesian monarch announces to his subjects the ratification of an arrangement 
$x$ PASSING OF PICTURESQUE 257 with some European Power. After enjoining on his people the due observance of all its provisions, he concludes: "And if you fail to obey my commands, I shall be annoyed."

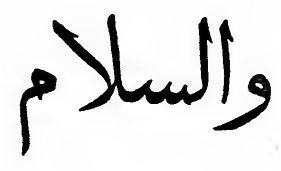





\section{THE FRINGE OF THE EAST}

A JOURNEY THROUGH

PAST AND PRESENT PROVINCES OF TURKEY

\section{Illustrated. 8vo. i $2 s$. net.}

THE TIMES. - " Undoubtedly the most sprightly book of travels of the last decade."

THE WESTMINSTER GAZETTE.- "Mr. Harry Charles Lukach has written, in worthy succession to Eothen, The Fringe of the East. Certainly no more important travel-book has appeared during the spring. . . . Compact of anecdote, history, personal experiences, classical quotations, Greek folk-songs-The Fringe of the East is a mine of treasure in studied disarray-it is also a model for travel-books."

THE DAILY NEWS.- " This is the best book of travel that has appeared for many a long day. Mr. Lukach has distinction of style, humour, fulness of knowledge, and sympathy-all the qualities necessary for making a memorable record."

THE SATURDAY REVIEW.-"The Fringe of the East is . . . admirably planned and written, vastly and agreeably informing, companionable; and revealing in its author, Mr..Lukach-who is also part-author of the workmanlike notebook on Cyprus, here, too, before us-a new, scholarly, and pleasant hand."

THE ATHENAUM.-."Mr. Lukach . . . showing a nice discrimination in his choice of material and a happy gift of graceful expression, combined with a true sense of humour, gives us an entirely delightful book of travel of the best type."

THE CONTEMPORARY REVIEW._-"It is an admirable book and will be widely read."

THE ENGLISH REVIEW.-"A really noteworthy book of travel, full of charm."

THE MANCHESTER GUARDIAN.- "It is a charmingly discursive volume, alike in its descriptions and its subjects, and the illustrations are admirable."

THE LEEDS MERCURY._- “Mr. Lukach has opened a stall, as it were, in some Oriental bazaar for the sole purpose of retailing rare and odd gems of Eastern lore picked up haphazard while following his avocation as tramp."

THE LIVERPOOL POST. - " Mr. Lukach's history is accurate, but is not a wearisome collection of facts; his knowledge is profound, but is not thrust prominently forward; his anecdotes are fresh and appropriate, his humour is subtle and telling."

LONDON: MACMILLAN AND CO., LTD. 


\section{SOME BOOKS OF TRAVEL.}

TRAVELS IN TURKEY. By Sir MARK Sykes, Bart, M.P. Illustrated. 8vo.

[In the Press.

ARABIA INFELIX. By G. WyMan Bury. Illustrated. 8 vo.

[In the Press.

THE LAND OF UZ. By AbDUllah Mansôr (G. Wyman BURY). Illustrated. 8vo. 8s. 6d. net.

THE GLORY OF THE SHIA WORLD. The Tale of a Pilgrimage. By Major P. M. SYKes, assisted by KHAN BAHADUR AHMAD DiN KHAN. Illustrated. 8vo. Ios. net.

PERSIA PAST AND PRESENT. By Prof. A. V. W. JACKSON. Illustrated. 8vo. I7s. net.

FROM CONSTANTINOPLE TO THE HOME OF OMAR KHAYYAM. Travels in Transcaucasia and Northern Persia. By Prof. A. V. W. JACKson. Illustrated. 8 vo. I 5s. net.

ACCIDENTS OF AN ANTIQUARY'S LIFE. By D. G. Hogarth. Illustrated. 8vo. 7s. 6d. net.

RUINS OF DESERT CATHAY. Personal Narrative of Explorations in Central Asia and Westernmost China. By Sir AUREL Stein. Illustrated. 2 vols. Royal 8vo. 42s. net.

A TRAMP'S SKETCHES. By Stephen Graham. Extra Crown 8vo. 5s. net.

WITH THE RUSSIAN PILGRIMS TO JERUSALEM. By STEPhen Graham. Illustrated. 8vo. 7s. 6d. net.

WITH POOR IMIMIGRANTS TO AMERICA. By STEPHEN GRAHAM. Illustrated. 8vo. 8s. 6d. net.

TRANS-HIMALAYA : Discoveries and Adventures in Tibet. By Sven Hedin. Illustrated. 8vo. Vols. I. and II. 3os. net. Vol. III. I5s. net.

OVERLAND TO INDIA. By Sven Hedin. Illustrated. 2 vols. 8vo. 3os. net.

LONDON : MACMILLAN AND CO., LTD. 



\section{RETURN TO: CIRCULATION DEPARTMENT 198 Main Stacks}

\begin{tabular}{cc|l|l}
\hline $\begin{array}{c}\text { LOAN PERIOD } \\
\text { Home Use }\end{array}$ & 1 & 2 & 3 \\
\hline & 4 & 5 & 6 \\
\hline
\end{tabular}

\section{ALL BOOKS MAY BE RECALLED AFTER 7 DAYS.}

Renewals and Recharges may be made 4 days prior to the due date. Books may be renewed by calling 642-3405.

\section{DUE AS STAMPED BELOW.}

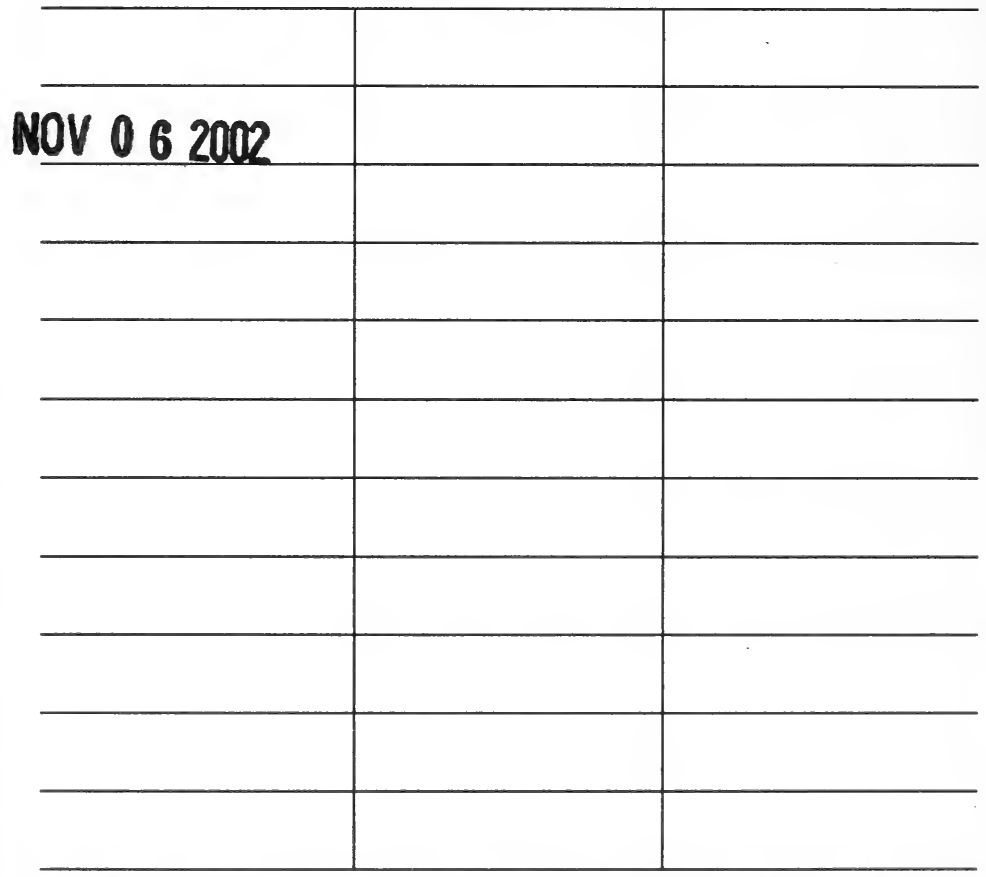

FORM NO. DD 6 50M 5-02
UNIVERSITY OF CALIFORNIA, BERKELEY Berkeley, California 94720-6000 


\section{YB 33950}

\section{U.C. BERKELEY LIBRARIES}

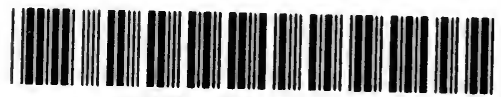

C004094749

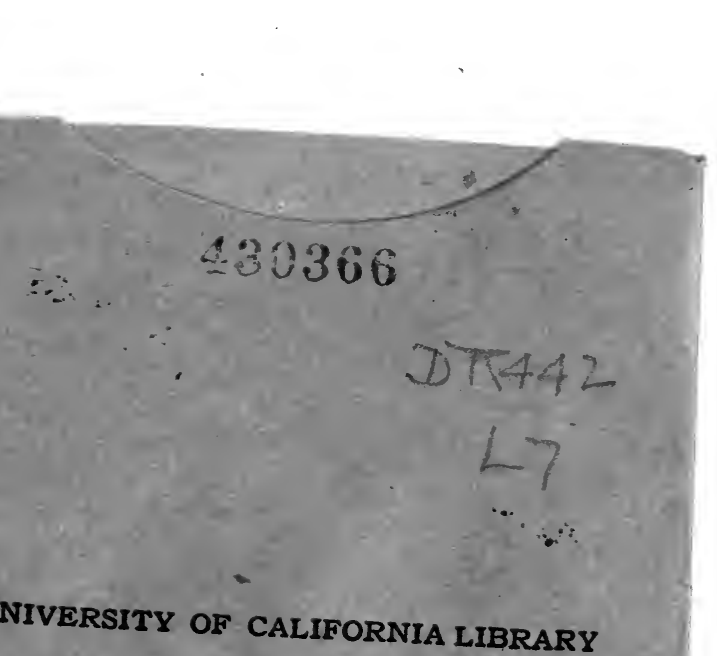


